F. A. W. MIQUEL, NETHERLANDS BOTANIST

\author{
F. A. STAFLEU \\ (Botanisch Museum en Herbarium, Utrecht) \\ (received November 1st, 1965) \\ GONTENTS
}

\title{
PART I
}

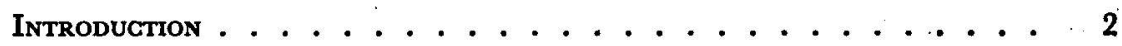

THE ROAD TO MEDICINE: YOUTH AND ADOLESCENGE . . . . . . . . 3

THE ROAD TO BOTANY: RoTtERDAM, 1835-1846 . . . . . . . . . . . 11

THE ROAD to THE ESTABLISHMENT: AMSTERDAM 1846-1859 . . . . . . . 22

Miquel and Mulder . . . . . . . . . . . 23

Taxonomy: from South America to the East Indies . . . . . . . . 24

The flora of the East and the Rijksherbarium. . . . . . . . . 28

Miquel and the "Institute" . . . . . . . . . . . . 32

Palaeobotany and Uilkens . . . . . . . . . . . . 36

Miquel and Cinchona. . . . . . . . . . . . . . 38

UTRECHT AND LEIDEN, A NEW COMBINATION: $1859-1871 \ldots \ldots \ldots$. . . . 40

Miquel's herbarium. . . . . . . . . . . . . . 42

The Rijksherbarium and the flora of Japan . . . . . . . 43

The last years . . . . . . . . . . . . 45

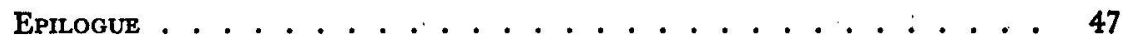

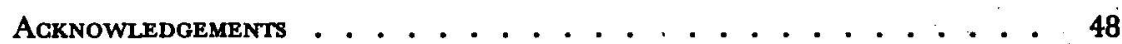

\section{PART II}

ANNOTATED LIST OF MLQUELS PUBLTCATIONS . . . . . . . . . ; 49

\section{APPENDICES}

THE DATES OF PUBLICATION OF THE PARTS OF Linnaea CONTAINING ARTICLES BY MrquzL ....................... 90

UNPUBLISHED SOURCES $\ldots \ldots \ldots \ldots \ldots \ldots \ldots \ldots$

Notes. . . . . . . . . . . . . . . . 92

References. . . . . . . . . . . . . . . 93 


\title{
PART I
}

\section{INTRODUCTION}

\author{
„,Over Miquel moet in velerlei \\ rigting worden gesproken", \\ G. J. MULDER
}

The University herbarium of Utrecht dates traditionally from the year 1816 when a collection of about 3000 plants was bought from the professor of botany M. van Geuns (1735-1817). It is possible that other collections of dried plants were already owned by the University or at any rate by the botanic garden, before that time, but nothing is known about this. The small van Geuns herbarium, which contained collections made by J. D. Hahn, M. W. Schwencke and S. J. van Geuns, among others, may therefore be taken as the starting-point of the herbarium of the later Botanical Museum.1)*) The period, however, was not one of great botanical activity at Utrecht and the botanist who succeeded van Geuns as professor of natural history and rural economy, Jan Kops, did little to increase the size of the collections. When C. A. Bergsma was appointed professor of botany in the faculty of natural sciences in 1835 nothing changed. Only when Miquel came to Utrecht, bringing his considerable personal herbarium, did scientific plant taxonomy get a chance. After his appointment as director of the Rijksherbarium in Leiden in 1862, Miquel was no longer allowed to have a private herbarium. His collections were taken over by the University of Utrecht and thus became the real foundation of the collection of the present institute. Miquel was succeeded by Rauwenhoff who was again scarcely interested in taxonomy, and it was not until Went and, somewhat later, Pulle, came on the scene that further development became possible.

Went and Pulle are still too close for a biographical assessment; Miquel, however, is sufficiently far away. In him we find a man not only of great local fame, but also of international standing as a plant taxonomist. In the year, therefore, in which the Utrecht Botanical Museum commemorates the 150th anniversary of the acquisition of its first herbarium together with the 40th anniversary of its association with J. Lanjouw, it seems appropriate to give a sketch of the life and works of the man who can be considered to be the founder of the Utrecht school of plant taxonomy. By the nature of his work, by building up the collections, and through his international relations Miquel started taxonomy at Utrecht.

Seen against the rich background of botany in the Netherlands during the 17 th and the early part of the 18th century, the picture of 19 th century botany is rather meagre in the era before Hugo de Vries and F.A.F.C. Went. Apart from Blume we encounter only Miquel as a man of high scientific standing and productivity. He had a broad outlook, a consuming interest in everything botanical, and, not least,

- The notes are given on p. 92-93; the numbers cited in parentheses refer to the annotated list of Miquel's publications on p. 49-89. 
an awe-inspiring output. In addition, Miquel was successful socially, and this, in combination with his scientific gifts, made him the undisputed leader in botany in the Netherlands in the middle of the century. Just as later with F. A. F. C. Went, practically nothing could happen without Miquel in the small botanical community of the Netherlands of his time. His influence in colonial matters (the Cinchona question), in university appointments, and in the affair of the Academy of Sciences was considerable. His recognition as a scientist steadily grew as is shown by repeated requests for collaboration in the great international enterprises of the time, such as the Prodromus of the de Candolles, the Flora brasiliensis, and some of the British reports on botanical expeditions.

Miquel's life can roughly be divided into four major periods: that of his youth and adolescence in the village of his birth and at Groningen University (1811-1833), the Rotterdam period (1835-1846) in which he was a lecturer at the local medical school, the period in Amsterdam (1846-1859) as a professor of botany at the Athenaeum, and the Utrecht period (1859-1871) as a professor of botany at the university, partly combined with the directorship of the Rijksherbarium at Leiden. In 1834 and 1835 Miquel was employed as a resident physician in an Amsterdam hospital. He was born on 24 October 1811 and died 23 January 1871.

No recent biographical account of Miquel exists. A few obituaries were published shortly after his death, one of which is of great importance as a contemporary testimony. From his early years in Rotterdam onward Miquel was associated with G. J. Mulder (18021880), the well-known militant scientist whose own field was organic chemistry, but who played an important rôle in shaping the scientific policy of government and universities alike in the middle part of the century. Mulder, 9 years older than Miquel, survived his friend and wrote a moving and profound appreciation in the Utrechtsche Studenten Almanak of 1872. Mulder and Miquel's friendship dates from the difficult early years of their career, spent in an uninspiring town far from the centres of culture. Mulder's story is colored by his sympathy, but also by his own outspoken criticism of certain new developments in a liberalized Holland. He did not want "to draw a picture of the eagle without including the rock on which he perched". He realized his limitations because of these personal associations and expressed the hope that others would write about other aspects of the life and work of his friend: ,over Miquel moet in velerlei rigting worden gesproken”. This motto should be the guiding principle of the present account.

\section{THE ROAD TO MEDICINE: YOUTH AND ADOLESCENGE}

The Miquel family came originally from Southwestern France, where they owned an estate, or perhaps just a large farm, in the neighbourhood of Cahors (Lot.). In the beginning of the eighteenth century, the estate was abandoned and the family settled first in Düsseldorff, and later in Münster, Westphalia (MuldER, 1872). 
Miquel's father was regional physician in the county of Lower Bentheim, stationed at Neuenhaus (Nienhuis in Dutch), a village less than five kilometers away from the Dutch-German border in the neighbourhood of Ootmarsum and Almelo. As a rural physician A. Th. Miquel seems to have been one of those benevolent and patriarchal key-figures around which life was centred in a time in which communications between that sparsely population moor region and the outside world were still rather primitive. Life in western Bentheim county was oriented towards the neighbouring part of the Netherlands, because the borderline was not such a severe division as in later times. There being no school of any importance in the village of Neuenhaus, Miquel senior educated his children ${ }^{2}$ ) himself, with the help of a private tutor. In the morning he made his rounds on horseback; the afternoons were given to teaching. Having had a thorough classical training himself, he held Latin and Greek in high regard and, according to Mulder, he resumed studying the classics for the sake of the children. "His Homerus and Cicero hidden in the saddle, on horseback, on his way to his patients, he prepared himself for the afternoon's lessons". MULDER and Matrues (1872) are our witnesses of the Miquel family. Mulder knew both parents and some of the brothers and sisters, partly from visits, but mainly from Miquel's own accounts; Matthes had also contacts with some of Miquel's teachers at Lingen. It seems clear that Miquel's preference for Latin, and the excellent way in which he handled the language, goes back to his early days in Neuenhaus under the guidance of his enthusiastic and dedicated father. According to Matthes, Miquel was kept at home for such a long time because of his generally weak constitution. To round off his secondary training he was sent to the "Gymnasium" at Lingen for one season (1828-1829). Lingen, a town thirty kilometers east of Neuenhaus, on the other side of the moors, had long been a regional centre of some importance, a market-place, a centre of light industry, and a centre of provincial learning. Miquel's "Gymnasium" was the descendent of a small university which had been converted into a secondary school in 1819 . The "Gymnasium" of those days was not unlike that still found in Germany and the Netherlands to-day, providing humanistic training with a heavy bias towards classical languages and history and preparing its pupils for the university.

The testimonies given by some of Miquel's teachers at Lingen, reported by Matthes, already point to some of his later characteristics: a great punctuality and orderliness, tremendous industry, and a remarkable proficiency in Latin and Greek.

In 1829 Miquel went to Groningen University, the nearest university of any size and standing. Goettingen was also considered; though somewhat further away, it would have had the dual advantages of having had a higher standard of learning, and of being German. The latter condition, however, was of lesser importance than may appear at first sight. Most of the lectures at Goettingen were given in German, but at the Dutch universities Latin was still in use in many of the courses. This, however, provided no difficulty for Miquel. Other language 
difficulties were hardly to be expected because of the local dialect of the border-region which must have been well-known to him. The reason why Goettingen was not chosen is not clear: Mulder hints at certain liberties taken by the students of that university which made the atmosphere less attractive. Groningen on the other hand was solid, old-fashioned, and-especially in the early years of the studymore like a school. Groningen must also have been better known to the family because of its proximity. Anyhow, Miquel turned Dutch and remained so all his life. According to several testimonies he spoke Dutch without the slightest accent in his later years; his written language is indistinguishable from that of others who had Dutch as their mother-tongue. True, it was some time before he published anything at all that was not in Latin, but this was in accordance with the custom of the time. Miquel considered himself a Dutchman, and was completely accepted as such by his environment. For his publications the language of his preference remained Latin. Apart from that he published and corresponded in French, German and Dutch. When submitting one of his earliest publications in German to the editor of Linnaea, Schlechtendal, Miquel requests him to correct the language and confesses that his German is insufficient. When corresponding with German colleagues, he never used the gothic script, although he had of course no difficulties in reading it.

Miquel went to Groningen to study medicine. It was possible to study botany, or at any rate natural sciences, at the Dutch state universities under the "law of 1815" governing higher education. The choice of medicine must therefore have been made deliberately, undoubtedly inspired by the example of the father.

The faculties of medicine and natural sciences at Groningen were certainly not impressively staffed in 1829 . The entire medical faculty of 1829-1830 consisted of four professors, who among them dealt with all branches of the science. One of them was the well-known W. Vrolik, ${ }^{3}$ ) just appointed, but who left Groningen for Amsterdam as early as 1831 . Miquel expresses his gratitude to Vrolik in the preface to his thesis; later he would become closely associated with him again in Amsterdam, at the Athenaeum and in the Academy of Sciences. In the year when Miquel took his degree, 1833, the medical faculty had been reduced to three professors: S. E. Stratingh-the only one also present in 1829, A. A. Sebastian, Miquel's promotor, - and I. Baart de la Faille.-The faculty of natural sciences was important for Miquel because medical students first had to obtain a primary degree in the natural sciences before being admitted to the medical study itself. This faculty had four professors: Seerp Brouwer for mathematics, S. Stratingh for chemistry, Th. van Swinderen for zoology, and H. C. van Hall for botany. Of these four men H. C. van Hall became Miquel's botanical mentor.

Herman Christiaan van Hall (1801-1874), only ten years older than Miquel, had been a professor of botany and rural economy at Groningen since 1826. He is kow best known as the author of the Flora Belgii septentrionalis (1825-1840), the earliest flora covering the 
present area of the Netherlands. In 1834 he published an Elementa botanices which went through three editions and which was also published in Dutch. In later years he published some popular books on botany, but apart from this his outward activities were not impressive. His best known pupils are Korthals, Miquel, and Holkema.

In order to understand Miquel's later lack of enthusiasm about his training at Groningen it is necessary to realize that the above faculties were, to say the least of it, of a very mediocre quality. The atmosphere, the cultural and scientific level, and the personalities of the Groningen University during the years of Miquel's apprenticeship have been described by HuIzINGA in his admirable history of Groningen University during the years 1814-1914 (1914). "Celebrities known outside the then so much more secluded circle in which the University worked, have not been produced by her [i.e. the University] in that period. In the general history of the natural sciences we find no Groningen names from that time. However, this does not mean that they could not have performed their cultural vocation...."

The cultural atmosphere of the Netherlands around the year 1830 can be characterized as the aftermath of that of the eighteenth century. The restoration after the Napoleonic wars started a period of calm, undisturbed but very slow development in a Europe relatively free from wars though not from plagues. Western Europe has rarely known a period like that of 1815-1870 in which its countries were not involved in major wars. No mean accomplishment of the Vienna Congress! The restoration, however, was not an immediate cause of progress. The industrial revolution made very slow progress in the Netherlands and became really noticeable only after 1840 . Minds were still full of the ideals of the Enlightenment: a humanitarian society of people of good will, optimistically placing full trust in the metaphysically determined law, order, beauty and harmony of the universe. The whole creation was seen as pointing towards usefulness for the benefit of mankind; improvement of minor deficiences was possible through education and the well-considered use of technical innovations. Nature was mainly something to be enjoyed, a beautiful pastime for clergymen and ladies of good education, an inspiration for artists. The natural sciences served ideals of harmonious beauty and usefulness but were not practised so much for the sake of themselves. We shall later see that Miquel, who grew up in a world dominated by these teleological learnings and in which "usefulness" was a prime requirement for human efforts, would be one of the first in his country to react and to stress the need of an independent and disinterested science, not primarily directed towards useful application for man. The Groningen group of natural scientists was very characteristic of this Indian summer of the Enlightenment.

The German "Naturphilosophie" of the early decades of the nineteenth century hardly influenced the minds of the more matter of fact Dutch scientists. The rather extreme, super-idealistic deductive reasonings of Schelling, Goethe (as far as his writing on the natular sciences is concerned), Nees von Esenbeck, to mention only a few, did 
not greatly affect the mind of the pragmatic Netherlands. Still, both movements, the teleological emphasis on utility (,nut" in Dutch) and the deductive "Uberschwenglichkeit" of the nature philosophy shared the background of the early romantic ideal of a harmonious, godordained order primarily directed towards man. The reaction in science against this spirit of the restoration would be a renewed effort towards independent, inductive research. The natural history cabinets with their rarities, queer monstrosities, and "beautiful" products of nature would still have to evolve towards the modern museums in which the collections are archives documenting scientific research. Th. van Swinderen, the zoologist at Groningen, and director of the cabinet of natural history, was still a representative of the late eighteenth century urge to collect for the sake of collecting and of illustrating the beauty and usefulness of creation. Van Hall, the botanist, and Miquel's teacher, taught botany as well as rural economy ${ }^{4}$ ) one of the queerest subjects of the period. Rural economy (oeconomia ruralis, landhuishoudkunde) was not given to the medical students or to the (few) natural scientists, but to the students going in for theology and law. In van Hall's time the latter group may already have been released from the obligation to "hear" rural economy in their first year; for the theological students it was still a "must". The ideal country clergyman was a man who would be able to converse intelligently with the farmers of his parish, who could act more or less as an agricultural consultant, and perhaps do some practical work himself in the garden in his -numerous-spare hours. Many of the "rural economists" were by origin clergyman. Van Hall, by training a medical man, was an exception and his assignment to teach this branch of learning was an indication that things were changing to some extent.

Both van Hall and Miquel would later be involved in the publication of a late edition of a book which was highly characteristic of the cultural climate of the Netherlands in the early part of the century: J. A. Uilkens' „De volmaaktheden van den Schepper in zijne schepselen beschouwd ter verheerlijking van God en tot bevordering van nuttige natuurkennis". Huizinga rightly points out that the title is a declaration of faith and a concise statement of the spiritual ideals of the period: "the perfections of the creator seen in his creatures, to the glory of God and to the promotion of useful knowledge of nature". It could not be better put. Whole generations grew up with Uilkens, this late follower of abbé Pluche and his Spectacle de la Nature of 1732 (cf. STAFLEU, 1963, p. 130). It may be said that Uilkens was a bit late as compared with Pluche and that he was perhaps a little more up to date. On the other hand there is no better illustration of Heinrich Heine's opinion on the state of affairs in their social, political, cultural, and scientific aspects in the Netherlands of the first half of the century of progress. When the world would come to an end, Heine said, he would go to Holland because everything always happened there later; - an unkind witticism, but perfectly justified for the first fifty years of academic life in the nineteenth century. After that things would change. Miquel would be involved in two entirely different ways in the great process of liberating 
science from its utilitarian and idealistic bonds: the affair of the academy of sciences, and the publication of the new edition in the fifties of Uilkens' work. Both will be discussed later in connection with the Amsterdam period of Miquel's life.

It is here not the place to analyse further the spiritual climate of Groningen University when Miquel received his medical training and his inauguration into botany. Some aspects, however, had such an influence on Miquel's character and later development that they must be briefly mentioned.

The use of Latin in many courses was characteristic of the Netherlands Universities. In France and Germany the teachers had already discovered that for direct contact with their pupils it was necessary to give their lectures in their mother tongue. Not so in the Netherlands. The French-influenced Universities in the Southern Netherlands soon grumbled against this requirement of the 1815 law, and they were able to do away with it almost immediately after the secession of Belgium in 1831. In Leiden, Groningen, and Utrecht, however, Latin still prevailed. For Miquel this may not have been a disadvantage, but for his fellow-students - as well as for his professors-the obligation to use Latin was often a great drawback. Especially in the natural sciences there was no guarantee whatsoever that the professor could express himself adequately. In the medical faculty most courses were already given in Dutch and so was the course in rural economy. Botany and mathematics, however, were still taught in Latin. Even the so-called "responsie-colleges" were conducted in Latin. The privatissima, however, saved the situation to some extent because they were conducted in Dutch-and for extra payment. The low standard of teaching, later mentioned by Miquel, was undoubtedly also in part a result of this remnant of the past. In seventeenth century Holland the universities drew many students from abroad, and Latin was their lingua franca. Now, however, this happy state of affairs had come to an end: the international university had become a rarity (Paris being one of the very few) and would be reintroduced only in the twentieth century with the development of English as the new "lingua franca".

Whether or not Miquel was influenced in his religious beliefs by what is known as the ,Groninger richting" which flourished during his time is unknown. The family was in all probability Roman catholic by tradition, and in one of his early letters to Miquel, van Hall mentions that a candidate for a post for which Miquel had unsuccessfully applied was a protestant. "His protestant belief may have made him the victor" he writes to Miquel in consolation.5) In June 1835in Amsterdam,-Miquel became a member of the ,,Remonstrantse gemeente", a liberal minded protestant group strongly represented in the North. It is quite possible that the Groningen theologists who were trying to liberalize the protestant churches had influenced Miquel to some extent, although they themselves did not represent this faction, but only a similar movement inside the Dutch Reformed Church. This, however, is purely conjectural. Miquel remained a confirmed believer in the Christian faith during his whole life, as is evident from his 
correspondence and - incidentally - from some of his writings. Here we touch again that key work for the understanding of Miquel's beliefs and scientific convictions, his 1855 contribution to the new „Uilkens".

Van Hall's botany was mainly morphological and floristic. Mulder states that Miquel had been attracted by plants from his early youth: "A childlike attachment to the kingdom of plants is a red line in Miquel's life, which one cannot let go without losing the line of his life." Miquel's first botanical publication was the treatment of the mosses and ferns for van Hall's Flora Belgii septentrionalis, published in 1832 (no. 1). The work was done in collaboration with the slightly older Michael Dassen (1809-1852) another physician with a great botanical interest.

Two successes of the young Miquel should be mentioned here: he obtained prizes for his answers to two prize-questions put by the Groningen and Leiden universities. These prize-questions were another characteristic remnant of the eighteenth century attitude towards science: didactic, benevolent, and useful. The answers were published (nos. 2, 4). The Groningen question dealt with the germination of plants, the Leiden one with the development and metamorphosis of the organs of plants. The answers show a great knowledge of the literature, no mean achievement at a University in which the library was in a chaotic state..$^{6}$ ) The personal association between Miquel and van Hall, however, was so close that he could make use of his professor's personal library for all his studies. The contact between student and professor could be very close in a university with less than 200 students, and this personal relationship often did much to counterbalance the disadvantages of the general practices of the university.

On 15 May 1833 Miquel defended his thesis Veterum de jecore merita (no. 3) (the merits of the classical writers with respect to the liver) in order to obtain his medical doctor's degree. The book was dedicated to his father and to H. C. van Hall. The subject had been suggested by his teacher Sebastian (pathology, anatomy, physiology) who evidently had no predilection for experimental medical research. However, the subject suited Miquel, whose good knowledge of the classics came to his aid. One other aspect of the subject, and of the way in which it was treated by Miquel, is its purely scientific character. Miquel's approach was factual and historical, as much as possible free from teleological implications and unsound conclusions with respect to the present state of the medical art. The anonymous reviewer in the Algemeene Konst- en Letterbode ${ }^{7}$ ) was quick to point out the great advantage of this independent, unbiased study, wholly unrelated to the ,stelselgeest" (i.e. the German Naturphilosophie) which still reigned in the realms of medicine. The study was a purely literary one, and from the medical point of view of little value. The question was "what did the classics know about the liver". Well, to quote Mulder, the answer was simple: "nothing". As an excercise, though, Miquel made the best of it and the way in which he approached his subject foreshadowed his development as an independent scientist. With apparent sympathy 
Miquel had quoted Sprengel at the end of his "reply" to the prizequestion on the germination of plants. Referring to the very many unsolved questions facing the scientist, and to the enormous gap between the exact knowledge of a few elementary processes and the understanding of organized life as a whole (we now call this the "organismal gap"), Sprengel-and Miquel-write "Sollte aber Der, welcher uns mit diesem Durste nach Erkenntnis erschuf, dieses unendliche Verlangen nicht einst zu stillen wissen?" This "unending longing" is a basic requirement of a scientist, and Miquel kept it all his life. He managed to reconcile his liberal but firm religious beliefs with his findings as a scientist, and the "unendliche Verlangen" resulted in a life deeply dedicated to science.

After having obtained his degree Miquel returned home and tried to find a suitable job. The degree was that of doctor of medicine. In the natural sciences Miquel had only his bachelor's degree, a general requirement for further medical study. In September 1850, on the occasion of the opening of the new University building at Groningen, Miquel was awarded an honorary doctor's degree in the natural sciences at his old university. This was the last service rendered to Miquel by $\mathrm{H}$. C. van Hall, at a time when the relations between the two men no longer had the cordiality of the earlier days. ${ }^{8}$ )

In the meantime, however, the medical degree was sufficient for Miquel. It does not seem to have occurred to him to find a non-medical position. For botanists there were hardly any places except for the few professorships at the institutions of advanced education. Even so, Miquel was immediately mentioned for the place of professor of botany at the Amsterdam Athenaeum, but only as number two after W. H. de Vriese. This botanist was only two years older than Miquel and held the position of lecturer in botany at the Rotterdam medical school. H. C. van Hall kept Miquel informed of the various happenings in "Holland". His letters to Miquel of that period, all preserved at Utrecht, throw an interesting light on the way these matters were handled. The Amsterdam authorities, however, facing one of their financial crises, were reluctant to appoint a new professor of botany and Miquel did not want to wait. Professor W. Vrolik, already at Amsterdam, offered him a position as a resident physician in the St. Pieters Buiten-gasthuis at Amsterdam. This "outer" hospital (outside the city limits, and used primarily to "cure" infectious and mental diseases) had the reputation of being an extremely dangerous place. Van Hall warned Miquel (2 October 1833) not to go there: three of his immediate predecessors had died. "In August and September there are yearly serious, often malicious fevers ...". Miquel accepted, notwithstanding the fevers: he wanted employment. A few months later de Vriese was appointed in Amsterdam (only as an extraordinary professor, to save money) and the Rotterdam position became vacant. De Vriese and van Hall urged Miquel to take it and to leave the unwholesome surroundings of that „moordhol" (cut-throat den) at the Overtoom.

Miquel stayed at the hospital for nearly two years. His first meeting 
with what would become one of his closest friends, G. J. Mulder, dates from those days. "At our first meeting I was already caught by that magic force of which Miquel had the secret.-However, in the same measure I was chagrined to see that almost walking corpse which he carried around, and which was prevented from becoming a corpse only by means of masses of quinine-powders ...". One thing transpires from this account: the almost charismatic personality of Miquel, which manifested itself by a great personal charm and tact. Even though taken almost entirely by his duties as a resident physician, Miquel continued his floristic hobby. He continued building up his herbarium, sought exchange relationships, and even got involved in an exchange of public letters in the Algemeene Konst- en Letterbode with C. A. Bergsma. This Utrecht professor of botany, the man whom Miquel would succeed in 1859, had published a short bibliography of the Netherlands flora which was so evidently incomplete that Miquel wrote a polite article against it. Bergsma, touchy because his image had suffered, showed irritation. Van Hall, Bergsma's brother-in-law, wrote to Miquel that he deplored this public show of mutual criticism and irritation: "the public has censured both of you in this case" (28 May 1834).

Certainly also thanks to the prompting by his friends, Miquel, in the end, reluctantly agreed to accept the Rotterdam position. He had been captured by the scientific possibilities of work at a hospital with so many interesting cases, and thought seriously of pursuing a scientific medical career. Whether he would have survived another few years of hospital-life is questionable. In all probability he had already contracted during those few months the serious liver disease which would plague him all his life, and which would finally fatally affect him at the age of 59 .

\section{The ROAD TO BOTANy: RotTERDAM, 1835-1846}

Nearly all the important centres of higher education in the Netherlands: Rotterdam, Deventer, Amsterdam, Utrecht, and Leiden played a part in Miquel's career. His appointment, in June $1835,{ }^{9}$ ) as „Lector in de Plantenkunde, de leer der Geneesmiddelen en Natuurlijke Geschiedenis" (lecturer in general and pharmaceutical botany) at the clinical school at Rotterdam makes it necessary to mention shortly the organization of higher education in the Netherlands between the laws of 1815 and 1876 . The secondary schools leading up to university education were (and in part still are) called Gymnasia. They had grown from the old grammar schools or Latin schools of pre-Napoleonic times, some of which, however, also remained in existence. In many instances the education at the former grammar schools did not go so far as that of the later gymnasia: hence the existence, in a number of towns, of so-called Athenaea. These Athenaea were institutions, giving an education not unlike that now given at liberal arts colleges in the United States. They bridged the gap between Latin School and 
university. The Amsterdam Athenaeum illustre provided the broadest education, but did not have the right to examine or to award doctor's degrees. For this it was always necessary to continue one's studies for a short time at one of the universities. The Amsterdam Athenaeum became a university in 1876, but all other Athenaea disappeared or had already disappeared when, in that same year the new law on higher education came into force. In Miquel's time there were only three universities, all financed by the state: Leiden (with financial priority, officially "number one"), Utrecht, prospering to such an extent that it soon came abreast with Leiden, and Groningen, the least conspicuous of the three, mainly because of its geographical isolation.

Medical training in the Netherlands took place at two levels: at the universities and at the clinical schools. The Rotterdam school, created with a number of others in 1827, was officially called the "Genees-, Heel-, Verlos- en Artsenijbereidkundige School". Similar schools existed in Alkmaar, Haarlem, Hoorn, and Middelburg; whereas in other places they were part of the Athenaea. These schools were designed to train town surgeons, country physicians, ship-surgeons, apothecaries, and midwives: the minor gods and goddesses of the medical profession. Except for Amsterdam, where they carried the title professor, the teachers at these institutions were called lecturers. The contemporary criticism of this second rate medical training was severe and all schools disappeared in the course of the century. For Miquel Rotterdam was attractive because of the well-developed botanic garden which he would have at his disposal. The salary was such (fl. 500.- a year) that only a practising physician in the town itself could afford to fill the position as a by-job. W. H. de Vriese, Miquel's predecessor, had been such a practising physician, and Miquel also started a medical practice. One of the immediate results of this practice was that he contracted exanthematic typhus in a serious degree, which brought him, in 1835, for the first time to the brink of the grave.

Miquel's scientific development could now really begin. At first he published some historical studies such as that on Dodoens (no. 6) and the erudite, many-sided Tentamen florae Homericae (no. 7), but these dated from his stay in Amsterdam. In Rotterdam, happy to be in daily contact with a reasonably well stocked botanic garden, Miquel gradually switched over to morphological, physiological, and taxonomic studies based on living plants. In addition, however, there were some more floristic and geobotanical studies. Miquel prepared the Algae for van Hall's Flora, was for some time editor and author of Kops' Flora Batava (no. 47), and published two phytogeographical surveys of the Dutch flora (nos. 15 and 26). In the Disquisito geographico-botanica de plantarum regni batavi distributione of 1837 he shows himself a worthy follower of Alexander von Humboldt by his climatological and general ecological remarks. In the Prolegomena to this publication he discusses "the Netherlands as an environment for plant life", a hundred years before the book carrying that title was distributed among the delegates at the Amsterdam Botanical Congress. A review is given of the geognostic characters of the Dutch soil, of the annual variation of the 
temperature, humidity, and rainfall. Some of the meteorological details were provided by Miquel's Rotterdam friend W. Wenckebach. The Prolegomena, admittedly stimulated by von Humboldt's Distributio geographica Plantarum, must be regarded as the beginning of synecological research in the Netherlands. After this introduction Miquel treats the great physiognomic formations and the general character of the vegetation of the Netherlands. The flora is characterized statistically by comparing the percentages of representatives of various families. The time had not yet come for an analysis of ecological groups. In this statistical comparison of the Dutch flora with that of other countries Miquel emphasizes the different state of knowledge of the floras concerned, a circumstance which tends to lower the value of his comparisons. A very interesting remark is that on the necessity to distinguish clearly between native and introduced species in phytogeographical studies. As a pioneer study the Disquisitio shows perhaps many shortcomings. Miquel, however, was evidently the first to take the plant-geography of the Netherlands seriously.

It is impossible to discuss here the stream of publications issued in the years 1837-1839. When it is realized that in addition to his courses at the clinical school, Miquel had the care of a botanic garden and a medical practice as well, his productivity seems unbelievable. However, this would from now on be true of almost every year of his life. The grand total of 296 publications issued in the course of forty years is impressive, especially when the major books and serials are taken into consideration. The activities around 1838 do not yet show a definite direction. It is as if Miquel, enjoying his freedom as a scientist, and enthusiastically discovering interesting problems in the entire field of botany, tries out which of the disciplines to pursue. Floristics and plant geography have already been mentioned. On pharmaceutical botany there are two books (nos. 11 and 44), in morphology his interest goes towards the Cactaceae and the Cycadaceae. The latter family would be one of his special fields during his whole life: an up-to-date survey of the knowledge of this fascinating group would be among his very last publications. In plant physiology-a coming science in the eighteenthirties-Miquel was intrigued by that old hobby-horse of teleology Mimosa pudica (36). His analysis and explanations may no longer stand, but his approach is purely inductive, without bias or preconceived notions. The same is true of his experiments on the influence of light on water exhalation (35) and on the action of poisonous substances on plants (39). During these years of gestation we can follow in Miquel's writings his evolution as a scientist. Almost overwhelmed by the great possibilities of research in all directions, he tries to follow two main lines: first that of independent observation and experimentation, second that of integrating the results of his morphological studies in his systematic work.

Miquel arrived in Rotterdam as a floristic systematist. In a few years, thanks also to a thorough study of the literature, we see him evolve towards an all-round taxonomist who seeks to integrate his findings in all fields to understand the group with which he works. 
When, in 1840, his monograph of the genus Melocactus appears (62) we know that Miquel has found his way. From now on his efforts will be towards synthetic taxonomy. A monograph of the Cycadaceae soon follows (66), but the main result of that early period is an early classic of one of the most difficult groups: his Systema Piperacearum of 1843/1844 (78). This monograph, dedicated to Benjamin Delessert, was written along "modern" lines. The material from several important European collections had been received on loan. The richest single collection on which the work was based was that from Benjamin Delessert at Paris, but other valuable loans were obtained from the Paris Museum, from Berlin and Leiden, and from the private collections of Nees van Esenbeck (who had Wallich's Piperaceae on loan), Kunze in Leipzig, Meisner in Basel, and de Vriese in Amsterdam. The family proved to be a sizeable one: 563 species. The monograph was very favorably received: Sir William Jackson Hooker and Schlechtendal published approving reviews. Shortly after the publication of the Systema his atlas of drawings by Ver Huell appeared, conspicuous for the high botanical value of the plates in addition to their great beauty. Later Miquel worked on many special collections of Piperaceae, but when at last Alphonse de Candolle had progressed so far with the Prodromus that the Piperaceae would have to be worked up, Miquel no longer had the time to undertake it and the job was, reluctantly, left to the young Casimir de Candolle. Although Miquel was not always equally critical in describing new species, especially in his Amsterdam years when he was overloaded with other obligations, his attitude was on the whole conservative. This is especially evident from his work on Melocactus, which, according to VAlckenier Suringar (1903), remained a standard for a long time in a group which was usually on the move " . . sehr fleissig hat man die Arten bestimmt, und Mancher hat sich die Freude machen konnen, sein mihi auf jeder Seite der Cactusbücher zu erblicken. Aber gewiss wird Manchem die unbarmherzige Wahrheit den Spass verderben, denn schon jetzt beginnt man einzusehen dass manche der sogenannten Species zu Altersverschiedenheiten, LocalVarietäten u. dgl. herabgesetzt werden müssen . . ." Notwithstanding this early warning, little seems to have changed. There are still some to-day who see their mihi on every page of the cactus books. In the course of these few years Miquel had already succeeded in building up a lively correspondence with prominent taxonomists abroad. The steadily increasing facilities to travel had brought him many visitors: Adolphe Brongniart, Decaisne, W.J. Hooker, to mention only a few of the most conspicuous. The steamboats appeared in great numbers on the rivers and on the seas around Europe. The first railroads were being built and it became increasingly simpler to obtain big loans of herbarium specimens. Whereas in the eighteen twenties and early thirties it was still practically always necessary for taxonomists to travel themselves to the great collections, especially in London, Paris, and Geneva, curators now gradually lost their reluctance to part with their collections in order to have them studied. William Jackson Hooker and Benjamin Delessert were, in this respect as in others, 
leading the way. Miquel could still write his monograph of Melocactus mainly by using the living material from his botanic garden, carefully brought together by exchange of living plants with similar centers. It is clear, however, that the Systema Piperacearum could not have been written without the help of important loans from Paris and London, the more so since Miquel could not, and perhaps was not even eager, to travel himself.

Another fortunate development for Miquel was his early association with the Dutch magistrate at Paramaribo in Suriname, Hendrik Charles Focke (1802-1858), who sent him important collections of dried and living material from 1835 onward. Since the correspondence between Focke and Miquel is not among the letters at Utrecht and apparently not readily available elsewhere, if extant at all, we do not know with certainty how Miquel and Focke became acquainted. It is possible that one of Miquel's important Rotterdam contacts, Cornelis Dalen, had something to do with it. Dalen was a physician who had a cabinet of natural history (ENGEL, 1939) which contained mainly insects and shells. He also had some relation to the Rotterdam botanic garden probably mainly because of his ample means and interest in natural history. Dalen provided plants for the garden and may even have had a garden himself. He obviously had several foreign contacts.

The Focke collections were an early inspiration to Miquel to work with Suriname material: apart from the living plants he found at Rotterdam they were in all probability his real introduction to the flora of the tropics. The discovery that there was a whole field of research wide open before him in the flora of Suriname must have been one of the most important formative factors in his scientific development. The first publication on Suriname plants is as early as 1840 in his Commentarii phytographici (49). In the second fascicle there is a separate article on Melastomaceae surinamenses selectae, based on Focke material. This was only the first of an almost uninterrupted series of publications on Suriname plants, culminating in that forerunner of the Flora of Suriname, Miquel's Stirpes surinamenses selectae of 1851 (143). In later years Miquel also received other collections from Suriname (Kappler, Hostmann, Splitgerber) which were partly incorporated in his private herbarium, thus making it the ideal basis for the more comprehensive study of the flora undertaken by Pulle in 1904. In his early years in Rotterdam, therefore, Miquel laid the foundation, by acquiring the Focke collections and by publishing on them, for the future main line of research of the Utrecht institute. For the moment, however, Utrecht was not yet even in sight; C. A. Bergsma was still going strong although doing precious little. Miquel's relations with Utrecht were not of the most cordial. Bergsma had probably never forgiven Miquel's juvenile criticism of one of his rare botanical publications. In his letter to Schlechtendal of 7 March 1838, Miquel writes of Bergsma: "Der Utrechter Garten hebt sich etwas seitdem B. dabei angestellt ist, der wenigstens die Pfl.=zahl [Pflanzenzahl] vermehrt. Die Botanik ist aber sein Fach nicht, da er früher in Belgien Professor der technischen Chemie war, von da verjagt [after the 
secession], als Prof. extraord. in Utrecht angestellt wurde, und als Prof. Nat. Kops emeritus ward, stellte die Regierung ihn an seine Stelle, welcher für diese wieder eine Pension ausgewann. Seine Stellung ist jedoch nicht angenehm, da er seines Charakters wegen von niemand geliebt ist." After the secession of Belgium in 1831 the northern professors at southern Netherlands Universities had to leave Belgium but remained by guarantee in the service of the state.10) They were distributed over various universities as "extraordinary" professors receiving only a guaranteed pension and hence costing nothing extra. The events in Belgium had resulted in a credit-squeeze for all Universities and a subsequent economy campaign. This development had also been responsible for the delay in the appointment of $W$. $H$. de Vriese at Amsterdam. Indirectly, therefore, this same economy-drive had brought Miquel to the Buitengasthuis.

Another valuable contact was developed by Miquel in his relations with Korthals, Blume, and the Rijksherbarium at Leiden. Here Miquel found another source of tropical material, as is evident from several of his publications and especially from the Systema Piperacearum. Miquel dedicated his Leerboek tot de kennis der Artsenijgewassen of 1838 (44) to Blume; in that same year Blume published a genus Miquelia and sent the manuscript description to Miquel. ${ }^{11}$ ) The relations were cordial, Miquel profited greatly by Blume's profound knowledge of the Malesian flora and in general by his critical and independent scientific attitude. In later years, when Blume became more isolated and reluctant to part with the collections which had been entrusted to his care, the relations between Miquel and Blume would lose all cordiality; Miquel, however, always held Blume's achievements as a scientist in high regard.

The year 1838 showed in several ways that the intellectual industry of Miquel had not passed unnoticed.

In April Miquel was elected a member of the Leopoldina, in September a member of the Provinciaal Utrechtsch Genootschap; in November he received a special present from the king in recognition of his meritorious publications in the form of copies of Blume's Flora Favae and Rumphia. On 17 November 1838 Miquel was appointed correspondent of the ,Instituut", the royal academy of sciences. In September 1839 Miquel was appointed (without having any previous knowledge of it) lecturer in botany and chemistry at the Athenaeum in Deventer. ${ }^{12}$ ) The position was designed to provide training for medical students: the Deventer Athenaeum had a medical faculty in status not unlike that of the clinical schools. In standing, and in salary undoubtedly, the appointment meant a promotion. Not for Miquel though. The municipal Deventer Athenaeum had no botanic garden and was furthermore definitely past its prime. The school, dating from 1630, had known great times, especially in its early days when Jacobus Revius, the famous poet and theologian, had put it on its feet. After its degradation to a secondary school during the Napoleonic time, the Athenaeum was reinstated in 1815, but it never regained its old glory. Already in Miquel's days it led a difficult life. The Groningen faculty, which had 
been instrumental in bringing about the appointment ("call" would be a more appropriate term) had certainly the best intentions towards Miquel, but had not realized that with all the difficulties of hard work and small pay, Miquel's development as a scientist was due mainly to the Rotterdam botanic garden and the contacts that he could make through it. Miquel did not hesitate and declined the invitation almost immediately.

Motives other than scientific may not have been foreign to his decision. Miquel had found close friends in Rotterdam in G. J. Mulder, his colleague at the clinical school, J. van Geuns, a physician known to him from his Groningen days, and especially W. Wenckebach, mathematician and physicist, co-editor with Miquel and Mulder of the Bulletin des sciences physiques et naturelles en Néerlande. This short-lived periodical (only three volumes were published, 1838-1840, cf. no. 24) was meant to make the results of research in the Netherlands known abroad and contained original publications as well as translations or abstracts of articles originally published in Dutch. We find here the first intimation of another of Miquel's later characteristics: his international outlook. An association of another kind was that with the banker's family Madry-through Mulder again-and especially with one of the daughters of the house, Catharina Elisabeth, whom Miquel married in 1840 .

With his marriage Miquel's life changed considerably for the better. Hitherto he had lived in a kind of "mansarde", romantically and bohemian, but perhaps not very comfortably, and practically always short of money. After his marriage Miquel could live more comfortably. Though poverty sometimes breeds artists and scientists, it is a good thing that a reasonable affluence does not always have a contrary effect. We find no trace of relaxation: the productivity continued.

The years 1840-1846 show a steady growth of scientific status and a definitive choice of direction. Taxonomy in its widest sense, supported especially by morphological and anatomical research, and mainly directed towards tropical groups, would henceforth be Miquel's vocation. The international contacts proliferate and so do the publications in journals abroad. The main preparatory work on the flora of Suriname falls in these years. The great monograph of the Piperaceae is finished. Morphological, anatomical, and taxonomic studies of the Cycadeae are still prominent. This group puzzled Miquel because of its peculiar mode of fertilization, then still very much discussed and unsettled.

Miquel's growing self-confidence, as well as his development towards a scientific attitude wholly at variance with the narrowly utilitarian teachings received at Groningen, is well shown by his publication of 1842 (67) on the botanical education of medical and pharmaceutical practitioners. As a medical student at Groningen he had apparently felt the shortcomings of the botanical training, and as a lecturer in botany at a medical school he became even more aware of the legislative and educational shortcomings in his field. The law prescribed the teaching of the "elements" of botany to medical 
students. A complicating issue was that his Groningen teacher H. C. van Hall had just published an Elementa botanices so that Miquel's criticism could be read in two different ways. His publication did not fail, therefore, to sollicit a rather animated response from his former teacher. Miquel's summing up of the reasons why botanical teaching was in such a sad state in the Netherlands are worth quoting in full. The first is self-evident and has little to do with his convictions as a scientist, but the second in his profession of faith. The reasons then, in Miquel's words, must [be found]:

„1. inzonderheid ook gezocht worden in de slechte ontwikkeling der jonge lieden hier te Lande, voordat zij tot de akademische studie komen, en

2. in het ontbreken van de ware wetenschappelijkheid; liefde voor de Wetenschap, welke alleen de echte prikkel tot hoogere ontwikkeling is, moet de plaats vervangen van dien ellendigen, alles goede uitdoovenden geest, om de Wetenschappen slechts als een middel tot maatschappelijk bestaan te gebruiken, waaronder veelal niets anders verstaan wordt dan het bezit van de materiële behoeften des levens, zonder hooger en edeler bedoelingen voor zich en zijnen evennaaste."

[1. ... especially also in the poor preliminary education of the young men in this country, before they start their academic studies, and

2. in the absence of a true scientific character; love for Science, which alone is the true stimulus to higher education, must take the place of that rotten spirit which kills all good, to use the sciences only as a means for social existence, which word usually stands for nothing else but the possession of the material needs of life, without higher and nobler intentions for oneself and his fellow-man.]

This statement embodies Miquel's revolution against the selfsatisfied spirit of the early decades of his century. The narrowly utilitarian attitude which was so characteristic of the degenerated aftermath of the "Enlightenment" (the word had become ironical) is rejected. The revolution was towards science for the sake of sciencescience not subservient to society, not primarily an instrument for material improvement, but an independent realm of the human mind. Ultimately this independence would serve humanity, but at a much higher level, and also much more effectively. This revolution, embodied here in Miquel, is especially clear in Germany and Holland. In Germany the struggle in the natural sciences had a conspicuous mentality to defeat in the "Naturphilosophie". "Ich selbst halte nicht auf s.g. Naturphilosophie" writes Miquel to Schlechtendal (Apr. 1844). Schleiden, Naegeli, and von Mohl were in full swing to change the bases of botanical science. The first edition of Schleiden's much debated work Grundzüge der wissenschaftlichen Botanik appeared in the same year (1842) as Miquel's more modest essay. Miquel held Schleiden in very high regard and often quoted from his works although he did not always approve of his polemic utterances. The second edition 
of Schleiden's book (1845-1846) carried an extra title which was a slogan: Die Botanik als inductive Wissenschaft behandelt. It is the time of the great development of physiological work, made possible by rapidly improving technology thanks to the industrial development. The better communications between scientists and the increasing mutual visits and international meetings have already been referred to. All these factors co-operate to awake the scientific world from its postNapoleonic lethargy.

"It was also the time in which the German mind, not yet captivated by a military power-policy, the mind as it expressed itself through the poets, the philosophers, through music and science, sounded stronger and finer every day, not in the political European concert, but in the spiritual concert of the civilised world. For a mutual penetration of French and German culture, circumstances have never been as favorable as during this aftermath of the Romantic movement" (Huizinga, 1949). Miquel was sharply aware of this and enthusiastically turned towards German culture. This orientation would persist and it can be imagined what impression the for him so unexpected outburst of military power-politics of 1870 made on Miquel in the last months of his life.

Developments around the Netherlands were faster than at home but if they did not lead, the Dutch at any rate followed in the wake of the great events. The changes in the scientific worlds of France and England had been more gradual, although in France a short period of post-Congress sleepiness can be detected, especially during the unchallenged reign of the otherwise eminent but purely descriptive Cuvier. It is, however, sufficient to mention the names Auguste Comte and Robert Brown to illustrate the coming of a new age also in these countries. The years between 1835 and 1842 had seen the development of great portions of the continental railways-system, the appearance on the seas of the regular steam-packets, the construction and early use of the electromagnetic telegraph, the first attempts at photography, the famous "universal microscope" of C. L. Chevalier. An exciting time to live in for people who were aware of these developments. No wonder that Miquel-keenly interested and wellinformed-was critical of the old-fashioned way in which botany was taught in the Netherlands. Science, independently developed, would benefit medicine. In botany this meant physiology, phytochemistry, anatomy, morphology, and the basic tenets of synthetic taxonomy, but not the learning by heart of dictated courses on "some native plants from the environs of Leiden and Groningen". A physician had to receive a basic scientific training in order to make him observe keenly at the bedside, to remain aware of the developments of his own science, and not to trust outdated "materies medica". This subject "can only obtain a place among the sciences if based on the strictly scientific principles of chemistry, botany, and physiology".

Van Hall took personal offense, although there was hardly any reason to do so. Miquel's essay was expressed in general terms, but of course whom the cap fits, let him wear it. The cap fitted university 
botanists too well, whether it was Reinwardt in Leiden ("become an almost complete nonentity", Backer), Bergsma in Utrecht (not even a botanist), or van Hall in Groningen (elementary morphology, floristics, and rural economy). An exception was the still relatively young W. H. de Vriese in Amsterdam, whose eyes were wide open and who fully realized his social duty as a scientist with a task to educate. The picture of the botanical Netherlands in those days is not rich. The only scientist of really high standing was the taxonomist Blume, at the Rijksherbarium (not connected with the University). Besides him there was the erudite and philosophical Korthals, living in seclusion, and the botanical traveller Ph. von Siebold, author of the Flora japonica. Also abroad the opinion of Dutch botanical science was not very high, though rarely outspoken. Hugo von Mohl, in a very favourable review of von Siebold's Flora Japonica in the Botanische Zeitung of 6 January 1843 wrote "Es ist recht erfreulich, Werke von klassischem Werth, wie das Vorliegende, in einem Lande erscheinen zu sehen, wo es mit der Wissenschaftlichkeit schlecht bestellt ist und die Kritik sich zu einer Hohe erhoben hat, dass z.B. ein Elementar Handbuch der Botanik, worin aus Sprengel anatomische Abbildungen copiert sind, des höchsten Lobes würdig gehalten wird ...". Siebold's well-executed work made slow progress: Miquel would later edit the last and posthumous part of it.

Miquel's contacts with Germany in these years were mainly with Schlechtendal at Halle, the editor of Linnaea, Gustav Kunze at Leipzig, the two Nees von Esenbeck's and Treviranus at Bonn, and Martius in Munich. His most important French correspondents were Adolphe Brongniart, Adrien de Jussieu, and Mirbel. In England contact was established first with the young J. D. Hooker-who visited Miquel in Rotterdam in 1845-and later through the son with the father, Sir William Jackson Hooker.

The correspondence with the Nees ab Esenbeck's has a special flavor. Christian Gottfried, the elder of the two brothers, president of the famous Kaiserlich Leopoldinisch-Carolinische Akademie der Naturforscher, had proposed Miquel for membership. All members in the society had a "cognomen" and Nees asked his younger brother Theodor Friedrich (1787-1837) in 1837 to find one for Miquel. Th. F. Nees and Miquel were in close correspondence that yearmainly on pharmaceutical botany-and Miquel was asked to make a suggestion. On 12 Dec. 1837, before the choice had been made, the younger Nees died and Miquel decided to adopt his name.

Miquel's relations with the elder Nees, in Breslau, were also very cordial, although he certainly did not approve of the latter's "Naturphilosophische Ausschweifungen". When Nees, in later years, lost his position and lived in poverty, it was Miquel who organized a drive for financial help in the Netherlands.

One other association from these years should be mentioned: that with Q. M. R. Ver Huell (1787-1860). Ver Huell was a military man who had travelled in the Dutch East and West Indies. In Miquel's Rotterdam period he became "Commander of the mouths of the 
Meuse". As a skilled amateur botanical artist he provided illustrations for almost all of Miquel's works. One of his finest achievements was the set of plates of Piperaceae published as Illustrationes piperacearum (110). Little is known about the personal association of the two men: the few letters preserved at Utrecht are rather formal. Ver Huell illustrated works of other Dutch botanists as well and made some delightful drawings and paintings of his own Malesian collections. ${ }^{13}$ )

Joseph Dalton Hooker and Miquel remained in close contact ever since the former's visit to Miquel in the spring of 1845 . Both were engaged that year in improving their position: Hooker was trying to obtain the chair of professor of botany in Edinburgh and asked Miquel for a testimonial. The position was desirable because of the very high salary which it carried. Miquel himself hoped to succeed the aged Reinwardt in a similar position at Leiden. On 21 Oct. 1845 Hooker wrote to Miquel that he had lost the election at Edinburgh. "It was gained by Dr Balfour of Glasgow, who was very intimately acquainted with the councillors, none of whom were known to me. They did not regard my testimonials..." Miquel was equally unsuccessful: the nominee for the Leiden chair was, as had been the case in 1834 for Amsterdam, W. H. de Vriese, a Leiden man. According to a later statement by Miquel (see below) this appointment had also not been free from "social" influences. Hooker comments: "Thus my dear friend has this year seen both of us beaten in our views towards lucrative botanical appointments! well n'importe, we shall work all the better for being poorer and let us hope that science will be the gainer". There was no doubt that science wàs the gainer, in both cases. Hooker's subsequent travels, which made him into one of the greatest phytogeographers and taxonomists of his age, would not have taken place from Edinburgh. And Miquel? De Vriese had vacated Amsterdam, so why not follow him again and try to come back to Amsterdam, that lively center of Dutch culture, with its excellent Athenaeum, with the academy of sciences, all the old friends from Groningen and from his days in the Buitengasthuis and-not leastwith the richest botanical garden of the Netherlands? It took some time. Miquel even moved to a larger house on the Wijnhaven in Rotterdam: "I regret [writes Hooker in the same letter] that I cannot think of you in your little studio up the escalier, where I often call you to my mind, with your most excellent cheroot".

The year 1846 at last brought the decision. It was another momentous year for Miquel. The appointment to the Amsterdam chair came early in the year, and in May he was elected a regular member of the academy of sciences (the "Instituut"). That same year he sent his memoir on the cultivation of Cinchona in the East to the governement, a memoir that would tip the balance in favour of the introduction of this plant on Java. ${ }^{14}$ )

All these happenings inaugurated the change from the "Privatgelehrter", the self-made scientist who wrote his best work in the evening hours because of a pressing daily routine, to the established scientist who had a greater rôle to play in the scientific development of 
his country. No medical practice anymore; some affluence and plenty of opportunity for the development of his many gifts. Miquel took the challenge and made the most of it.

The road to the estabishment: Amsterdam 1846-1859

The Amsterdam appointment came to Miquel as a relief. The medical practice weighed heavily on his mind and body because of his constant desire to spend more time on his scientific research. He had several periods of severe illness behind him, and was again in full swing. The collections from Suriname came in regularly: from his oldest associate Focke, from his Amsterdam friend Splitgerber, and also from Hostmann and Kappler through the intermediacy of J. D. Hooker and Hohenacker. ${ }^{15}$ ) The latter asked Miquel to name his series of Suriname exsiccatae in exchange for a set. Two more monographs were in preparation, one on Casuarina, another on Ficus, and new Piperaceae were coming in from many quarters. The eighteen forties saw the full development of the cooperative Esslingen Gesellschaft which sent out botanical travellers in order to obtain rich collections from many different tropical regions in the cheapest possible way. Miquel, now an acknowledged authority in several fields, received many of these collections for identification, especially those from South America.

The position at Rotterdam had remained unsatisfactory also from a social point of view as is clear from Miquel's letter of 1 February 1846 to Schlechtendal. He expresses his great joy to be able to go back to Amsterdam in a greatly improved position and comments on his failure to obtain the Leiden position:

“. . . habe ich nichts hinzu zu fügen als eine für mich glückliche und auch Sie gewiss erfreuende Nachricht, nämlich dass mir, nachdem ich mich bisjetzt in einer sehr ermüdenden socialen Stellung befand, woraus die Regierung mich nicht schien herausziehen zu wollen, jetzt eine ehrenvolle Stellung als Professor ord. der Medizin-Botanik in Amsterdam übertragen ist. Jetzt werde ich alle meine Zeit und alle meine Kräfte der Botanik widmen konnen, und da meine Gesundheit sich bedeutend gebessert hat, erwartet mich eine schone Zukunft.Die Amsterdammer Professur ist mir in sehr verbessertem Zustande angeboten. Meine Freunde hatten mich sehr und lange nach Leiden gewünscht, aber das Schiksal wollte dass sich ein anderer Candidat persönlich schon viel Mühe gab und so die Stelle erhielt, eine Methode die ich infra dignitatem hielt. Meine Adresse bleibt bis Mai in Rotterdam..."

The Leiden position would have carried a higher status and would also have been better paid. The Athenaea had no right to award doctor's degrees and the botanical teaching was very elementary and almost exclusively oriented towards medicine. Miquel's desire for the Leiden chair is therefore understandable. It should be realized, however, that this chair was not combined with the directorate of the Rijksherbarium. The new professor, W. H. de Vriese, found the 
redoubtable Blume in possession of almost all collections of herbarium material. The chair did include though the directorate of the botanic garden. W. H. de Vriese and Blume soon got on each other's nerves and almost never visited each other's institutions.

In Amsterdam Miquel lectured on botany, pharmacology, palaeontology, as well as geology. His courses were taken by ordinary students as well as by outsiders. In 1847 his botanical course was attended by a few young men, non-students, who were interested in a horticultural training as well as by a few manufacturers [sic]. His geological course was very well attended. The report of the trustees for 1847 (quoted by IDENBURG et al., 1927) states that "except six students of the clinical school, two students of the Remonstrantsch Seminarium [theologians], a professor and a private person who had enscribed for the course, there were several other students as well who followed it as auditores. These mixed audiences of students and non-students of a very diverse origin were characteristic of many of the courses at the Athenaeum illustre. In many respects the school was almost a "people's university" with its extension classes. The two other members of the faculty of natural sciences were (in 1850) E. H. von Baumhauer (chemistry) and C. J. Matthes (mathematics). Astronomy, physics, mineralogy, and zoology were not given at all.

The Amsterdam botanic garden dated from 1630. In 1682 it was moved to its present location. As an institution it was more or less independent of the Athenaeum, because it was governed by a group of trustees chosen from the city governors. In Miquel's time the professor of botany was employed by the Athenaeum, but the Hortus botanicus was still independent. This financial independence had been of great advantage in the past because the trustees were often wealthy businessmen or merchants. In the nineteenth century, however, this was no longer so important, and during Miquel's directorate the Athenaeum was allowed to appoint one of its own trustees as a member of the board of the Garden.

\section{Miquel and Mulder}

Although he could leave Rotterdam definitely only in May, Miquel delivered his inaugural adress already on 2 March 1846. The subject was "de regno vegetabili in telluris superficie mutanda efficaci". Apart from the scientific content, interesting because of the broad view taken by Miquel on the changes of the earth's surface so effectively produced by the vegetation, the usual polite social paragraphs at the end provide us with a picture of the friends Miquel found again in Amsterdam. Willem Vrolik had been his professor of medical anatomy at Groningen. With Gerard Vrolik he had been associated for over ten years and he also greeted again several old friends of his early Amsterdam days. The most remarkable paragraph, however, is the one dedicated to a man who did not belong to the staff of the Athenaeum, but whom he wanted to thank publicly for the scientific inspiration he had received from him and for the care and help received from him during his severe illnesses at Rotterdam, Gerrit Jan Mulder: 
"Mulderus certus et immutabilis mihi semper fuit amicus, Muldero Deo favente, bis restitutam valetudinam debeo, a Muldero didici inter varias vitae curas in studiis vivere et ejus in natura investiganda vestigiis insistendi honesta aemulatione me continuo excitatum fuisse, publice glorior".

A few words should be said about the relation between Mulder and Miquel. Since the biography of LABOUChère and the important publication on Mulder by ERNST CoHEN (1948) we have a fairly good picture of the enigmatic and erratic phenomenon called Gerrit Jan Mulder. Even though he had a medical background, like Miquel, Mulder had devoted himself during his Rotterdam days more and more towards chemistry. He had a laboratory of his own in Rotterdam and when he came to Utrecht in 1840 as a professor of chemistry he was the first to start obligatory practical courses for his students. In his later years Mulder, a convinced conservative, became more and more involved in politics and as such one of Thorbecke's most vociferous adversaries. ${ }^{16}$ ) He was an extremely difficult man, short-tempered and unbalanced in his friendships. The road from love to hate was very short with him and it is remarkable that his friendship with Miquel lasted all his life. They had their differences of opinion, but in his later years, when Mulder had become a tragic and isolated figure, Miquel was one of the few people who had still access to him. There are several reports on Miquel's engaging personality, and it seems that this charm worked with Mulder. From Miquel's letter of 30 November 1838 to van Hall we learn that Miquel was instrumental in obtaining for Mulder an honorary doctor's degree at the University of Groningen.

From Cohen's study of Mulder it transpires that the latter's opinions of others, published as well as unpublished, were several times grossly unjust and that Mulder, in his enthusiasm or in his hatred as the case might be, cannot always be considered a reliable witness. This circumstance must certainly be kept in mind when reading Mulder's „Herinneringen omtrent F. A.W. Miquel". On the other hand there is every chance, just because of the relatively peaceful relationship between the two men during the more than thirty-five years of their association, that Mulder's picture is a reasonably fair one. Mulder says of Miquel's Amsterdam period that it was a very happy one because of the general cultural atmosphere, the enlightened attitude of the wealthy board of trustees of the botanical garden, the presence of the academy, and so on: "Miquel would be a thousand times better placed in the capital than on the Meuse. In Amsterdam Miquel soon became president of the Royal Institute of Sciences, Letters and Arts, and later of the Royal Academy of Sciences. He was a highly esteemed trustee of the institute for the blind, and a member of the provincial medical commission as well as of the school commission, and in Amsterdam there was nothing that was close to him of which Miquel was not the generating power, at any rate a first rate 'factor'."

Taxonomy: from South America to the East Indies

Although Miquel had done some work on East Indian plants during 
his Rotterdam days, this had always been a minor part of his work. In Amsterdam, however, he came to a botanic garden richly stocked with new introductions from the Malesian area, mainly sent by Teysmann from the Buitenzorg (Bogor) botanical garden. Just as the Rotterdam garden had stimulated Miquel to undertake some of his most important work (Melocactus, Piperaceae, Cycadaceae), we see him switch over to the study of the flora of the Dutch East Indies because of the living collections in Amsterdam. One of his first objects was to name the undetermined plants in the garden and to publish a catalogue (176). In addition various minor herbarium collections from the East Indies came to the hands of Miquel, in part directly through his association with Hasskarl, Junghuhn, and Teysmann, partly indirectly through Hohenacker and his Esslingen society. Gradually, therefore, Miquel moved towards the study of another tropical flora. We must first deal, however, with some of his other activities.

In the years 1846-1848 Miquel still received much material from Suriname, mainly from Kappler and Kegel (the latter through Schlechtendal) which resulted in some minor articles as well as in the Stirpes surinamenses selectae of 1851 . This book, notwithstanding the word "selectae" in the title, can be considered the real fore-runner of Pulle's Enumeration, certainly if taken in combination with the impressive series of Symbolae published in Linnaea. It virtually rounded off Miquel's studies of the Suriname flora.

It is a pity that Miquel never travelled to any extent. We must find the reason for this mainly in his delicate constitution; hardly a year went by without a longer or shorter period of illness. That these illnesses were no illusion and that Miquel was not a malade imaginaire is borne out not only by Mulder's statements on the Rotterdam period, but certainly also by Miquel's premature death at the age of 59. The cause of his death was to be a liver disease; from the symptoms described in his letters many of his previous illnesses must have been of the same character. Miquel was therefore reluctant to travel. There are many invitations to him in the letters preserved at Utrecht, and he often made plans for trips to the major botanical institutions. One of the few trips that came off was to the two Hookers in 1847, a visit which was one continuous delight to him. The great wealth of material that he found at Kew and at the British Museum almost overwhelmed him. To make the personal acquaintance of Robert Brown and Sir William Jackson Hooker was a revelation; the friendship with Joseph Dalton, dating from the latter's visit to Rotterdam, became one for life.

Miquel never, as far as I know, visited Paris, nor Geneva. He certainly never went to Leipzig or Halle where Kunze and Schlechtendal would have been delighted to receive him, to Munich, where Martius was one of his closest friends by correspondence, or even to Brussels or Berlin. The main trips Miquel made were to the Rhine region to visit the fashionable baths seeking a restoration of his health, to the Ardennes for similar reasons, and also to the Dutch seacoast. It seems never to have occurred to him to make a collecting trip himself and to become 
directly acquainted with the flora of the tropics. His glass-houses and his herbarium sheets were his tropics.

Miquel made collections only in his youth, around Groningen and Rotterdam; later he was satisfied to have that part of the work done by others. It is possible that some of Miquel's work would have been of a higher quality if he had had field experience. On the other hand it must be said that the unevenness in the quality of his taxonomic revisions can more easily be explained by taking into account the varying degree of pressure of other matters. One thing is evident from this sedentary life: it is also possible to become an international figure in botany without travelling and taking part in international meetings. The only meeting of the latter sort that Miquel ever attended was the botanical and horticultural Congress of 1865 in Amsterdam.

The first few years in Amsterdam were characterized by an enthusiastic reconnaissance of the botanic garden. The precious collection of Cycadaceae delighted him and a series of articles on this subject is among Miquel's first contributions from Amsterdam. As a member of the ,Instituut" he was soon editor in chief of the journal published by its first "class" (natural sciences), the Tijdschrift voor de wis- en natuurkundige wetenschappen. It is interesting to look at the composition of the botanical section of the academy in the year 1848. Apart from Miquel we find the venerable Jan Kops from Utrecht, editor of the Flora batava, as „,rustend lid" (over seventy, super-numerary) and as regular members Reinwardt, van Breda, van Hall, W. H. de Vriese, and A. Brants. J. G. S. van Breda ${ }^{17}$ ) has played only a modest rôle in Dutch botany: he published on the orchids collected in the East Indies by Kuhl and van Hasselt. The presence of the agronomist $A$. Brants is interesting not because of his personality, but because it shows one of the characteristics of the old Institute. The "useful" agronomy was included with botany.

During the years 1847 and 1848 Miquel corresponded with Alphonse de Candolle at Geneva on his possible participation in the work on the Prodromus and with Martius on the Flora brasiliensis. In these years he started work on the Piperaceae, Urticaceae and some related families for the Flora brasiliensis. The great collections made by Junghuhn were also put, in part, at his disposal. All this, in combination with his work on the plants from the garden, makes it understandable that Miquel had to refuse de Candolle's request to do the Lauraceae for the Prodromus. The invitation is of interest because it shows de Candolle's broad international outlook (14 Oct. 1867):

"Indépendamment de la valeur intrinsique de vos travaux, je trouverais fort à propos qu'un botaniste Néerlandais vint ajouter son nom à ceux de Suisse, de France, d'Allemagne et d'Angleterre, qui veulent bien m'aider à achever la plus grande entreprise de botanique descriptive des temps modernes. Plus j'avance, plus je sens la nécessité de réunir les forces collectives de plusieurs écrivains répandus dans toute l'Europe car le nombre des espèces connues augmente sans cesse." De Candolle adds frankly that there is no honorarium (there was for the Flora brasiliensis), that he estimates the number of species at around 600, that Miquel would receive all material from Geneva, 
Paris (including Delessert), and Kew and that "le travail devrait se faire en un an". This was too much even for Miquel. He offered to do the Piperaceae, an offer which was accepted but which was accompanied by a request also to do the genus Ficus! Miquel's monograph of Ficus was just appearing during these years in Hooker's Journal of Botany, but was never finished. In the end Miquel did the Casuarinaceae for the Prodromus, Meisner the Lauraceae (published in 1864), and Casimir de Candolle the Piperaceae (published in 1868).

Martius, Endlicher, and Meisner had better luck. The first invited Miquel in 1845 to do the Piperaceae for the Flora brasiliensis. In the end Miquel did the Chloranthaceae, Ebenaceae, Myrsinaceae, Piperaceae, Primulaceae, Symplocaceae, Sapotaceae, and the Urticaceae. This group of families is of considerable size and one must again marvel at Miquel's ability to cope with them. His work for the Flora brasiliensis is on the whole of high quality and certainly worthy of that unsurpassed undertaking.

With respect to the Prodromus and the Flora brasiliensis we again note Miquel's eager participation in the great scientific projects of his time. The Prodromus had been started, in the old tradition, as a one-man undertaking by A.-P. de Candolle. The working power of de Candolle père was certainly not less than that of Miquel or Eichler, but even for him, with a far more limited amount of material than to-day, the task proved too much. Alphonse de Candolle realized that the work could fully succeed only through the international co-operation of all qualified taxonomists. It was his bad luck, however, that the Flora brasiliensis had been started and sucked away some of his potential collaborators. It is natural that we often encounter the same names in the two works, but the Flora brasiliensis had on the whole the upper hand; it also had the longer breath. Until now this Flora still stands alone as a completed work of this type. The Prodromus was not finished; de Candolle later started his Monographiae, which would also never be completed. The enormous achievement of the Flora brasiliensis epitomizes for taxonomy the rebirth of German botany after 1840 . The period 1840-1910 shows science in Germany at its best. Botany in neighbouring countries might be progressing as well but there is no doubt that in this period Germany was leading. It is not the place here to elaborate this theme. The story from Flora brasiliensis to Die natürlichen Pfanzenfamilien must some time be told and put in its right perspective with regard not only to the development of other branches of botany, but also to socio-political and cultural developments. Miquel's contribution to this epic story of science is what interests us here. Already on 7 March 1838 he wrote to Schlechtendal from Rotterdam "Úbrigens erregt es stets mehr meine Bewunderung mit welchem Erfolge die Botanik in Deutschland betrieben wird. Das Centrum Europas ist gewiss auch das Herz der Wissenschaft". Miquel's admiration of German science lasted all his life, but it certainly did not make him blind to developments elsewhere. His associations with botanists in other countries became more numerous and often more friendly and even intimate as years went by, but his 
links with Germany-Martius, Kunze, Schlechtendal-were among the strongest. It was certainly also the open character of German science of that period, its international orientation, which attracted Miquel. This international and open attitude were essential to its success. When during Engler's later days this character was lost, and nationalism prevailed, the downfall of German science was as spectacular as its blossoming had been. Miquel's participation in the work on the Flora brasiliensis, that Germany-based but fully international enterprise, is easily overlooked as less spectacular since it is "only" part of a co-operative enterprise. This work, however, together with that on Suriname, forms, in quantity and in quality, one of his most precious achievements.

\section{The flora of the East and the Rijksherbarium}

The year 1848 , in many respects so important for the development of Europe, also marked a turning point in Miquel's career, though only in its botanical respect. The political events of the year would, three years later, be at the basis of the most serious "affair" in which Miquel would ever be publicly involved, that of the change-over from "Instituut" to "Academie" at the academy of sciences. For the moment, however, the rather conservative Miquel was the surprised spectator of what happened in Germany, Austria and France:

"Die polit[ischen] Verhältnisse, dieser allgemeine Zustand der Dissolution, wird gewiss für alle Wissenschaften schädlich werden. Was soll man von einem Zustande erwarten, wo die Studenten mitregieren, und Zeitungsschreiber am Ruder sitzen. Möchten doch die neulichen Greuel-Szenen von Paris allen vernünftigen Völkern ein warnendes Vorbild sein! Hier ist alles noch ruhig und ungestört [und] können wir noch der Wissenschaft leben [sic]".

It would be a few years before science too would be disturbed in the Netherlands, although only to a minor degree. In the meantime there was another disturbance in which Miquel was involved.

In 1848 Franz Wilhelm Junghuhn (1809-1864), the German surgeon who, during his employment by the government of the Dutch East Indies had become one of the most important scientific travellers in Java and Sumatra, returned to Holland on "European" leave. He brought a sizeable herbarium which he wanted to have studied by the Dutch taxonomists. It would have been natural to deposit his rich collections at the Rijksherbarium, but this was something Junghuhn definitely did not wish. The director, C. L. Blume, had become more and more difficult in his relations with others and more and more reluctant to unpack the collections received from the East for the benefit of taxonomists not connected with the Rijksherbarium. In principle he was of the opinion that all collections made by government employees anywhere in the world, whether officially or even unofficially in their spare time (as was more or less the case with Junghuhn), should come to the Rijksherbarium. This principle was certainly sound as long as it was applied in such a way that qualified 
botanists, at home and abroad, would have free access to the collections. In his later years, however, Blume tended more and more to "reserve" the newly arrived materials for himself. Blume was probably by far the best taxonomist in the Netherlands of his time. He was publishing his sumptuous Rumphia and his Flora Favae, nicely executed folio works with good coloured illustrations. These works were among the best of their type at the time, certainly in scientific respects, though uneven in the artistic quality of their numerous plates. In addition, Blume had published a great many new taxa between 1825 and 1827, while still at Buitenzorg, in the more sketchy Bijdragen. The diagnoses in the Bijdragen, unlike those in his later works, were often too concise for ready recognition. Other taxonomists seem to have had difficulties in obtaining Blume's original material on loan for comparison or revision. This was certainly the case with $W$. H. de Vriese and Miquel. Feelings were, therefore, not of the friendliest. Matters got worse when a Junghuhn plant, named Lycopodium arboreum on a field label, received, by pure chance, premature publicity without Junghuhn's having anything to do with it. Blume scornfully published a refutation of the alleged miracle of the tree-like Lycopodium which was in reality a Conifer (Dacrydium). W. H. de Vriese became involved on Junghuhn's side, and a minor war was on. The details are now irrelevant: they can be learnt from the acid exchange of public letters in the Algemeene Konst- en Letterbode, in Blume's Rumphia, and in other contemporary publications. This personal quarrel between Junghuhn and W. H. de Vriese on the one hand and Blume on the other complicated matters concerning the Rijksherbarium. Blume's inflexible attitude did little to gain him friends and in the years 1848-1850 we find Blume standing alone and fighting a losing battle against those he considered to be his enemies.

Miquel became involved when he changed from the study of the new to that of the old tropics. This change was marked by the opportunity to study parts of Junghuhn's herbarium. On 30 June 1849 Junghuhn wrote to Miquel [translated]:

"In the meantime I have already from the beginning thought of you with respect to my Javanese and Sumatran herbarium and I have entertained the wish that you would take part in working it up." De Vriese and Molkenboer, ${ }^{18}$ ) in Leiden had already arranged it provisionally, and Miquel was invited to come to Leiden and to discuss the work. "The conditions under which I have presented this herbarium, which was assembled by me in former years during my service as a medical officer, to the Government, were: that as long as Mr C. L. Blume is director, the herbarium is not to be buried in the so-called rijksherbarium, but that it may be available for research by Dutch botanists and myself. If these conditions are not accepted, the herbarium remains my property." The government did accept the conditions, thereby publicly repudiating its own servant Blume in the official Rijksherbarium. The herbarium was placed under the care of W. H. de Vriese in his capacities of professor of botany and director of the botanic garden at Leiden. Miquel writes to Schlechtendal (28 Oct. 
1849): "Die Regierung hat darin zugestimmt und also ein aveu gegeben das dem Reichsherbar nicht zur Ehre dient. Und mit Recht."

The ,Akademische Kruidtuin" had already the care of the Splitgerber herbarium. With the addition of the Junghuhn collections Leiden now had two institutional herbaria. When the Rijksherbarium had been transferred from Brussels to Leiden in 1830, it had been combined with the old academic collections.

The next step taken to obtain access to the collections from the East Indies was by Miquel and de Vriese separately. Both addressed themselves formally to the minister of the interior, Thorbecke, with complaints and a request for a new instruction for the director of the Rijksherbarium. It is not necessary to spell out the details. Miquel's letter is known to me only from annotations by de Vriese in the archives of the Rijksherbarium (file for 1850). One phrase from the Vriese's letter may suffice to show the unnecessarily acrimonious character of the quarrel (translated): "[The Rijksherbarium] was never anything else but the focus of the morbid ambition of a single man ...". Miquel's argument had mainly been that he had received complaints from foreign botanists. It is true that in the letters addressed to him, now at Utrecht, we find indeed several very critical remarks about Blume. The Leipzig botanist Gustav Kunze, for instance, wrote to Miquel on 18 Jan. 1849 "Ich habe bei mehreren Gelegenheiten darauf hingedeutet ... dass über seine früher beschriebenen Pflanzen kein Aufschluss zu erhalten ist'. After first having tried to convince Blume in private, by letter, to change his policy, Thorbecke came to the conclusion that the only solution would be to issue publicly a new instruction. The ukase came off on 11 November 1850 and was published in the ,Staatscourant". Reprints were sent to various botanical journals. Miquel comments to Schlechtendal: "Jetzt hat endlich die Regierung einen wichtigen Schritt gethan und eine sehr liberale Instruktion für ihn [i.e. Blume] ausgefertigt, die Sie wahrscheinlich schon kennen werden da der Minister Massregeln getroffen hat dass auch apud exteros diese eigentlich strafende Instruktion bekannt werde",

The instruction made a great difference and, strictly speaking, went even a little too far into the other direction. All material of any group, but not more than that of one family at the same time, had to be given on loan on request to botanists of acknowledged standing. The director was allowed to retain "a few families" for his own studies in his spare time [sic!]; he was no longer allowed to make use in his publications of manuscript annotations by others. Duplicates had to be distributed on a liberal scale.

Although the instruction was carried out by Blume in a very incomplete way, as would become clear in 1861 when Miquel became director, the immediate result was that some of the undetermined collections became available for study by others.

The relations between Miquel and Blume remained strained for the time being. Miquel reviewed the latest instalments of Blume's Rumphia and Museum Botanicum for the Algemeene Konst- en Letterbode and revealed, 
first very quietly, later in a more outspoken way, Blume's practice of ante-dating his publications.

Miquel's interest in the flora of the Dutch East Indies became now more and more pronounced. Plans matured to undertake an enumeration of everything known on that flora, completed with new information from the collections at the Rijksherbarium, the Horsfield collections at the Linnean Society, Reinwardt's private herbarium, and some other collections.

In the course of $1854 \mathrm{Miquel}$ sought the help of the government for his plan to write a Flora indiae batavae. Junghuhn enthusiastically supported the project with the government and towards the end of the year Miquel had received sufficient safeguards to make a beginning. On 9 November he wrote to Schlechtendal: "Ich meditiere nämlich einen grossen Plan, auf Veranlassung und sub aegidie unserer Regierung eine Synopsis, d.h. eine nicht weitläufige, aber eine so gut möglich vollständige, das Bekannte zusammenfassende Flora Indiae batavae zu bearbeiten". On 12 February 1855 he gave further details and stated "Die Regierung interessiert sich sehr für das Unternehmen, unterstützt und befördert es". From then on publication took place rapidly. The first part appeared on 2 August 1855. The presentation is modest and with a minimum of illustrations, the latter as always by his friend Ver Huell. The circa 3700 pages and 41 plates appeared in slightly over four years: the last part was published on 29 December 1859 when Miquel was already at Utrecht. In sheer size the Flora (167) is matched among Miquel's publications only by his later Annales. The book constitutes the first comprehensive flora of the Malesian area and was evidently inspired by the Flora brasiliensis, though published in the style of de Candolle's Prodromus. The descriptions are in Latin, the notes (mainly on use, pharmaceutical properties, and distribution) in Dutch. The motto for the book is the same as that used for Miquel's first major success, the Systema Piperacearum: Augustinus' "Perinde quisque hoc legat, ubi pariter certus est, pergat mecum; ubi haesitat, quaerat mecum; ubi meum errorem agnoscit, revocet me; ubi suum, redeat ad me". "Whoever may read this, where is he of like mind with me, let him continue with me; where is he uncertain let him inquire with me; where he recognizes my error, let him restore me; where his own, let him return to me" [translation by H. W. Rickett].

In his introduction to the first volume Miquel states some of his basic principles (pp. viii, ix). "I do not aim at the applause of those who seek the good of science in the multiplication of species and genera. . . . Not he who adds most new names to the lists of plants, but he who tries to clear them from all those products of thoughtlessness and self-love, promotes true science. The principles of a correct evaluation of the differentiating characteristics of species must be found in the realm of organography, anatomy, and physiology, in order that the plant does not present itself to the mind of the taxonomist as an unchanging being such as the dried herbarium specimen. He must trace the laws of plant distribution in order to learn to distinguish the effect of all outside influences which modify the shape of the species in combination 
with the gradual changes in the development of the organs. Only in this way can he obtain a correct delimitation of the species." It cannot be denied that, though in the language of his time, the principles are very advanced. Herbarium specimens alone are not to be trusted, characteristics derived from other branches of botany have to be taken into account. Undue splitting is harmful and to nobody's advantage. The variability of species is taken seriously.

In evaluating this work it must be kept in mind that it was intended as a compilation of knowledge accumulated during the preceding decades, incorporating all data on unidentified material on which Miquel could lay hands on. It was also no true "Flora", because of the absence of keys. Therefore it cannot be compared with contemporaneous critical Floras, such as Wight \& Arnott's Prodromus, Hooker \& Thomson's Flora Indica, or Bentham's Flora Hongkongensis. The marvellous diligence and completeness with which this project was executed prohibited of course such critical revisions, and the great hurry in which it was compiled entailed a not inconsiderable number of botanical inaccuracies. That it could by no means represent a fair account of the flora of the area covered must have been obvious to Miquel himself, as some large new collections from the island of Sumatra, by Teysmann and Diepenhorst, induced him to write a first Supplement dedicated to the Sumatran flora (185). Such compilations are, however, very useful tools, and Joseph Dalton Hooker, himself at work on the Indian Flora, wrote on 13 January 1861 to him: "I am very glad that you have finished your valuable flora, a work of extreme use and importance to all botanists". The restricted aim and value must have been well understood by Miquel as he pursued the study of the Netherlands Indian flora by revisions of groups, partly by himself, partly by other specialists, in his Annales (207). He was engaged with this until his death as can be seen from his partly posthumous Illustrations de la flore de l'Archipel Indien (292).

Now that we have an approximate idea of the size of the Malesian flora, we are not surprised that Miquel could not produce a basic, critical work, as collections were at his time totally inadequate. Possibly he also underestimated the colossal wealth of the tropical floras, having had himself no opportunity to visit the tropics. But we should still be grateful for his valiant attempt to master this colossal task single-handed. Also, for a botanist who had no personal acquaintance with the tropical flora, his general introduction and his plantgeographical insight in the delimitation of Malesia and its botanical provinces, testify his command of the matter.

\section{Miquel and the "Institute"}

The Netherlands academy of sciences, literature and arts, called ,Het Koninklijk Nederlandsche Instituut van Wetenschappen, Letterkunde en Schoone kunsten", was by origin and character a product of the Napoleonic era and was set up in almost the same way as its French counterpart the Institut de France. In the year $1850 \mathrm{Miquel}$ had 
become president of this venerable institution. In 1851 the liberal minister of the interior, Thorbecke, decided that a reorganization was in order. True to his belief that sciences and arts are no affairs of state and flourish best in complete independence, Thorbecke had for years been opposed to this state institution. Although himself a member, he was of the opinion that it protected, with tax money, arts and artists, science and scientists that could better thrive in independence. On 26 October the Institute was abolished and replaced by a similar institution consisting only of the former class of natural sciences: the Koninklijke Akademie van Wetenschappen. Miquel, as president, was officially charged to bring the change into effect. In view of the storm of protests in the Dutch world of science, Miquel's task proved to be one of the most difficult of his life. A great number of documents and letters connected with what soon became a real "affair" was kept by the general secretary of the old Institute, W. Vrolik. This file, which is now in the archives of the Academy of Sciences, gives us an insight into Miquel's character which is almost unique, even though the factual information is sketchy. No records of oral negotiations and behind-the-screens conversations exist. The affair is of purely historical importance, but still of sufficient interest to be briefly recalled here. A detailed study giving also information on the events preceding the change-over is given by Huizinga (1922).

The old Institute had often been severely criticized as being oldfashioned and out of touch with practical life. There were four classes: (1) natural sciences and mathematics, (2) Dutch literature and history, (3) eastern and classical studies, philosophy, general history, and archeology, (4) fine arts. The statutes reflected the basic ideals of the Enlightenment as discussed above in connection with Miquel's time as a student at Groningen university. The ideal was eighteenth century French with Napoleonic overtones: the institute as a showplace of the splendour of sciences and arts in a strictly centralized, benevolent, semi-authoritarian state. A show-place because it demonstrated optimistically that by industry, emulation, and dedication under a patriarchal government, this world would become the best of all possible worlds. Industry, usefulness, the subservient nature of science: all are just as characteristic for the Institute in the early half of the century as they were for our Universities. Huizinga writes that after 1840 voices became louder and louder in pointing out that the Institute had really never fulfilled its task: the perfection of arts and sciences, the integration of science with society had never taken place. The purely utilitarian English liberalism of Thorbecke had no use for such a subfossil from the times of the Enlightenment. However, by disregarding the essential rôle of science in society, and by limiting the new academy to the natural sciences only, Thorbecke overshot his mark. The abolishment of the old Institute with its various branches and the foundation of an academy of natural sciences was only a preliminary phase in the birth of a new view of science, a view that we have seen growing with Miquel in the fifteen years before these events. In 1855 the Academy would be completed again by the creation of a 
second department for the philosophical, philological, literary and historical sciences. In a new form, and without the optimistic, slightly overdrawn ideals of a vanquished past it would represent independent and pure science in a liberalized society. The academy was not to direct science, but to represent it with the government and with society. Huizinga says that after a French beginning as the Institute, the Academy was first too rigorously cut short in the English utilitarian spirit of the time, to be finally reorganized in accordance with the German ideal of the aims and value of science. "Scientific life in Germany had not in vain been developed on an unprecedented scale, unequalled by others. The purely scientific division of the subjects in a mathematical-physical [natural sciences] and a philological-historical section had been the basis already in 1812 of the reorganization of the Prussian academy." While our minds turn to Heine again for a moment, it is good to realize that Miquel was among the first in the Netherlands to acknowledge and to follow the examples of German science in the greatest period of its history. In his handling of the transformation of the academy he consciously worked with this object of an independent science in mind.

After the publication of Thorbecke's decree of 26 October 1851 Miquel called a special general assembly of the Institute to be held on 15 December 1851. In his address (152) he pointed out that a valiant battle had been lost. The economy drive begun after the secession of Belgium had had its effects on universities and academy alike, and science had suffered. The proposals for a reorganization tentatively put forward by the Institute itself had never been developed because of lack of response from the government.

A committee was appointed to transfer the possessions of the Institute to the government on 31 December. This committee met on that day, and drew up an inventory. In the absence of a representative of the government to accept the library, the funds and the miscellaneous possessions, it closed the procès-verbal and decided to hand over the keys to the janitor of the academy building. The meeting must have had something of the character of a comic opera, because just when the committee was breaking up Miquel appeared in the meeting: „waarop zich des namiddags ten half drie ure bij de Commissie aanmeldde de Heer Miquel, die haar een depêche aanbood door den elektro-magnetischen telegraaf overgebracht, waarbij hij in naam van den Minister wordt gemachtigd, ten behoeve der Koninklijke Akademie van Wetenschappen over te nemen de bezittingen van het Koninklijk Nederlandsche Instituut'. ${ }^{19}$ )

Miquel carried a telegram empowering him to act on behalf of the new Academy. The committee was not at all impressed by this modern way of delegating power: after all what was a telegram? They considered themselves bound to refuse (,verpligt te zijn tot weigering van gehoorzaamheid aan eene lastgeving op deze wijze overgebracht ...") and made a new procès-verbal. Two days later, when the written authorization was in hand Miquel was again received by the Committee and the transfer could take place. 
What had happened in the meantime was that a powerful opposition had arisen not only to the abolishment of the Institute but also towards accepting the appointments to the new Academy. Thorbecke, in his decree of 26 October 1851 had appointed all members (ordinary, extraordinary, and retired) of the former first class (natural sciences) as members of the new academy. Among them there was now a movement, under the strong guidance of G. J. Mulder and W. Vrolik, not to accept new membership. This movement did not carry the approval of the entire group, but it was strong enough to prevent a quick change-over. Miquel, who had himself been strongly opposed to the abolishment of the Institute, was officially charged with the operation of the change-over in his quality as president of the old Institute and of the new Academy. He was therefore hors-combat, and did not participate in the further deliberations of the opposition. From the Vrolik file it is clear that most members realized this and respected his standing aside. A first meeting of the Academy called by Miquel and held on 24 January fell flat because only a very few members showed up. On that same day 15 members (11 of the 25 ordinary, 2 of the 21 extraordinary, 2 of the retired members) sent a letter to the King declining the appointment. In the meantime, Miquel, who had been kept informed inofficially, had not been quiet. In a confidential letter of 18 January 1852 to W. Vrolik, the Utrecht member G. van Rees explains Miquel's attitude and plans. Miquel was of the opinion that since the old first class, at its last meeting, had not decided as a group to refuse appointment, the only way open was first to accept and then to improve. In view of the opposition, however, he was convinced that the new Academy would fail and he took steps to let Thorbecke change the instruction for the academy, and to let the king speak a ,verzoenend woord" (reconciling word). With the powerful opposition of the group of fifteen he had some backing for his diplomatic negotiations. How he did it is not entirely clear, but the result was that the king (not exactly a friend of Thorbecke) wrote indeed a personal letter, dated 30 January 1852 , to each of the members who had declined appointment. In a modern democracy this letter would be frowned upon, but king Willem III of the Netherlands was not quite accustomed yet to the idea that his rôle was symbolic only and that his ministers were the ones who governed. On the other hand Thorbecke may well have known of this move and have welcomed it because it saved the faces of both parties. The king requested acceptance as a personal favour to him. He wanted the collaboration of the scientists ,in de hoop dat daardoor tenminste gedeeltelijk zou worden vergoed het gemis van het Koninklijk Nederlandsch Instituut, en dat deze nieuwe instelling [i.e. de Academie]den grondslag zal mogen uitmaken voor eene toekomstige, welke ook andere dan de natuurkundige wetenschappen in zich opneme". The king therefore wanted acceptance in order to make good the loss and as a basis for a possible future academy which would also comprise branches of science other than the natural sciences. The letter was a complete success, and the opposition accepted appointment. 
In retrospect there is every reason to affirm the conclusion of Matthes in 1872 that it was "Miquel's influence, his manly and calm action, his cautious and intelligent policy", which assured the future of the Academy. Huizinga too concludes that without Miquel there would have been no Academy after 1851. The re-organization which was undoubtedly necessary now came about in a mere four years. If there had been a definite break, this period might have been much longer. ${ }^{20}$ )

\section{Palaeobotany and Uilkens}

In the beginning of his Amsterdam period Miquel became interested in palaeobotany. He lectured on this subject at the Athenaeum and a further intimation of this interest is found in a letter to Schlechtendal of 24 February 1849 in which he writes "bei der Haarlemmer Gesellschaft der Wissenschaften ist auch auf eine Frage [a prize-question] über die fossilen Coniferen eine classische Arbeit eingegangen". The name of the author was still unknown, but it was soon revealed that the answer was from the hand of Heinrich Robert Goeppert (18001884) at that time already one of Germany's most outstanding botanists. Though primarily a palaeobotanist and morphologist Goeppert was an all-round botanist who successfully built up his botanical institute and herbarium at Breslau to be a model of its kind. The "Preisschrift" was his Monographie der fossilen Coniferen of 1850. Goeppert visited Miquel in Amsterdam in 1850 and stayed with him at his house. The two men had been in contact as early as in 1837 on a question regarding the anatomy of the roots of living Cycads. In the meantime Goeppert had evolved towards palaeobotany and now we find Miquel's interest stimulated again by Goeppert's work, which involved Miquel's beloved Cycads. From then on the contact remained close and resulted in a regularly exchange of fossil material.

In 1852 the Dutch government decided to set up a Committee to provide a geological description and map of the Netherlands. J. G. S. van Breda was appointed chairman, W. C. H. Staring ${ }^{21}$ ) was secretary, and Miquel "member". The committee started work immediately and produced a first report in 1853. This report contains Miquel's article on the fossil plants from the Limburg chalk (159) in which he described numerous new fossil taxa. The Committee continued its work until 1855 when it was dissolved because of fundamental scientific disagreement between its members.

Miquel's interest had been awakened, and palaeobotany, geology, and even mineralogy, remained among the subjects that he taught at Amsterdam and Utrecht. In $1855 \mathrm{Miquel}$ published one of the most interesting books of his career: his treatment of geology for the new "Uilkens" (168). In the discussion of Miquel's early years at Groningen University we have already mentioned this book as an illustration of the spiritual climate of the Netherlands in the first part of the century. The new Uilkens, however, was no longer the same as the original one. The times of the country-clergymen who could become professor 
of rural economy at the universities were over. No longer was it possible for one man to deal with the full scope of the natural sciences: a team of scientists was taking Uilkens' place. H. C. van Hall dealt with the botany volume, published in 1852. Although entirely rewritten, it still breathes the old spirit of an almost exclusively descriptive botany with frequent exclamations heralding the beauty and harmony of creation, and the infinite wisdom of its creator. No controversial subjects are touched upon; mutual relationships are purely formal, and the tendency of modern botanists to start thinking of evolution is completely ignored.

Miquel's volume "containing considerations of the minerals and the history of the earth" is written in a different key.

When dealing with a subject like this, and especially with the sequence of fossil plants and animals in time, it was impossible to ignore the awakening of evolutionary thinking. It cannot be said that Miquel, conservative in character and scientific views, had much sympathy for "the so-called theory of evolution". He was not blind, however, to the implications of the latest geological and palaeontological findings. He firmly maintained his orthodox christian point of view that the changes and successive steps in the evolution of the earth as well as of its living beings, are all acts of creation. Parenthetically he remarks that the hours of the day of creation are "for His eye the countless billions of years". The book has as its motto a long quotation from Cuvier's Discours sur la révolution de la surface du globe in which he says " $N$ 'y aurait-il pas aussi quelque gloire pour l'homme à savoir franchir les limites du temps, et à retrouver, au moyen de quelques observations, l'histoire de ce monde et une succession d'événemens qui ont précédé la naissance du genre humain?" A faint echo of the old theory of cataclysms can still be heard in Miquel's statement: "to which measure must rise our admiration of God's greatness, when we convince ourselves that numerous [he even says literally "many numerous"] Creations of plants and animals have existed on earth and followed each other steadily". Further on, however, he makes the fundamental remark, derived from Charles Lyell, that "when we compare all those different creations [decapitalized] with each other and also with those of the present time [sic], we find in all the same laws of formation, in all together one unity, one basis, one original thought". He sees a regular development in which more complicated plants and animals replace simpler ones. There is a continuous change, succession, and development in accordance with constant laws. These constant laws, he says, again parenthetically, do not exclude man. Furthermore: "creation extends therefore from the beginning onward until our times". This is all very clear, although still expressed in a conventional way. "For the Supreme Being there is no distance in ages". However, Miquel stresses that after the creation of man, "we see at least no new forms arise, though some disappear". He does not want to discuss the explanation given by the "so-called materialistic school" which makes the entire creation into one big automaton, but he wants to deal with the so-called development 
hypothesis or theory of evolution, which comes forward again and again, and which is "a hypothesis to explain the succession of various creations in an apparently simple and natural manner". Lamarck was an exponent of this modern theory. The nature-philosophers in Germany, under Oken, went even further. In order to show that such theories are of no avail, Miquel extensively quotes Hugh Miller's Footprints of the Creator. Miller's successful but superficial work is too well known to be quoted here. Miquel strangely enough did not discern its fundamental weakness and gave perhaps too much attention to Miller's often justified criticism of Oken's speculations, thereby underestimating the important observations made by Darwin on the Galapagos Islands. We find Miquel's scientific judgment limited here by extraneous factors. The famous "superposition not parental relation" is too attractive to him and so is Miller's "successful combination of Christian doctrines with pure scientific truths" (Louis Agassiz, 1850). Miquel is [still] convinced that there is a constant process of creation by an almighty Creator. This process may or may not continue beyond the creation of man. The scientist's duty is to learn in what order this continuous ascending creation (,,voortgezette opklimmende schepping") took place. Darwin's early work, known to Miquel as well as to Miller, did not influence his conviction, but it must be said that his book was published four years before the publication of The origin of species. Miquel was fully convinced that there was a succession, but an "evolution" by means of natural processes was for the time being foreign to his mind.

\section{Miquel and Cinchona}

The "acclimatization", to use a term of the period, of the quinine producing Cinchonas in tropical regions outside South America was one of the great problems of applied botany in the nineteenth century. Quinine was perhaps the most important medicine of the century, used against a variety of diseases of known as well as of unknown origin. "No medicine without quinine", the often quoted saying of the time, was hardly an overstatement. The history of the introduction of quinine into Java has been written and rewritten: an enormous professional literature exists (see e.g. v. Gorkom, 1884, 1896; and Moens, 1882) in addition to a great many journalistic and polemical articles in the popular and semipopular press. It was almost impossible for a Dutch botanist who was more or less informed on the tropical flora not to be involved in the Cinchona-question. When, in the beginning of the century, reports of the depletion of the natural Cinchona supplies in South America became frequent, the governments of France, England, and the Netherlands became gradually interested in trying to grow the South American species in their African and Asiatic colonies. The Dutch attempt met with the most spectacular success: by 1930 the Dutch East Indies supplied 95\% of the world's Cinchona bark. This success was due to a number of factors, intentional as well as unintentional, which are summarized by KER- 
возсн (1948). Miquel's rôle in this process was modest, although his interest in and occupation with the Cinchona culture lasted from 1846 until his death.

The first Dutch botanists who tried to convince their government of the need to introduce Cinchona in the East Indies were C. L. Blume, P. W. Korthals, and G. G. Reinwardt, all from Leiden, in 1829 and 1830. Nothing happened and several others tried to awaken the lethargy of the colonial office and the highest quarters in Batavia: G. J. Mulder in 1838, G. Vrolik in 1839, and Miquel in 1846.

Miquel seems to have sent a plant named Cinchona alba from the Amsterdam garden to Batavia as early as 1847. VAN GoRKOM relates (1884) that he saw this plant in 1856 in Weltevreden and that it was one of the "false" Cinchona's, Cascarilla muzonensis [Ladenbergia muzonensis]. A further consignment was made by Miquel on 20 May 1851 when a number of young Cinchona plants were sent to the East Indies, again from the Amsterdam garden. On 24 August 1851 the Governor-general, Duymaer van Twist, wrote to Miquel to acknowledge the receipt. Only one plant had survived, and Teysmann, the director of the Buitenzorg botanic garden, had it under his care. Duymaer van Twist asked Miquel to send more material from Amsterdam, stating that he would receive, in exchange, anything he wanted from the Buitenzorg garden. According to Miquel's own account of the history of the introduction (no. 262) the plant of 1847 was a "bad species", but the later consignment from Amsterdam was one of true Calisaya's which, however, did not survive. Teysmann's efforts had been in vain. These "Calisaya's" belonged to Cinchona calisaya Weddell, a species sometimes considered to be only a variety or a forma of C. officinalis $L$. The next consignment of Calisaya's was made by W. H. de Vriese from the Leiden garden and met with more success, because at least one plant survived. The plants had been grown from seed received from the British-French Cinchonatraveller Weddell. These first introductions, however, were of no practical importance: cultivation on any scale could start only when the seeds and plants collected by Hasskarl on his famous mission to South America of 1852-1854 were received. From then onward numerous introductions of seeds, seedlings, and cuttings followed and Miquel was often involved in their identification. When Junghuhn was put in charge of the Cinchona plantations in Java he succeeded in growing many thousands of trees in a relatively short time. It soon became clear, however, that the great majority of these trees yielded a bark with a very low quinine content. Junghuhn continued the propagation of the low-yielding but fast-growing trees, but others, at home and in the Indies, pressed for a sharper selection towards higher quinine content of the barks. In this connection the taxonomist's ability to distinguish the taxa with different yields became of great importance. Miquel later described several new species of Cinchona from Java introductions in his De Cinchonae speciebus quibusdam of 1869 (285). In the preceding years, however, he had repeatedly been asked to give advice. Mulder relates that on one occasion, when Miquel 
and he himself objected to the great numbers of trees belonging to $C$. pahudiana Howard (correctly $C$. carabayensis Wedd.), Junghuhn disputed their assertion of the low quinine content. To settle the question the government ordered Junghuhn to send a whole tree to Utrecht for taxonomic and chemical inspection. Junghuhn reluctantly did so, using a black coffin as the means of transportation. This sardonic humour tickled Miquel greatly. They confirmed their findings, but it took another few years, until van Gorkom took over the direction from Junghuhn, before the policy changed.

It was by pure chance that Miquel played a decisive role in the ultimate success of the Cinchona experiment. In 1865 the English traveller Charles Ledger received a quantity of seeds collected by an Indian in Bolivia. These seeds were sent to England, where his brother George Ledger tried to sell them to the English government. In the absence, however, of the experts J. D. Hooker (through illness) and C. R. Markham (in India) part of the lot was offered for sale to the Dutch government on 17 October 1865. The government sought Miquel's advice on whether or not to accept the offer. Miquel, always eager to introduce new blood, advised positively. The seeds were bought for $\mathrm{fl}$. 100.- [sic]. Although this was not known until a few years after Miquel's death, this introduction proved to be a fantastic success. This Cinchona ledgeriana Moens, as it was later called, was found to produce in 1879 a bark with $13.5 \%$ quinine as opposed to the $1.0-1.5 \%$ of the other "species". Cinchona ledgeriana became the sole basis of the Cinchona cultivation in the Dutch East Indies and assured the complete success of the undertaking.

Miquel's taxonomic work on Cinchona, however, does not stand undisputed. STANDLEx, in his recent treatment of the genus for the Flora of Peru (1936) reduces several of Miquel's species to synonymy, and seriously questions the standing of most of the others. Miquel's species were mainly based on plants cultivated at Java from seed brought by Hasskarl. Towards the end of his career Miquel received seedlings of the Ledger plants and labelled them $C$. calisaya Weddell in the Utrecht herbarium. The differentiating characteristics are derived from adult and flowering specimens. The rank attributed to these taxa was of relative unimportance for the practice of Cinchonacultivation: it was the possibility of distinguishing them at all that counted. In Cinchona Miquel had a lucky hand, certainly as far as the industry was concerned. Miquel received the order of the Dutch lion for his efforts on behalf of the Cinchona cultivation. His own comment was " ... dass wir die China-Kultur auf Java eingeführt haben. Die Sache gelingt vollkommen! Die Bergregion ist sehr tauglich dazu. Ich vermuthe das es deshalb ist, dass der König mich zum Ritter des Löwen-ordens promoviert hat!'22)

UTRECHT AND LEIDEN, A NEW GOMBINATION: 1859-1871

Miquel's old adversary, C. A. Bergsma, professor of botany at Utrecht, died on 22 June 1859 at the age of $61 .{ }^{23}$ ) Miquel was the 
obvious candidate to succeed him and on 7 August 1859 the appointment was announced by the government. ${ }^{24}$ ) Mulder did not quite understand why Miquel wanted to come to Utrecht at all: there could be no financial reasons, he says, "because at Utrecht-a resort that used to be called so wholesome-one still believes that a professor can live on air". The main reasons why Miquel came must have been two. There was first undoubtedly the "wholesome air", a circumstance of great importance for him because of his frequent illnesses. Utrecht had indeed a reputation as a healthy place to live, mainly because of the absence of malaria. The second reason may have been that the University of Utrecht, whose scientific standing had steadily increased during the century, was something different from an Athenaeum. Miquel would be able to have pupils that could obtain a doctor's degree in botany. The number of students in the natural sciences on 15 November 1859 was only 10 (in Amsterdam: 2), but that might change, and a small number had its charms anyhow. In the year of his death this number was 57 . Utrecht was not a big university-455 students in 1859 and a faculty of natural sciences of only 7 professors, but always more sizeable than Amsterdam, which had only 107 students that same year, and a faculty of only three professors. ${ }^{25}$ ) The teaching in the natural sciences at Amsterdam was almost exclusively directed towards the medical students, at Utrecht the natural sciences were also taught per se. The Dutch universities were all small: Leiden had 537 and Groningen 183 students in 1859.

Before coming to Utrecht, however, Miquel made some conditions, through the intermediary of Mulder: a free house in the botanic garden (now the Miquel-huis), a gas lantern above his door, and the transfer, for payment, of his private herbarium to the University. The house, however, was not free and the lantern was not placed until much later. The transfer of the herbarium took place only in 1862.

On 28 September 1859 Miquel delivered his inaugural address at Utrecht. ${ }^{26}$ ) This time it was no longer in Latin but in Dutch. The courses at Utrecht were now also given in Dutch. The address dealt with "the present position of botany with respect to other sciences". The year 1859 was the year of the publication of Darwin's Origin of species. From the above account of Miquel's contribution to "Uilkens", we know that he was not very receptive towards what he called a materialistic explanation of creation. The fixity of species was still indisputable for him when he wrote his account of 1855 . In the meantime, however, a remarkable change must have occurred in Miquel, very probably mainly through his better acquaintance with the publications of Hofmeister. The latest microscopical research had now put the omne vivum ex ovo beyond doubt: "the philosophy of nature now recognizes that sexual reproduction among plants is a direct continuation of the individual of which the germ is a part; this reproduction is therefore a continued division, the species must be seen as a series of identical parts, as one individual of a higher rank, designed for a certain space of time in the history of the earth". This statement embodies Miquel's evolution towards a biological 
species-concept. He continues along revolutionary lines: "what was the origin of the succeeding creations? ... Is it not more correct to find in the species itself the cause of its end? Has not every individual a limited duration of life and would not the higher individual, the species, be subject to a similar law? However, the way in which new organisms arose remains a question to which science has not yet presented an answer ... There are among present-day scientists some who think that this question is beyond the reach of science. This opinion is probably premature, especially when one realizes that of late research on sexual reproduction has revealed a number of entirely unexpected phenomena such as, for instance, the change of a species into a number of different series which reproduce independently. If the natural sciences are to explain the succession of creations, it would seem that the basis for this explanation would have to be sexual reproduction."

The change in Miquel is remarkable, but not unexpected. Living in the nineteenth century and being fully aware of the value of the findings of pure science, he had only waited to be convinced. The fixity of species is no longer mentioned, on the contrary, the possible change into "different series" is definitely accepted. Here, in this inaugural address, we find one of the finest aspects of Miquel as a scientist.

\section{Miquel's herbarium}

Miquel's private herbarium is the basis of the Utrecht University herbarium. It contained the collections obtained by him in many different ways since his student days in Groningen. Through his work for international co-operative enterprises, and for owners of herbaria like Delessert, Franqueville, Lehmann and W. J. Hooker, who were eager to have certain groups named by specialists, Miquel received many duplicates from important collections. In addition he received many collections from Suriname and the Dutch East Indies on a personal basis. This material constituted Miquel's herbarium in 1859. His herbarium contained the types of many of his new taxa, although quite a few types are among the collections which he received on loan from others, and which are now at Paris, London, Kew, and Geneva. The Rotterdam clinical school and the Amsterdam botanical garden had no herbaria of its own and Miquel had simply followed the custom of his period to build up a private herbarium. It was this herbarium which was transferred to the Utrecht University in the first instance in 1859, but definitely in 1862 after Miquel's appointment as director of the Rijksherbarium. In this later position Miquel was not allowed to have a private collection, a circumstance which helped greatly to speed up the transfer at Utrecht. The material received after 1862 by Miquel and added to the Utrecht herbarium was solely that received privately, such as the specimens of Cinchona from the East Indies, as well as a very limited number of duplicates from the Rijksherbarium. This number was so limited because the 
exchange Leiden-Utrecht took place on a scrupulously observed basis of numerical equality, and Utrecht had little to offer. Miquel had long before used his duplicates for exchange. The story, therefore of Miquel travelling to and from Leiden with a stream of plants going only in one direction, which does not lack charm, definitely lacks truth. Miquel's strict sense of propriety was rarely more evident than in the years when he combined his Utrecht position with that of the directorship at Leiden.

\section{The Rijksherbarium and the flora of Japan}

Both Blume and de Vriese died in the beginning of 1862, and thus both the directorate of the Rijksherbarium and the professorship of botany at Leiden became vacant. The formidable Thorbecke, who had so effectively supported Miquel in 1850 in "opening" the Rijksherbarium, who had found Miquel at first against him in the affair of the Academy of Sciences, was still in power. He first turned to Miquel to fill the vacancies because the latter now ranked indisputably first among his fellow-botanists in the Netherlands. It is interesting and revealing to let Miquel tell himself - again in a letter to Schlechtendal -the story of his dual appointment, and the reasons for his refusal to live at Leiden (18 May 1862):

"Die Regierung war mit der Sache sehr verlegen. Das Reichsherbarium hatte der Regierung wenig Freude gemacht, viel Geld gekostet; so lange Blume lebte konnte und wollte man nicht eingreifen. De Vriese's Tod erhöhte die Schwierigkeit, denn man fand Bedenken den jungen Dr Suringar, der nur für de Vr[iese's] Abwesenheit als Prof. extraord. angestellt war, zu dessen Nachfolger in der bot. Professur zu proclamieren. Es wurden nun beide Stellen mir vereinigt angeboten und der Minister wollte mich durchaus nicht loslassen; er wies mich auf meine Verpflichtung gegenüber die Wissenschaft u.s.w. $\mathrm{Da}$ ich aber mich hier in Utrecht ganz wohl fühle und in dieser freundlichen und gesunden Stadt mit meiner Familie viele Elemente des Lebensglücks finde, hier mit meinen Collegen in dem angenehmsten Verhältniss stehe, hatte ich wenig Lust nach dem fieberreichen Leiden, dass ausserdem eine sehr stille Stadt ist, mich zu begeben. Das Endresultat ist nun, dass man an Suringar den Lehrstuhl der Botanik übertragen hat und dass ich zum Director des Reichs Herbarium ernannt bin, zugleich aber hier an der Universität bleibe. Die Eisenbahnverbindung macht diesen Zustand möglich, wobei gewiss meine Thätigkeit sehr in Anspruch genommen werden wird. Ich hoffe nun das Reichsherbarium so viel möglich dem In- und Auslande offen zu stellen damit die Massen von unbearbeitetem Material der Wissenschaft zum Nützen werden können".

The change-over did not take place without difficulties. Miquel had to dismiss the curator $H$. van $H a l l$, the son of his old teacher $H$. C. van Hall, thus reducing the staff of the Rijksherbarium (in addition to himself) from three to two. Angry protests followed from certain Leiden quarters, which found expression in the debates in the house of 
representives (Tweede kamer) on 25 November 1862. The member for Leiden was not at all pleased and greatly objected to the new policy. The debate in the House revealed some interesting aspects of the state in which the Rijksherbarium had been found after Blume's death. Thorbecke faithfully stood by his choice of Miquel.27) Not published was the fact revealed by the archives of the Leiden Rijksherbarium that Thorbecke had wanted Miquel to dismiss two of the three employees of the Rijksherbarium. The dismissal of only one was again a typical Miquel compromise.

Shortly after his appointment Miquel fell ill for a long time and had to go on vacation to Bad Soden in Germany for a complete recovery. In the autumn, however, work could be started. The untouched collections of many travellers, found stowed away in rooms at the Rijksherbarium that had not been open to the public, were brought to light. Miquel wrote to many of his colleagues in Europe and in the United States to invite collaboration in naming the collections and describing the new species. He offered duplicates in return for their services and he furthermore started an extensive exchange program. This handing out of the numerous duplicates has been severely criticized by GoddIJ (1931) who held that all was done far too quickly and not with the greatest possible return. When looking at the correspondence at Utrecht, as well as at the Rijksherbarium, one cannot fail to notice, however, the great numbers of new plants which were received during Miquel's time. Although a strict numerical equality in exchange was observed between Utrecht and Leiden, this was not the case with other institutions. On the whole this worked out to the advantage of the Rijksherbarium: from Kew, for instance, much more material was received than given in exchange.

Miquel started work on these collections himself as well. He had been able to make it a condition that he would be allowed to publish the new results in a sumptuous folio journal, one of the very few of its kind, the Annales musei botanici Lugduno-batavi (207). Although Miquel is the author of many articles, we find several by others, namely Mettenius, Meisner, Schott, Hasskarl, C. Koch, R. Caspary, S. Kurz, Oudemans, P. de Boer, and Scheffer. The last two Dutch botanists were pupils of Miquel who took their doctor's degree with him. P. de Boer wrote a thesis in 1866 on the Conifers of the Malayan archipelago, starting off with the much disputed Pinus merkusii (for which Blume had substituted a nomen nudum from Wallich) and R. H. C. C. Scheffer wrote a thesis on the Malesian Myrsinaceae (1867). It was a constant source of regret to Miquel that he was not able to attract more pupils in botany. Scheffer went to the East Indies and, upon Miquel's recommendation, soon replaced the aged Teysmann ${ }^{28}$ ) as director of the Buitenzorg garden.

Miquel's personal interest was especially directed towards the numerous collections from Japan which he found in the Rijksherbarium. This resulted in a series of articles in the Annales, also separately published as the Prolusio florae japonicae (236). Japan, which had remained practically closed to botanical exploration by foreigners for 
such a long time, had a rich flora which was only very incompletely known. After Miquel's activity, the Japanese herbarium at Leiden was for some time the richest single named collection of that country outside Japan. The old Academy herbarium had a good set of Thunberg duplicates from Japan, received in van Royen's time. Other collections of prime importance for the knowledge of the Japanese flora were those made by von Siebold (1823-1829), Buerger (around 1830-1840), Textor (1842), Mohnike (1848-1852); some smaller collections had been made by American botanists (Morrow, Williams, Wight) and sent to Miquel by Asa Gray. Furthermore there were duplicates of Oldham's collections at Kew and of those made by Maximowicz from Leningrad. Miquel's contribution to the flora of Japan could thus be a fundamental one. It reflects in a special way the great rôle played by the Dutch in the first phases of the contacts between Japan and the western world. Thunberg, von Siebold, and Buerger alike had been on Dutch government missions, Miquel made his major contribution to the flora of Japan as director of the Rijksherbarium. It is characteristic that none of the four was Dutch by birth.

Thunberg and Zuccarini had already found some remarkable affinities between the floras of Japan and eastern North America, and Miquel elaborated this theme in 1867 in two articles $(257,258)$ based on the greatly increased material at his disposal. Miquel points out the new development started by Darwin who had "added a historical chapter to plant geography"'. Asa Gray had also studied this relationship between Japan and his own part of the world, and had further developed Darwin's hypothesis into a theory explaining the phenomenon of the many closely related but not identical species by common descent. "I do not follow my friend in this direction": Miquel was still a little hesitant to accept the Darwinian theory, but mainly because he wanted still more proof. With respect to the phenomenon of the identical species and genera he wholeheartedly agreed to assign to them a single origin: a polytopic explanation was in conflict with the basic scientific requirement to search for the simplest solution.

The fact that Miquel also studied the phenomenon of identical genera but with different species in Japan and America implies that he was after all not really so opposed to the Darwinian "hypothesis". $\mathrm{He}$ admits that in these numerous cases it is possible to suspect that the related species have a common origin and that they had become differentiated because of geographical isolation. We see therefore that Miquel, although hesitantly, goes along with the Darwinian theory very shortly after its publication.

\section{The last years}

During the last years of his life Miquel's health became worse and worse. It seems as if his working power increased under this pressure. We meet here again the phenomenon of the man who, consciously or subconsciously, sees his end approach and who still wants to give as much as possible. The articles follow each other in quick succession, the 
subjects dealt with vary greatly, and the style becomes more concise. There was so much to do and so little time left. How Miquel succeeded in combining the Leiden and Utrecht posts with this feverish scientific activity is a mystery. Even when one takes into account that the official duties were less heavy than they are to-day, it remains difficult to imagine how Miquel succeeded in constantly keeping up his scientific production. Mulder relates that Miquel seldom prepared his courses, and that he worked until only a few minutes before the appointed hour, to resume his writing again immediately after. There was, however, also a frequent correspondence with colleagues abroad and with the East Indies; there were the affairs of the Academy of Sciences, and, not least, the frequent visitors.

On 10 January 1866 Miquel was elected a foreign member of the Swedish Academy of Sciences, mainly through the intervention of his friend Nils Johann Andersson. Miquel occupied the chair that had become vacant by the death of one of the men he had most warmly admired during his whole career: Sir William Jackson Hooker. The other foreign botanical members were Martius, von Mohl, Brongniart, Alexander Braun, Asa Gray, Alphonse de Candolle, and J. D. Hooker. The composition of this group indicates in which high esteem Miquel was held internationally during the last years of his life. Andersson wrote to Miquel: "Wie Sie in Holland der erste gewesen und [sic] sind wie Hooker es in England war, das weiss die Welt".

In 1865, on the occasion of the Amsterdam Horticultural and Botanical Congress, many foreign botanists visited the Netherlands and met Miquel, some for the first time after a life-long correspondence. Meisner from Basel and Andersson from Stockholm stayed with Miquel at Utrecht. They were all deeply impressed by Miquel's family life, and perhaps especially by his elder daughters. At that time Miquel had a son, Anton, and three daughters, of which the eldest, Bertha, later founded the Miquel fund of the Utrecht University. We know little about Miquel's family life. There are only occasional remarks in the correspondence and Mulder's story simply confirms the general impression, gained from the letters of the visitors, of a very happy family.

In the letters of the last few years there are several indications that the end was near. There are, first, the frequent remarks on Miquel's condition, but there are also the plans for visits to other botanists that were made but never carried out.

On 4 May 1865 the aged Antoine Fée (1789-1874) wrote to Miquel, not suspecting that he himself would be the one to survive the other: "l'idée malheureusement trop probable que nous ne nous reverrons m'attriste et je veux l'écarter pour vous donner, le front épanoui, une cordiale embrassade".

On October 1869 Asa Gray was in London and the two men had hoped to meet again and to renew their acquaintanceship, dating from 1855 when Gray was in Amsterdam. Miquel planned to go to Kew and to join Gray and Hooker. A further set-back in his health prevented him from doing so. Sadly Gray wrote on 4 October: "now 
we may never meet again face to face". In 1870 Miquel stayed for a long time in Germany, to recuperate, but soon after his return he fell ill again. In January 1871 he took up his correspondence for the last time and wrote to Alphonse de Candolle (13 Jan.) "Nous avons regretté beaucoup d'avoir manqué la visite de $\mathrm{M}$. C. de Candolle et son épouse. Espérons à un temps plus heureux et pas si triste qu'à présent, où le vandalisme des Prussiens et de leur Roi barbare et orgueilleux font honte à la civilisation de notre époque. Le pauvre M. Fée, comme j'ai pitié de lui . .." Fée had fled from Strasbourg to Genève. Miquel had been deeply shocked by the outbreak of the Franco-Prussian war. To see the country which he admired so much, and to which he also owed a great deal of his inspiration as a scientist, in its mood of military aggression, deeply affected him.

On 20 January Miquel sent his annual report on the state of the Rijksherbarium to the government. On 23 January he died, 59 years old.

\section{Exilogue}

What strikes us most in the relatively short life of Miquel is his amazing productivity. The bibliography appended to this sketch of his life is the best testimony of his colossal activity. Miquel witnessed the development of the country in which he lived from a narrow, selfcentred, stagnant community which had all the characteristics of a stifling provinciality, to an open, progressive and dynamic society. In 1871 its industrial development was achieving its most spectacular results and the greatly increased facilities of communication stimulated not only the economy but also the minds of the people. Science had grown with society, and Miquel had been one of the builders of that new and changing world of thought which had succeeded the romantic aftermath of the previous century. Science, in the Netherlands as elsewhere, was no longer merely subservient to usefulness but had emerged as a human activity per se which had gained its conspicuous place in society on its own merits.

As a taxonomist, Miquel had made himself an international reputation. His work may show ups and downs, his enthusiasm for new forms and new perspectives may sometimes have led him to be a little over-hasty; these circumstances hardly detract, however, from his intrinsic merit for having laid the foundation for the study of the flora of Suriname, and for having greatly improved the state of knowledge of the Malesian and Japanese floras.

As a biologist, Miquel had an open mind for new developments. Being by nature conservative and somewhat handicapped in the appreciation of basic biological phenomena by his religious beliefs, it is remarkable how faithfully he adhered to the primacy of scientific discoveries over all other considerations.

As a politician of science, Miquel served his country conspicuously as a skilled diplomatist in the face of a persistent movement which made it a principle to separate scientific and state affairs. 
As a man Miquel comes forward from his correspondence, and from the testimonies of men who knew him, as a charming personality, full of stories, cheerful, positive, and sometimes almost charismatic in his effect on friends. In the Netherlands of his time Miquel may sometimes have felt a lack of opportunity, but the country was privileged to have in him one of the most influential and authoritative botanists of that stimulating and scientifically revolutionary nineteenth century.

\section{ACKNOWLEDGEMENTS}

Many persons and institutions helped me to assemble the material for this study. I am particularly indebted to the Directors and Staffs of the Conservatoire botanique at Geneve, the Gray Herbarium in Cambridge, Massachusetts, the Institut für systematische Botanik, and the Universitätsbibliothek of the Martin-LütherUniversität at Halle (Saale), the Swedish Academy of Sciences at Stockholm, and the Laboratoire de Phanérogamie du Muséum d'Histoire naturelle in Paris for the courteous and liberal way in which they placed at my disposal their collections of letters written by Miquel. I sincerely thank the Director and the Curator of Manuscripts of the Utrecht University Library for their willingness to let me consult at my ease their rich collection of letters received by Miquel from numerous scientists at home and abroad.

I am especially grateful to the Bureau of the Academy of Sciences at Amsterdam for their wholehearted co-operation and for opening the Academy's archives to me. In this respect $I$ also acknowledge with my sincere thanks the help and advice received from Dr M. A. Donk.

The Director of the Rijksherbarium gracefully admitted me to the archives entrusted to his care. I am, however, especially indebted to Dr C. G. G. J. van Steenis for his frank and just evaluation of Miquel's merits for Malesian botany; an evaluation which he has permitted me to use for this account.

Special thanks are due to Miss $\mathbf{H}$. de Wilde, librarian of the Botanical Museum, Utrecht, for finding Miquel's numerous publications, often at very short notice.

The general and lingustic advice, given by Dr H. W. Rickett, was, as always, invaluable. 


\section{AnNotated List of MiQuel's pubications}

Miquel was a prolific writer, and short notes or reviews from his hand were often published in the most unexpected places. For this reason some items may have been missed. Only one reprint (no. 288) has not been traced to its origins. On the other hand no attempt has been made to list all particulars of reprints from known sources.

The order in which the publications are listed here is chronological.

Reviews are listed under Rev.; here too no attempt at completeness has been made. The period of Miquel's life is one of feverish reviewing activity and only relatively few reviews add information or views of any importance.

The abbreviations used in the first lines of the paragraphs giving references (Ref.) are: MI (Auction catalogue library Miquel, J. L. Beyers 29 April 1871 Utrecht), NI (Nissen, Die botanische Buchillustration, 1951) and PR (Pritzel ed. 2). Other important sources of bibliographical details not always mentioned in each particular case are Rehder's Bradley Bibliography (1912-1918), Merrill and Walker's Bibliography of Eastern Asiatic botany (1938), Woodward's Catalogue of the British Museum (Nat. Hist.) (1903-1940), and the bibliography given by MatTHES (1872).

All letters sent to Miquel quoted in this list are at the University Library of Utrecht (ULU) unless otherwise indicated. The location of other letters is indicated by means of the abbreviations of the Index herbariorum. - The letter M stands for Miquel.

All items have been seen except when marked (n.v.).

Miquel was a director of a botanic garden during his entire professional career (1835-1871). In this capacity he issued annual seedlists (Rotterdam, Amsterdam, Utrecht) which have not been listed here.

1. [General editor H. G. van Hall] Flora Belgii septentrionalis, sive florae batavae compendium. Vol. II, plantas cryptogamicas continens.

Pars 1, Equisetaceae, Filices, Marsiliaceae, Lycopodiaceae, Musci et Hepaticae elaboratae studio Frid. ${ }^{1}$. Ant. ${ }^{1}$. Guil. ${ }^{1}$ Miquel, math. et phil. nat. et med. cand. et M. Is Dassen, Med. Stud. Edidit, emendavit atque praefatus est H. G. van Hall. Amsterdam, J. C. Sepp, 1832. Oct., pp. i-xvi, 1-227, indexes.

Pars 2 continens Lichenes quos elaboravit H. C. van Hall et Algas, quas eleboravit F. A. G. Miquel. Amsterdam, J. C. Sepp, 1840. Oct., pp. i-xii, 233-477, indexes.-Praefatio-Voorrede bij H. C. van Hall and F. A. W. Miquel, dated 1 Aug 1840. Algas on pp. 353-477. 
Note: Herman Christiaan van Hall, 1801-1874, professor of botany at Groningen; Michael Dassen, 1809-1852, Dutch physician and amateur botanist.

Dates: pars 1: 1832; pars: 2 Feb 1841 (letter van Hall to M. dated 14 Feb 1841 (ULU).

Ref.: MI 430, PR 3709 .

Oudemans, Ned. Kruidk. Arch. ser. 2. 2: 247-249. 1877.

2. Responsio ad quaestionem botanicam, a nobilissimo disciplinarum mathematicarum et physicarum ordine in academia Groningana anno CIDIDCCCXXX propositam: "Describatur germinatio plantarum, praemissa brevi disputatione de pertibus sive organis, quibus constat fructus, deque harum partium functione." Quae praemium reportavit. Groningen 1832. Qu., pp. 1-71. Also incorporated with same pagination in Annales Academiae Groninganae 18301831, publ. 1833.

Date: 1832.

Ref.: MI 415, PR 6254.

3. Dissertatio anatomico-physiologica inauguralis, exhibens veterum de jecore merita, quam, favente summo numine, ex auctoritate rectoris magnifici Jani ten Brink, ... submittit Fred. Anton. Guilielm. Miquel, Benthemensis. A.D. XV Maii CIDIDCCCXXXIII, Hora XI. Groningen, P. S. Barghoorn. Oct., pp. i-viii, 1-88, i-v, vitia typographica.

Date: 15 Mai 1833, available on date mentioned on title-page.

Rev.: Alg. Konst- en Letterbode 1833(2): 156-159. 30 Aug 1833, 172-175. 6 Sep 1833.

4. Responsio ad quaestionem botanicam, ab ordine disciplinarum mathematicarum et physicarum in academia lugduno-batava, A. MDCCCXXXII propositam: Qua quaeritur: "Organorum in vegetabilibus exponantur orbus, explicatio et successio, tum aliorum ex aliis, et in alia mutatio, quam metamorphosin sive prolepsin plantarum dicunt botanici. Respondentur huic quaestioni ita, ut rerum expositio plantarum exemplis illustretur, dein it virorum cll. Linné, Goethe, de Candolle, Agardh, Roeper, F. G. Gmelin et aliorum di eodem argumento sententiae et observationes haud negligantur'. Quae praemium reportavit, d. viii mensis Februarii, A. MDCCCXXXIII.-no place, no further date, no publisher, pp. 1-102, tt. i-ii. Qu.

Date: Published as a preprint in 1833 with an additional title-page, which reads: Commentatio de organorum in vegetabilis ortu et metamorphosi die viii mensis Febr. 1833 praemio ornata. Lugd. Bat. 1833. Included under this title in Annales Academiae Lugduni-Batavorum 1832-1833, publ. 1834.

Rev.: v. Hall, Tijdschr. nat. Gesch. Physiol. 1 (Boekbeschouwing): 227-234. 1834. Schlechtendal, Linnaea 9 (3, Litt.): 54. 1834, also in Alg. Konst- en Letterbode 1835 (1): 44-45. 16 Jan 1835.

Wigand, Kritik und Geschichte der Lehre von der Metamorphose der Pflanze. 1846.

Ref.: MI 435, PR 6255.

5. Iets over de literatuur der inlandsche flora. Alg. Konst- en Letterbode 1: 55-59. 24 Jan, 196-197. 21 Mar 1834. 
6. Aanteekeningen over de verdiensten van Rembert Dodoens omtrent de kennis der inlandsche planten. Tijdschr. nat. Gesch. Physiol. 1: 280-289. 1834.

Date: From a letter by v. Hall to M., dated 27 Feb 1835 , it is clear that the relevant fascicle of the $T_{i j d s c h r i f t}$ had by then been published only a short time ago. Reprints (s.l.n.d.) were prepared.

Ref.: MI 416.

\section{5}

7. Tentamen florae Homericae; of, Bijdragen tot de kennis der planten, die in de gedichten van Homerus voorkomen. [part II of:] F. A. W. Miquel en W. H. de Vriese, Bijdragen tot de geschiedenis der botanische wetenschap. Tijdschr. nat. Gesch. .Physiol. 2(2): 111-165. 1835. Also issued as a reprint.

Date: Reprints available on 1 Nov 1835 when M. sent a copy to Dierbach, who acknowledged receipt on 21 Mar 1836 (letter ULU).

Rev.: Beilschmidt, Jahresber. 1837: 301-302. 1841. Isis (v. Oken) $1840(5)$ : 348-354. Mai 1840. Fenaer Lit. Zeitung 1837(77) (n.v.).

German translation 1835, see no 13.

8. [review of Wikström,] Conspectus litteraturae botanicae in Suecia. Tijdschr. nat. Gesch. Physiol. 2 (Boekbeschouwingen):145-146. 1835.

9. [with G. J. Mulder] Over eene incrustatie van een anker, in zee gevonden. Natuur- en scheikundig Archief 3: 209-227. 1835.

\section{6}

10. [review of H. E. Richter] Codex botanicus Linneanus. Athenaeum, Tijdschr. Wet. Kunst 1(5): 530-533. Mai 1836.

Note: The authorship of this anonymous review is conjectural. Miquel did also other reviews for this journal.

11. De Noord-Nederlandsche vergiftige gewassen. Amsterdam, C. G. Sulpke, 1836. Oct., pp. 1-198, tt. 1-30. Preface dated Sep 1836.

Note: The publisher Sulpke bought some plates from Aimé Henry in Bonn, used for his book Die Giftpflanzen Deutschlands (PR 3971). A few other plates were made especially, by Henry, for Miquel's publication.

$\begin{array}{lcccc}\text { Dates: } & \text { part } & \text { pages } & \text { plates } & \text { dates } \\ & 1 & 1-80 & 1-8 & \text { Dec 1836 } \\ 2 & 81-112 & 9-16 & \text { Mar 1837 } \\ 3 & 113-144 & 17-24 & \text { Apr-Dec 1837 } \\ & 4 & 145-198 & 25-30 & \text { Apr-Dec 1837 }\end{array}$

These dates are based on letters by van $\mathrm{Hall}$ to Miquel; part I was announced as available by the Nieuwsblad voor den Boekhandel, 14 Dec 1836. On 15 Nov 1838 a second edition , ,2 $2^{\circ}$ verbeterde druk" was announced as available (n.v.).

Rev.: van Hall, de Recensent 30(16): 228-231. 1837 (fasc. 1), 31(13): 106-109. 1838 (fasc. 2-4).

Alg. Konst- en Letterbode 1836(2): 408-411 (rev. dated 23 Dec).

Ref.: MI 413, NI 1388, PR 6257 (no copy seen by Pritzel!). 
12. [review of H. C. van Hall,] Flora Belgii septentrionalis sive Florae batavae compendium. Vol. 1, pars 3. De Recensent 1836 (14): $148-152$.

Note: The review is unsigned but is by Miquel; see his letter to v. Hall of $4 \mathrm{Mai}$ 1836.

13. Homerische Flora. Aus dem Holländischen übersetzt von J. G. M. Laurent, ph. Dr., Altona, Johann Friedrich Hammerich, 1836. Oct., pp. viii, 70 .

Date: Jul-Nov 1836 [Mentioned in Gersdorf, Repertorium 10: 471-472. Nov 1836; preface dated Jun 1836].

Rev.: Jenaische Literatur Zeitung no. 77. Apr 1837 [n.v.], translated into Dutch in Alg. Konst- en Letterbode 1837(2): 330. 17 Nov 1837. Schlechtendal, Linnaea $11(6)$ (Litt.): 216-217. 1837.

\section{7}

14. Iets over het geslacht Zamia L. (Naar aanleiding van Prof. Lehmann, Novarum et minus cognitarum stirpium pugillus VI). Alg. Konst-en Letterbode 1837(1): 66-70. 3 Feb 1837.

15. Disquisitio geographico-botanica de plantarum regni-batavi distributione. Leiden, P. H. van den Heuvell, 1837. Oct., [viii], xxxii, 88 pp.

Date: Apr 1837 (Nieurwsblad Boekhandel 13 Apr 1837; letter v. Hall to M. 12 Apr, Lehmann to M. 18 Apr).

Rev.: Anon., Alg. Konst-en Letterb. 1837 (2): 71-75. 4 Aug 1837. Anon., Athenaeum, Tijdschr. Wet. Kunst 4(2): 97-103. Aug. 1837. Schlechtendal, Linnaea 11 (6) (Litt.): 214-216. 1837, Alg. Konst- en Letterb. 1838 (1): 75-76. 30 Jan 1838.

Beilschmied, Jahrb. wiss. Kritik 1838 (1): 551-564. Apr 1838.

Ref.: MI 410, PR 6258.

Oudemans, Ned. Kruidk. Arch. ser. 2. 2 : 250.1877.

16. [review of C. G. Nees ab Esenbeck] Systema Laurinarum. Athenaeum, Tijdschr. Wet. Kunst 3(4): 322-326. Apr 1837.

17. Echinocacti novi descriptio, adjectis de Melocacti et Echinocacti speciebus quibusdam animadversionibus. Linnaea 11(2): 153-161. t. iv. 1837.

Date: Apr-Jun 1837. Heft 2 of vol. 17 of Linnaea, as well as the reprints, were received by Miquel between 31 Mar and 27 Jun 1837 (dates of letters to Schlechtendal, HAL). Heft 2 was not yet ready on 15 Mar (letter Schlechtendal to M.). Reprints not seen.

Ref.: MI 414.

18. Melocactorum duorum novorum descriptio. Linnaea $11(6): 641-$ 647. 1837.

Date: Aug-Dec 1837 (M. submitted his article to Schlechtendal on 27 Jun, letter HAL).

19. Over het Sargasso of zeekroos. Tijdschr. nat. Gesch. Physiol. 4(1): 25-41. 1837. 
Date: Sep-Dec 1837 (part 1 carries date Sep 1837 on p. 208).

Rev.: Isis (v. Oken) 1840(5): 372-374. Mai 1840.

Linnaea 15 (Litt.): 165.1841.

Frorieps Neue Not. 5: 259 (n.v.).

20. Proeven over de werking van vergiften op planten. Tijdschr. nat. Gesch. Physiol. 4(1): 154-208. 1837.

Date: Sep-Dec 1837 (cf. no. 19; dated Sep 1837 on p. 208).

Rev.: Linnaea 15 (Litt.): 165-166. 1841.

21. Proeven over den invloed van het licht op de water-exhalatie der groene plantendeelen, en het opnemen van water door de stengen. Athenaeum, Tijdschr. Wet. Kunst 4(5): 389-402. Nov 1837.

French version: see under no. 35 .

22. [Botanische Notiz] Flora 20: 717-719. 7 Dec 1837.-On watersecretion by Arum colocasia L., already reported by Abraham Muntingh.

23. Stigma Salviae pratensis L. fl. albis cum labio infer. coalitum. Linnaea 11(5): 607.1837.

\section{8}

24. [co-editor] Bulletin des sciences physiques et naturelles en Néerlande, rédigé par F. A. W. Miquel, G. J. Mulder et W. Wenckebach.

Année 1838, Leiden, $196 \mathrm{pp}$. Qu., published in 25 parts of 8 pages each (except no. 25 which has 4 pages) all dated.

Année 1839, Leiden, 468 pp. Oct. [sic], published in 6 parts which are not separately dated, but of which nos. 1-5 appeared in 1839 , no. 6 in 1840 .

Année 1841,378 pp. Oct. no title-page, no contents, no division into fascicles in copies consulted.

25. Note additionelle sur une autre espèce du même genre [i.e. Encephalartos]. Bull. Sci. phys. nat. Neérl. 1838: 11-12. 1 Feb 1838.

Rev.: Linnaea 12 (Litt.) : 245. 1838.

26. De Noord-Nederlandsche vegetatie in hare hoofdtrekken vergeleken met die der Pruissische Rijn-provincie. Tijdschr. nat. Gesch. Physiol. 4(3): 271-281. 1838.

Date: Feb 1838-The article is dated Oct 1837, but the first report of its availability is from $28 \mathrm{Feb} 1838$ on which date Marquart acknowledges receipt of a copy of the reprint in a letter to $M$.

Rev.: Linnaea 15 (Litt.): 166. 1841.

French abstract: Comparaison générale de la flore néerlandaise avec celle de la province Rhénane de Prusse, Bull. Sci. phys. nat. Néerl. 1838: 149-152. 15 Oct 1838.

27. Plantas cacteas novas et minus cognitas describit Fr. A. Guil. Miquel. Linnaea 12: 1-20. $2 \mathrm{tt}$. (15 figs.). 1838.

Date: Feb 1838 [M. received the reprints on or before 7 Mar 1838 (letter M. to Schlechtendal 7 Mar, HAL; letter S. to M. 10 Mar)]. 
28. Note sur une nouvelle espèce de Draparnaldia. Bull. Sci. phys. nat. Néerl. 1838: 18-19. 15 Feb 1838.

Rev.: Linnaea 12 (Litt.): 245.1838.

29. Notice sur le Sargasse de l'Océan. Bull. Sci. phys. nat. Néerl. 1838: 19-22. 15 Feb 1838.

Note: Extract of no. 19 from 1837.

Rev.: Linnaea 12 (Litt.): 246. 1838.

30. Observation sur le canal médullaire et les diaphragmes du tronc de Cecropia palmata L., suivie de considérations générales sur les diaphragmes médullaires. Première partie. Bull. Sci. phys. nat. Néerl. 1838: 29-31. 28 Feb 1838.

Idem, dernière partie. Bull. Sci. phys. nat. Néerl. 1838: 168. 15 Nov 1838, 169-172. 30 Nov 1838.

Rev.: Linnaea 12 (Litt.): 246. 1838 (part 1).

31. Plantarum cactearum, in Flora fluminensi delineatarum, revisio. Bull. Sci. phys. nat. Néerl. 1838: 47-48. 31 Mar 1838, 49. 15 Apr 1838.

Rev.: Linnaea 12 (Litt.): 247. 1838.

32. Observations sur les Cycadées de l'herbier royal à Leyde. Bull. Sci. phys. nat. Néerl. 1838: 82-85. 15 Jun 1838.

Rev.: Linnaea 12 (Litt.): 248.1838.

33. Notice sur une espèce nouvelle d'Isaria du Brésil. Bull. Sci. phys. nat. Néerl. 1838: 85-86. 15 Jun 1838.

Reo.: Linnaea 12 (Litt.) : 248. 1838.

34. Remarques sur le parasitisme du Tillandsia aloaefolia Hook. Bull. Sci. phys. nat. Néerl. 1838: 86-88. 15 Jun 1838, 89-90. 30 Jun 1838.

Rev.: Linnaea 12 (Litt.): 249. 1838.

35. Quelques expériences pour déterminer l'influence de la lumière sur l'exhalaison aqueuse des feuilles et sur la suction par les tiges des plantes. Bull. Sci. phys. nat. Néerl. 1838: 99-104. 15 Jul 1838.

Abstract: Ann. Sci. nat. Bot. ser. 2. 11 : 43-48. Jan 1839; Dutch version cf. no. 21.

36. Proeven over de prikkelbaarheid der bladen van Mimosa pudica L. genomen door F. A. W. Miquel. Tijdschr. nat. Gesch. Physiol. 5 (1): 35-60. 1838.

Date: Aug-Dec 1838.

Reo.: Meyen, Arch. Naturgesch. 5 (2): 89-91. 1839, translated in Revue physiologique 1838 (no. 12, n.v.) and Ann. Sci. nat. Bot. ser. 2. 13. Mai 1840.

Beilschmidt, Jahresber. 1838: 356-357. 1843.

Isis (v. Oken) 1840 (5) : 390-391. Mai 1840.

Translations: Recherches sur l'irritabilité des feuilles de la sensitive (Mimosa pudica L.). Bull. Sci. phys. nat. 1839 (4): 284-299. 1839; Untersuchungen über die Reizbarkeit der Blätter von Mimosa pudica L. Arch. Naturgesch. 5 (1): 91-105. 1839 . 
37. Uber die Präfoliation der Cycadeen. Flora 1838: 499-503. 21 Aug 1838.

38. Note sur la préfoliation des Cycadées. Bull. Sci. phys. nat. Néerl. 1838: 129-130. 15 Sep 1838.

Abstract: Ann. Sci. nat. Bot. ser. 2. 11: 61-62. Jan 1839, German version: no. 37.

39. Expériences sur l'action des substances vénéneuses sur les végétaux. Bull. Sci. phys. nat. Néerl. 1838: 137-143. 30 Sep 1838, 160. 31 Oct. 1838, 161-163. 15 Nov 1838.

French version of no. 20.

40. Beleuchtung des Geschlechtes Encephalartos Lehm. Allg. Gartenzeitung (Otto et Dietrich) 6:321-326. 13 Oct 1838.

41. Note sur le fruit de l'Amomum granum paradisi. Bull. Sci. phys. nat. Néerl. 1838: 157-159. 31 Oct 1838.

42. Observatio de caulium et foliorum in quibusdam Euphorbiis metamorphosi. Flora 1838: 649-657. 7 Nov 1838.

43. Sur une espèce nouvelle d'Isaria du Brésil. Ann. sci. nat. Bot. ser. 2. 10: 377-378. Dec 1838.

Note: extracted from no. 33.

44. Leerboek tot de kennis der Artsenijgewassen, derzelver zamenstelling, krachten, gebruik en pharmaceutische bereidingen. Amsterdam, C. G. Sulpke, 1838. Oct., xvi pp. [voorrede], xliv pp. [inleiding], 406 pp.Voorrede p. xvi dated Mai 1838; half title-page reads: Beschrijuing der artsenijgewassen volgens de natuurlijke rangschikking. Dedicated to $\mathrm{C}$. L. Blume and I. G. C. Lehmann.

Date: Dec 1838 (copy sent to v. Hall 18 Dec 1838, letter ULU).

Rev.: Alg. Konst-en Letterbode 1839: 153-156. 30 Aug 1839.

Second edition: see no. 181, 1859.

Ref.: MI 408, PR 6259.

45. Note sur l'Encephalartus horridus Lehm. et sur ses différentes formes. Ann. Sci. nat. Bot. ser. 2. 10:366-369. Dec 1838.

46. [unsigned review of C. L. Blume,] Rumphia ...Tom. 1. Bull. Sci. phys. nat. Néerl. 1838: 183-190. 15 et 31 Dec 1838.

47. Flora batava of afbeelding en beschrijuing van Nederlandsche gewassen, door J. Kops en F. A. W Miquel, afleveringen 118-125, Amsterdam, J. C. Sepp en Zoon, 1838. Qu.

Note: The fascicles contain the following plates: 118: 601-605, 119: 606-610, $120: 611-615,121: 616-620,122: 621-625,123: 626-630,124: 631-635,125$ : $636-640$.

These fascicles are part of volume 8 of Jan Kops' Flora batava, dated 1836, containing parts 113-128, plates 561-640. Parts 113-117 were edited by H. C. van Hall, parts 126-128 were edited by J. E. van der Trappen.

Rev.: Beilschmied, Jahresbericht 1838: 154. 1843.

Ref.: MI 432, NI 2247, PR 4822.

Oudemans, Ned. Kruidk. Arch. ser. 2. 2: 239-244. 1877. 
48. Nadere toelichting omtrent den aard en oorsprong van het Zee-kroos. Tijdschr. nat. Gesch. Physiol. 5(4): 321-331. 1839.

Rev.: Isis (v. Oken) 1840(5): 395. Mai 1840.

49. Commentarii phytographici, quibus varia rei herbariae capita illustrantur. Fasciculus I. Commentatio de vero Pipere Cubeba deque speciebus cognatis ac cum eo commutatis, qui praemissa est disputatio taxonomica et geographica de Piperaceis. Leiden, S. et J. Luchtmans, 1839. Fol., pp. i-iv, 1-29, tt. $i-i i i$.

Date: Feb 1839 [p. 29 dated Nov 1838; copy sent to W. J. Hooker on 6 Feb 1839 (letter at K), copy received by Meisner on 14 Mar 1839 (letter ULU), announced in Flora 28 Mai 1839; Nieuwsblad Boekhandel 21 Feb 1839.].

Rev.: Liter. Zeitung no. 39, 25 Sep 1839 (n.v.), translated Alg. Konst- en Letterbode 1840(1): 122-123. $21 \mathrm{Feb} 1840$.

Isis (v. Oken) 1840: 497-499. Jul 1840.

Fasciculus II. Observationes de Piperaceis et Melastomaceis. Leiden, S. et J. Luchtmans, 1840. Fol., pp. i-iv, 31-92, tt. iz-xi.

Date: Jan-Mai 1840 (rev. Liter. Zeitung 17 Jun 1840).

Rev.: Liter. Zeitung no. 25, 17 Jun 1840 (n.v.), translated Alg. Konst- en Letterbode $1840(2): 30-31$. $10 \mathrm{Jul} 1840$.

Isis (v. Oken) 1840: 497-499. Jul 1840.

Fasciculus III. Sylloge plantarum novarum vel minus cognitarum ex ordinibus Araliaceartm, Cactearum, Hypoxidearum, Cycadearum et Urticacearum. Leiden, S. et J. Luchtmans, 1840. Fol., pp. i-iv, 93-146, tt. xii-xiv.viii pages of introductory matter [title-page, dedication to $S$. Endlicher, praemonendum] were supplied with fasc. iii, the title-page being dated 1838-1840, p. vii dated Dec 1840.

Date: Dec 1840 or Jan 1841 [Meisner received a copy on 2 Feb 1841 (letter ULU); the booksellers Luchtmans, in a list of their 1840 publications (at $U$ ) list only fasc. 2 for 1840.

Plates: Uncoloured lithographs after drawings by Miquel (i, ii, iv, viii, $\mathbf{x}$ ) and Q.M.R. Ver Huell (iii, v, vi, vii, ix, xii, xiii, xiv).

Ref.: MI 407, NI 1384, PR 6260.

50. Mélanges botaniques. Bull. Sci. phys. nat. Néerl. 1839: 37-48. [Mar-Apr] 1839.

Rev.: Linnaea 14 (Litt.): 255-256. 1840.

Isis (v. Oken) 1840(5): 403. Mai 1840.

Reprinted from this article: (1) Observations sur les Cycadées. Ann. Sci. nat. Bot. ser. 2. 14: 60-62. Jul 1840; (2) Sur la germination des Melocactus, Ann. Sci. nat. Bot. ser. 2. 14: 62-63. Jul 1840.

51. Genera cactearum descripta et ordinata, quibus praemissi sunt characteres totius ordinis et adfinitatum adumbratio. Rotterdam, Adolph Baedeker, 1839. Oct., pp. ii, 32.

Date: probably Jun-Jul 1839 [Miquel forwarded a copy to Meisner on 13 Jul, fide letter Meisner of 31 Jul (ULU); presented to Regensburg botanical society before 5 Aug 1839, cf. Flora 1839; 542); the article is dated Jan 1839]. 
Note: Reprinted with separate pagination, separate title-page, and different title from Bull. Sci. phys. nat. Néerl. 1839(2): 87-118. This fascicle was published after Mai 1839. The title of the article in the journal is "Genera cactearum exposuit F. A. W. Miquel".

52. Untersuchungen über die Reizbarkeit der Blätter von Mimosa pudica L. Arch. Naturgesch. 5 (1): 91-105. 1839.

Note: German translation of no. 36 .

53. De Encephalarto horrido Lehm. ejusque formis scripsit. Tijdschr. nat. Gesch. Physiol. 6(1): 94-105. 1839.

Latin version of no. 45.

54. Note sur l'Encephalartos lanuginosus Lehmann. L'Horticulteur universel, Fourn. gén. jardiniers amateurs [ed. C. Lemaire] 1: 273. 1839.

55. Remarques servant à illustrer l'histoire et la nature du Sargasse de l'Océan. Bull. Sci. phys. nat. Néerl. 1839(3): 198-200.

Rev.: Linnaea 14 (Litt.): 258.1840.

Note: French version of no. 19.

56. Recherches sur l'irritabilité des feuilles de la sensitive (Mimosa pudica L.). Bull. Sci. phys. nat. 1839 (4): 284-299.

Note: French translation of no. 36.

57. Note préliminaire sur les genres de la famille des Pipéracées. Bull. Sci. phys. nat. Néerl. 1839(6): 446-453. [Jan-Jun] 1840; Ann. Sci. nat. Bot. ser. 2. 14: 167-172. Sep 1840.

58. Note sur quelques plantes cellulaires nouvelles. Bull. Sci. phys. nat. Néerl. 1839(6): 453-457. 1840 [Jan-Jun].

59. Remarques sur les genres Othera et Orixa de Thunberg. Bull. Sci. phys. nat. Néerl. 1839(6): 457-463 1840 [Jan-Jun].

60. Sur la germination des Melocactus. Ann. Sci. nat. Bot. ser. 2. 14: 62-63. Jul 1840.

Note: Part of Mélanges botaniques, cf. no. 50.

61. Observations sur les Cycadées. Ann. Sci. nat. Bot. ser. 2. 14:60-62. Jul 1840.

Note: part of Melanges botaniques, cf. no. 50.

62. Monographia generis Melocacti. Nov. Act. Acad. Nat. Cur. 18, suppl. 1: 81-200. tt. $i-x i .1841$. 
Date: The reprint was apparently available in Sep 1840. Reinwardt acknowledges the receipt of a copy on 5 Sep 1840 (letter ULU), Decaisne on 19 Oct 1840 (letter ULU). The preface is dated Dec 1838, the complete supplement volume is dated 1841 .

Rev.: Flora 25 (Lit. no. 1): 3-9.1842.

Plates: Lithographs, some colored, after drawings by Miquel, Ver Huell and several others.

Ref.: NI 1387, PR 6262.

63. Sur les bourgeons des Cycadées. Bull. Sci. phys. nat. Néerl. 1839 (6) : 463-465 [Jan-Jun] 1840, Ann. Sci. nat. Bot. ser. 2. 14: 363-364. Dec 1840.

64. Observatio de generibus Piperacearum. Ann. Sci. nat. Bot. ser. 2. 15: 285-288. Mai 1841.

65. Ein Wort über die Pilzgattung Bryomyces. Flora 24: 321-322. 7 Jun 1841.

Commentary: Karl Müller, Flora 24: 561-564. 29 Sep 1841.

66. Monographia Cycadearum. Utrecht, R. Natan, 1842. Fol. ii, 82 pp., viii tt.

Date: Jan 1842 [advertisement in Flora 25: 112, 21 Feb 1842 "Anfangs Januar ist in meinem Verlage erschienen ...". Miquel sent copies to Adr. Jussieu and Ad. Brongniart in Dec 1841 (letter P), other copies were sent to Delessert (acknowledged 11 Mar 1842) and Kunze (acknowledgement 10 Mar 1842) (letters ULU).

Note: Dedicated to Ad. Brongniart and Q. M. R. Ver Huell. Brongniart's copy of Dec 1841 must have been one of the first to be available.-For a contemporary comment see W. H. de Vriese, Tijdschr. nat. Gesch. Physiol. 10 (1): 57-67. 1843 .

Plates: uncolored lithographs after drawings by Ferdinand Bauer (i, ii, iii, iv, v), Miquel (i) and Ver Huell (ii, vi, vii, viii).

Ref.: NI 1386, PR 6264.

67. Gedachten over het onderwijs in de botanie, voor Genees- en Artsenijkundigen. Bijdragen tot Geneeskundige Staatsregeling 2: 16-22. [Jan-Jun] 1842.

68. Observationes de quibusdam Bignoniaceis surinamensibus. Flora 25: 424-431. 21 Jul 1842.

69. Antwoord aan den Heer H. C. van Hall. Alg. Konst- en Letterbode 1842 (2) : 275-278. 21 Oct 1842.

Note: A reaction by Miquel on criticism by van Hall in the same journal (1842 (2): 210-215) on the botanical training of medical students. See no. 67. 
70. Anatomische Bemerkungen über den Bau der Melocacten. Linnaea 16(5): 465-474. 1842.

Date: Dec 1842 (on p. 512 of this part of Linnaea a paper dated Sep 1842; reprints and Linnaea Heft were sent to Miquel by Schlechtendal on 5 Dec 1842, letter ULU).

71. Epistola de novo fungorum entophytorum genere quam Academiae praesidi (die XX Julii a. MDCCCXXXVIII) scripsit Fr. A. Guil. Miquel, A.C.N.C.S. Nov. Act. Acad. Nat. Cur. 19 (2): 161-168. t. lv. 1842.

Date: Probably not available before 1842 notwithstanding the early date of writing. Reprints were made with the date 1842 (n.v., cf. MI 405).

Plate: anonymous, lithographed, coloured.

\section{3}

72. Observationes de quibusdam plantis surinamensibus. Ann. Mag. nat. Hist. 11: 12-16. Jan 1843.

Date: Jan 1843. Pages 1-80 constitute the January number (cf. p. 1). From contemporary references and from the dates of receipt of the Annals by the University Library Cambridge (cf. accession registers) it is known that at this period the numbers were indeed issued in the months for which they were intended.

73. Remarques sur la structure anatomique des Melocactus. Ann. Sci. nat. Bot. ser. 2. 19: 164-176. Mar 1843.

Note: translation of no. 70 (1842).

74. De Cycadeis Loddigesianus, epistola ad Vir. Gl. G. H. de Vriese quam scripsit Fr. Ant. Guil. Miquel. Tijdschr. nat. Gesch. Physiol. 10(1): 68-74. 1843.

Date: probably Mar-Mai 1843 (p. 96 of fasc. 1 is dated 3 Mar 1843; Miquel's paper is dated Nov 1842; it was published before the French abstract "Description d'une nouvelle espece de Zamia" in Ann. Sci. nat. Bot. ser. 2. 19: 316-317. Mai 1843.

75. Animadversiones in herbarium Surinamense, quod in colonia Surinamensi legit H. C. Focke. Tijdschr. nat. Gesch. Physiol. 10(1): 75-93. 1843.

Date: probably Mar-Mai 1843 [last page of part 1 (p. 96) of journal dated 3 Mar 1843. The article itself is dated Nov 1842].

Reprints without title-page are mentioned by Rehder (Bibl. $1: 339$ ).

76. Ueber einige Pflanzen aus Surinam. Linnaea 17(1): 58-74. 1843. Date: probably Apr-Mai 1843 [Linnaea $17(1)$ was probably published in the second half of April or in May 1843. On 12 Apr Schlechtendal wrote to Miquel (letter ULU) that it had been printed and would soon be sent ('sehr bald')].

77. Lijst der planten, welke in de kolonie Suriname gekweekt worden; samengesteld door Mr. H. C. Focke, Lid van het Geregtshof te Paramaribo, medegedeeld door F. A. W. Miquel. Tijdschr. nat. Gesch. Physiol. 10 (4): 373-385. 1843. 
Date: Oct-Dec 1843 [fasc. 4 was for the last quarter of the year; the accompanying "Boekbeschouwingen" carry the date 25 Sep 1843 on p. 195]. Reprints exist, s.l.n.d. fide MI 425.

78. Systema piperacearum. Rotterdam, H. A. Kramers, 1843. Oct., iv, 575 pp.

Dates: fasc. 1, pp. i-iv, i-304. Dec 1843 or first week of Jan 1844. fasc. 2, pp. 305-575, 4 Apr 1844.

Note: The book is dedicated to Benjamin Delessert, who acknowledged the receipt of six copies [of fasc. 1] on 11 Jan 1844 [ULU]. The Bot. Zeitung of 9 Feb 1844 (p. 111) carried an advertisement "so eben erschienen". Meisner acknowledged receipt of a copy on 20 Feb 1844 [letter ULU]. Part 2 was announced for Mar 1844 on the cover of part 1. The first mention of it is in the Nieuwsblad voor den Boekhandel (4 Apr). Preface dated 1 Aug 1843.

Rev.: Schlechtendal, Bot. Zeitung 2: 157. 1 Mar 1844 (fasc. 1), 2: 604. 16 Aug 1844 (fasc. 2), translated Alg. Konst- en Letterbode 1845(1): 169-170. W. J. Hooker, London Journ. Bot. 4: 33-34. Jan 1845, translated Alg. Konst- en Letterbode 1845(1): 168-169.

79. Sertum exoticum contenant des figures et descriptions de plantes nouvelles ou peu connues; publié par F. A. W. Miquel. Première livraison. Rotterdam, H. A. Kramers, 1843. Qu., pp. 8, tt. 5.

Note: p. [1] constitutes the title-page for Tome 1, with the same text as given above but the date 1842 ! The reviews dating from 1843 and 1844 it seems best to assume 1843 as the actual year of publication. Nothing was published beyond livr. 1 .

Rev.: Karl Müller, Bot. Zeitung 2: 169. 8 Mar 1844.

Leipziger Repert. 1(4): 252-253. 15 Nov 1843.

Plates: The five uncoloured lithographs are after drawings by Q.M.R. Ver Huell. Ref.: MI 402, NI 1390, PR 6263.

v. Steenis-Kruseman, Fl. males. Bull. 3 : 644.1959.

80. Genre nouveau de la famille des Urticacées. Herb. gén. de l'Amateur ser. 2. 3 (Misc. bot.) : 18.1843.

Note: Not seen, cf. Merrill and Walker, Bibl. p. 324. A republication of the text and plate Splitgerbera japonica from no. 49 (Comment. Phytogr. 133-136. t. 13. $1840)$.

81. Nouveau genre de la famille des Araliacées. Herb. gén. de l'Amateur ser. 2.3 (Misc. bot.): 17.1843.

Note: Not seen, cf. Merrill and Walker, Bibl. p. 324. Contains the text and plates of Dimorphantus from Comment. Phytogr. 93-102. t. 12. 1840.

82. Piperaceae, [in F. J. F. Meyen,] Observationes botanicas, in itinere circum terram institutas. Nov. Act. Acad. Nat. Cur. 16, suppl. 2 [which is at the same time vol. 19, suppl. 1]: 483-495. 1843.

Notes: This volume constitutes Theil IV of Meyen's Reise um die Erde, Berlin 1834-1843, under the separate title Beiträge zur Botanik (pp. 32, 512, tt. 13). The volume was published posthumously (Meyen died in 1840) and contains in addition to a biography, botanical articles by twelve different authors.The 'Vorerinnerung' on $\mathrm{p}$. xii is dated 8 Nov 1842.--Reprints were prepared (not seen): Matthes' bibliography (1872) lists "Piperaceae Meyenianae $1843^{\prime \prime}$. 
83. Observationes botanicae de quibusdam plantis, quas in colonia Surinamensi legit vir. graviss. H. C. Focke. Het Instituut [2] 1842: 185-205. tt. 3. 1843.

Date: 1843 [title-page; the volume is for 1842, publ. 1843; Miquel's paper is dated Oct 1842 on p. 205; reprints (n.v.) also carried the date 1843 (cf. MI 401)].

84. Over eenige nieuwe geslachten uit de familie der Piperaceën. Het Instituut [2] 1842: 80-84. 1843.

\section{4}

85. Fragmenta phytographica. Ann. Sci. nat. Bot. ser. 3. 1: 31-41. Jan 1844.

Rev.: Bot. Zeitung 3: 156. 7 Mar 1845.

86. Genera et species Cycadearum viventium. Linnaea 17(6) : 675744. 1844.

Date: Apr-Jun 1844 or even somewhat later. Miquel's paper is dated Jan 1844. On 29 Mar 1844 Schlechtendal informs Miquel (letter ULU) that the article has been printed for the greater part and that Heft 6 will appear as soon as the plates and the register are ready. (see also Appendix I, p. 90).

87. Beyeria, novum genus Euphorbiacearum. Ann. Sci. nat. Bot. ser. 3 . 1. 350-352. t. 15. Jun 1844 .

88. Plantae surinamenses novae. Linnaea 18(1): 23-31. 1844.

Date: 24-26 Oct 1844 (for dates Linnaea see Appendix I, p. 90).

89. Observationes de plantis Novae Hollandiae et Novae Zeelandiae. Pugillus primus. Linnaea 18(1): 83-95. 1844.

Date: 24-26 Oct 1844 (for date Linnaea 18(1) see Appendix I, p. 90).

90. Symbolae ad floram surinamensem. [a series of articles in] Linnaea vols. 18, 19, 21 and 22.

$\begin{array}{cccc}\text { Pars Symb. } & \text { Linnaea vol./Heft } & \text { pages } & \text { date of publ. } \\ \text { I } & 18(1) & 49-82 & \text { 24-26 Oct } 1844 \\ \text { II } & 18(2) & 225-240 & \text { Nov 1844-Feb 1845 } \\ \text { III } & 18(2) & 241-256 & \text { Nov 1844-Feb 1845 } \\ \text { III ctd. } & 18(3) & 257-271 & \text { Nov 1844-Jul 1845 } \\ \text { IV } & 18(3) & 272-301 & \text { Nov 1844-Jul 1845 } \\ \text { V } & 18(3) & 353-384 & \text { Nov 1844-Jul 1845 } \\ \text { VI } & 18(5) & 563-624 & \text { Mai-Dec 1845 } \\ \text { VII } & 18(6) & 735-756 & \text { Jul-Dec } 1845 \\ \text { VIII } & 19(1) & 125-128 & \text { Jan 1846 } \\ \text { VIII ctd. } & 19(2) & 129-145 & \text { Feb 1846 } \\ \text { IX } & 19(2) & 221-233 & \text { Feb 1846 } \\ \text { X } & 21(4) & 473-479 & \text { Aug 1848 } \\ \text { XI } & 22(2) & 169-176 & \text { Jun 1849 } \\ \text { XII } & 22(4) & 465-476 & \text { Aug 1849 }\end{array}$

Notes: For the dates of the various issues of Linnaea see Appendix I, p. 90. Reprints were issued without cover and without additional imprint. The preface to the Symbolae [Linnaea 18(1):50] is dated Mai 1844 . 
91. Addenda ad synopsin Cycadearum viventium. Linnaea 18(1): 96-98. 1844.

Date: 24-26 Oct 1844 (for dates of Linnaea see Appendix I, p. 90).

92. Ueber den Bau eines erwachsenen Stammes von Cycas circinalis. Linnaea 18(2): 126-144. tt. 4-6. 1844.

Date: Nov 1844-Feb 1845 [for dates Linnaea see Appendix 1, p. 90). Reprints were available before $28 \mathrm{Feb} 1845$, date of acknowledgement receipt by Adr. Jussieu (letter ULU)].

Translation: for French translation see no. 101.

93. Bemerkungen über Schlegelia und über die Verwantschaften der Crescentieen Endl. Bot. Zeitung 2: 785-789. 15 Nov 1844, 801-806. 22 Nov 1844.

\section{5}

94. Pterisanthus cissoides Bl. illustratio. Linnaea 18(4):385-397. 1845. Date: Feb-Aug 1845 (for dates Linnaea see Appendix I, p. 90).

95. [various families in J. G. C. Lehmann,] Plantae Preissianae sive enumeratio plantarum quas in australasia occidentali et meridionali-occidentali annis 1838-1841 collegit Ludovicus Preiss. Hamburg, Meissner, vol. 1, 1845 , viii and 647 pp., vol. 2, 1846-1847, vi and $499 \mathrm{pp}$.

Contributions by Miquel are:

\begin{tabular}{|c|c|c|c|}
\hline Family & vol. and part & pages & date \\
\hline Zygophylleae & $1(2)$ & $164-165$ & 9-11 Feb 1845 \\
\hline Sapindaceae & $1(2)$ & $223-228$ & 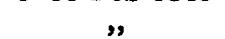 \\
\hline Olacineae & $1(2)$ & 228 & ", \\
\hline Malvaceae & $1(2)$ & 238-242 & " \\
\hline $\begin{array}{l}\text { Loranthaceae } \\
\text { Avicennieae }\end{array}$ & $1(2)$ & $\begin{array}{c}279-282 \\
353\end{array}$ & 14-16 Ảug 1845 \\
\hline Santalaceae & $1(4)$ & $608-619$ & $3-5$ Nov 1845 \\
\hline Casuarineae & $1(4)$ & $639-643$ & " \\
\hline Cupreninae & & $643-645$ & $\cdots$ \\
\hline
\end{tabular}

Note: The Börsenblatt für den Deutschen Buchhandel of 24 Sep 1844 announces the publication of "fasc. 1, 2". In view of the subsequent announcement of fasc. 2 in February 1845 and of the circumstance that Lehmann sent only fasc. 1 to W. J. Hooker on 1 October 1844 (letter at K) and to Miquel on 29 September, it may be assumed that it was only fasc. 1 which was issued in September. The dates given here for fascicles 2,3 , and 4 are also those of receipt at Leipzig as recorded by J. G. Hinrichs in the Börsenblatt; fasc. 1 of vol. I was received between 19 and 21 September 1844; fasc. 1 of vol. 2 was received between 26 and 28 Nov 1846. These dates of receipt at Leipzig can be taken as the dates of effective publication. In a few instances the book may have been available somewhat earlier in the actual town of publication but this difference will mostly be irrelevant.

Ref.: PR 5176

Stearn, Journ. Soc. Bibliogr. nat. Hist. 1: 203-205. 1939. v. Steenis-Kruseman, Flora males. ser. 1. 4: cxcvi. 1954. Börsenblatt für den Deutschen Buchhandlung 24 Sep 1844 (fasc. 1), 14 Feb 1845 (fasc. 2); 19 Aug 1845 (fasc. 3), 7 Nov 1845 (fasc. 4). 
96. Observationes de ovulo et embryonibus Cycadearum. Ann. Sci. nat. Bot. ser. 3. 3: 193-206. tt. 8-9. Apr 1845.

Plates: The two uncoloured plates are lithographs after drawings by Miquel. Rev.: Bot. Zeitung 6: 134. 18 Feb 1848.

Ref.: MI 400 (reprints).

97. De Phenakospermi, Musacearum generis, charactere botanico. Bot. Zeitung 3: 345-347. 23 Mai 1845.

98. Animadversiones in Piperaceas herbarii Hookeriani. London Journ. Bot. 4: 410-470. Jul-Sep 1845.

Rev.: Bot. Zeitung 4: 226. 27 Mar 1846.

Note: $40-50$ reprints were made (n.v.) but had not yet been sent to Miquel by 15 Dec 1845 (letter J. D. Hooker to M.)

99. Observationes de quibusdam Piperaceis herbarii Schlechtendaliani. Linnaea 18(6): 710-716. 1845.

Date: Jul-Dec 1845 (for dates Linnaea see Appendix I, p. 90).

Rev.: Bot. Zeitung 16 Jan 1846.

100. Annotatio observationibus de ovulo Gycadearum addenda. Ann. Sci. nat. Bot. ser. 3. 4: 79-80. Aug 1845.

Ref.: Bot. Zeitung 6: 178. 3 Mar 1848.

101. Recherches sur la structure d'un tronc agé du Cycas circinalis. Ann. Sci. nat. Bot. ser. 3. 5: 11-24, Jan 1846.

Note: French version of no. 92 (1844).

Rev.: Bot. Zeitung 6: 202. 10 Mar 1848.

102. [Manna,] Bot. Zeitung 4: 416. 12 Jun 1846.

103. Oratio de regno vegetabili in telluris superficie mutanda efficaci. Quam publice habuit die II. m. Martii MDCCCXLVI quum in Athenaeo illustri Amstelaedamensi medicinae et botanices professionem ordinariam auspicaretur. Amsterdam, Typographia civitatis publica, 1846. Qu. pp. 43.

Date: Mar-Jul 1843. It was not yet customary at that time to have the academic addresses printed on the day of the oration. Miquel sent copies to Kunze on 13 Jul 1846 (letter Kunze to M. 12 Aug 1846) and to Schlechtendal on 9 Jul 1846 (letter HAL).

104. Aanteekening omtrent eenen nieuwen Cycadeën-vorm in Amerika en derzelfs verhouding tot enige fossile [sic] typen uit deze plantengroep. Het Instituut 1846: 154-157. t. 1. 1846.

Date: probably Jul-Dec 1846 [article dated Jun 1846 on p. 157; probably part of fasc. 2].

105. Over eene tegennatuurlijke ontwikkeling van de bloemen eener Cissus, veroorzaakt door eene entophytische Puccinia. Het Instituut 1846(3): 320-327. 1846.

Date: Aug-Dec 1846 (on p. 274 a paper dated 8 Jul 1846). 
106. Annotationes in Piperaceas herbarii Arnottiani praesertim indicas a cel. Wight lectas. London Journ. Bot. 5: 548-559. 1846.

Date: Oct-Dec 1846 [p. 548 carries date 7 Sep 1846].

107. [Co-editor of ] Flore des serres et des jardins de l'Europe ou descriptions et figures des plantes les plus rares et les plus méritantes nouvellement introduites sur le continent ou en Angleterre, et soit inédites, soit extraites des meilleurs recueils de botanique et d'horticulture; ouvrage orné de vignettes représentant le port des plantes, et les sites de leurs contrées natales et contenant leur histoire, leur étymologie générique et spécifique, leur application d la médecine et l'économie domestique ou industrielle, leur culture raisonnée, etc., etc. Rédigé par Messieurs: [vol. 7] C. L. Blume, Ad. Brongniart, J. De Caisne, Alph. De Gandolle, F. E. L. Fischer, H. R. Goeppert, Louis van Houtte, Adr. de Jussieu, G. Miquel, J. E. Planchon, Achille Richard, Aug. de St.Hilaire, Scheidweiler, D. Spae, de Vriese, vols. 2-10, 1846-1855.

Note: Although Miquel's name figures as that of one of the editors ('rédigé par...") on the title-page of volumes $2-10$, he actually contributed very little to the journal (cf. no. 150, 1852). The actual editor was the publisher Louis Van Houtte, in collaboration with Ch. Lemaire.-Many plates in the Flore des Serres were copied from the Botanical Magazine.

Ref.: PR 10738.

108. Collectanea nova ad Cycadearum cognitionem. Linnaea 19(4): 411-430. tt. 1-7. 1847.

Date: prob. Apr 1847 (for dates Linnaea see Appendix I, p. 90).

Pars altera: see no. $123,1848$.

Rev.: Bot. Zeitung 5: 255. 14 Mai 1847.

109. Bestimmungen einiger von Hrn P. Clausen in Brasilien gesammelten Pflanzen. Linnaea 19(4): 431-446. 1847.

Date: prob. Apr 1847 (for dates Linnaea see Appendix I, p. 90).

Rev.: Bot. Zeitung 5: 355. 14 Mai 1847.

110. Mantissa piperacearum e speciminibus Musei vindobonensis, regii monacensis et martiani. Linnaea 20: 117-182. t. 1. 1847.

Dates: pp. 117-128 in Heft 1, Mai 1847

pp. 129-182 in Heft 2, Jun 1847

tab. I issued with Heft 3, Jul 1847

(For dates of Linnaea see Appendix I, p. 90).

Rev.: Bot. Zeitung 5: 837. 19 Nov 1847.

111. Illustrationes piperacearum. Nov. Act. Acad. Nat. Cur. 21 Suppl. 1. 1846. Qu., pp. 87, tt. xiii.

Date: Jul-Dec 1847. Although the title-page bears the date 1846 , the book was published only in the second half of 1847 . On $25 \mathrm{Jun} 1847$ it is stated in the Bot. Zeitung (5: 464) "Ein Supplementband zu Vol. 21 der Acta..., Miquel's Piperaceen enthaltend, ist bis auf einige Tafeln fertig".-Preface dated Mar 1844. 
Note: This "Supplementband" contained only the present publication. Reprints were issued with only the title-page to Miquel's article, with no additional imprint except "(Nova acta Acad. Caes. Leop. Carol. Nat. Cur. Vol. XXI. Suppl.)".

Plates: The excellent plates are uncoloured lithographs after drawings by Q.M.R. Ver Huell. Many copies lack one or more of the 92 plates.

Rev.: Bot. Zeitung 7: 654. 7 Sep 1849.

112. Over eenige nieuwe of zeldzame Cycadeën in den Hortus Botanicus te Amsterdam.

Eerste gedeelte. Tijdschr. wis- en natuurk. Wet. 1(1): 33-43. 1847.

Date: Jul-Dec 1847 (p. 62 article dated 15 Mai 1847; original cover part 1 dated 1847).

113. - Tweede gedeelte. Over de onlangs opnieuw ontdekte Cycas inermis, Lour. Tijdschr. wis- en natuurk. Wet. 1(2): 103-109. 1847.

Date: Sep 1847-Mai 1848 (original cover of part not seen, latest date in part 24 Jul 1847 on p. 102).

113a. -Derde gedeelte. Tijdschr. wis- en natuurk. Wet. 1(4): 197-208. 1848.

Date: Mai-Dec 1848 [last date in part 26 Apr 1848 on p. 253. Another two fascicles of the $T_{i j d s c h r i f t}$ were still published in 1848 after 1(4). Publication of 1(4) therefore probably med. 1848].

Rev.: Schlechtendal, Bot. Zeitung 7: 299-204. 16 Mar 1849.

114. Peperomiae species duas novas indicat. London fourn. Bot. 6 : 459-460 [in the second set of pages carrying these numbers]. 1847.

Date: Aug-Dec 1847 (p. 460 dated Jul 1847).

115. Prodromus monographiae Ficuum [published in parts in] London Fourn. Bot. 6: 514-588. (t. xx) 1847; 7: 64-78 (t. ii). 109-116 (t. iii), 221-236, 425-442, 451-471. 1848.

Dates: 6 : $514-588$ probably Nov-Dec $1847 ; 7: 64-78$ probably Jan 1848, later parts Feb-Dec 1848.

Note: On p. 471 it is stated that the series is "to be continued", but no continuation was ever published.

Rev.: Bot. Zeitung 6: 803-805. 17 Nov 1848.

116. Over de verwantschap der Polygaleën. Tijdschr. wis- en natuurk. Wet. 1(3): 134-154. 1848.

Date: Jan-Jun 1848 [part 1(3) was the first of four parts issued in the course of 1848. All articles in this part carry dates between Oct and Dec 1847].

Rev.: Bot. Zeitung 7: 202. 16 Mar 1849.

117. Revisio critica Casuarinarum. Nieuwe Verh. Eerste Klasse Kon. Ned. Inst. Wet. 13: 267-350. tt. i-xii. 1848. 
Date: Feb 1848. [The article was also published separately. It is not known whether the reprints preceded the publication of the volume of the Verhandelingen, or whether the volume of the Verhandelingen was published in parts. Miquel sent copies to Lindley and Kunze on $10 \mathrm{Feb} 1848$ (Letter to Lindley at $\mathrm{K}$, acknowledgement receipt by Kunze in letter of 3 Apr 1848, ULU). The copy for W. J. Hooker was forwarded on 30 Mar (letter at K); on $15 \mathrm{Apr}$ 1848 Schlechtendal owned a copy].

Rev.: Schlechtendal, Bot. Zeitung 6: 451-452. 16 Jun 1848.

Flora 31 : 472-479. 7 Aug 1848, 485-488. 14 Aug 1848.

118. Uittreksels uit botanische berigten over de flora van Suriname in brieven medegedeeld door den Heer Mr. H. C. Focke, te Paramaribo, correspondent van de Eerste Klasse des Instituuts (uit brieven dd. 27 Nov. en 9 Dec. 1847). Tijdschr. wis- en natuurk. Wet. 1(4): 209-212. 1848.

Date: Mai-Dec, but probably medio 1848 (see under no. 116).

119. Ueber einige neue oder seltsame Cycadeen in dem botanischen Garten zu Amsterdam. Neue allg. deutsche Garten- u. Blumenzeitung 4: 328-335. Jul 1848, 371-375. Aug 1848; 518-525. Nov 1848.

Note: Translation of nos. 112-1138.

120. Aeschynanthi speciem novam proponit..., Bot. Zeitung 6: 509-510. 14 Jul 1848.

121. Piperaceae Reinwardtianae. Linnaea 21(4): 480-486. 1848.

Date: Aug 1848 (on cover; cf. Appendix I, p. 90).

122. Voyriae species quasdam surinamenses recenset... Tijdschr. wis- en natuurk. Wet. 2(2): 122-125. 1848.

Date: Aug-Dec 1848, but probably rather late in the year. [Part 2(2) was the last of the four parts issued in 1848, the date on the cover was 1848, the last date in the part is 11 Jul 1848 on p. 164; Kunze acknowledges receipt on 4 Mar 1849 (letter ULU).]

Rev.: Schlechtendal, Bot. Zeitung 7: 235-236. 30 Mar. 1849.

123. Collectanea nova ad Cycadearum cognitionem. Pars altera. Germinatia. Linnaea 21 (5) : 561-568. t. vi. 1848.

Date: Oct 1848 (for dates Linnaea see Appendix I, p. 90).

Note: For pars prior see no. 108, 1847.

124. [Hortus Amstelodamensis of Afbeeldingen en beschrijvingen van merkwaardige gewassen uit den Hortus botanicus te Amsterdam. AmsterdamC. G. van der Post, Fol.]

This publication, announced in a separately printed prospectus and in the Botanische Zeitung 6:292 (7 Apr 1848) never appeared. It was planned to issue two parts of 6 plates plus accompanying text per year.

125. [Editor of] Tijdschrift voor de wis- en natuurkundige wetenschappen uitgegeven door de eerste klasse van het Koninklijke Nederlandsche Instituut van Wetenschappen, Letterkunde en Schoone Kunsten, onder redactie van F. A. W. Miquel, H. G. van der Boon Mesch, R. van Rees, W. Vrolik. Volumes 1-5, 1848-1852. 
126. Ficuum species nigritanae. London Journ. Bot. 7: 563-564. tt. $x i i-x v .1848$.

127. Epicrisis systematis cycadearum. Tijdschr. wis- en natuurk. Wet. 2(4) : 280-302. 1849.

Date: Feb-Jul 1849 [second part of Tijdschrift to be published in 1849; date on p. 27927 Dec 1848, review Bot. Zeitung 31 Aug].

Rev.: Bot. Zeitung 7: 640. 31 Aug 1849.

128. Plantae Kegelianae surinamenses. Linnaea 22(1): 71-80. 1849. Date: Mar 1849 (on cover, cf. Appendix I, p. 90).

129. Plantae Regnellianae [Myrtaceae, Melastomaceae, Oxalideae, Polygaleae, Malpighiaceae, Büttneriaceae, Sterculiaceae, Malvaceae, Violarieae, Saxifrageae, Ericaceae, Asclepiadeae, Apocyneae, Piperaceae]. Linnaea 22(5): 532-546. 550-556, 558, 567-569, 574. 1849.

Date: Sep 1849 (on cover, see Appendix I, p. 90).

130. ["Description of the species belonging to the old genus of Ficus" in W. J. Hooker,] Niger flora 520-552. 1849.

Date: Nov-Dec 1849. - The Niger flora was published as a whole in November or December 1849. The dedication is dated 1 Nov 1849, the copy presented to Bentham by W. J. Hooker (K) is enscribed " 1849 ". The book was announced as published in the Fourn. Bot. Kew Gard. Misc. (1:380) of December 1849.

Note: W. J. Hooker (on p. 520) adds the following note on Miquel's monograph (cf. no. 115) " ... Dr Miquel to whom we are indebted for an elaborate and careful monograph of this most difficult group. It is only to be regretted that he had not left so natural and readily recognized a genus entire, giving sectional names only to his otherwise excellent divisions ...". W. J. Hooker sent a copy to Miquel on 14 Jul 1850 (letter at K).

Rev.: Bot. Zeitung 8: 307. 12 Apr 1850.

131. Voorrede [tot A. Wiggers,] Handboek der pharmakognosie, naar de tweede Hoogduitsche uitgave voor $\mathcal{N}$ ederlanders bewerkt door D. J. Coster, M.S. met eene voorrede van F. A. W. Miquel, M.D. Hoogleraar in de Genees- en Plantenkunde te Amsterdam. Amsterdam, M. H. Binger, 1849. Oct., [viii] and 846 pp. Voorrede on pp. [v-vi], dated Sep 1849.

Date: Sep-Dec 1849 (cf. preface).

Note: D. J. Coster was one of Miquel's Amsterdam pupils. The translator added short notes of his own as well as references to Dutch botanical literature.

Ref.: MI 444.

132. Over de Afrikaansche Vijge-boomen. Verh. Eerste Klasse Kon. Ned. Inst. Wet. ser. 3. 1: 111-150. tt. $i-v .1849$.

Date: probably Nov-Dec 1849 [Title-page 1849. Kunze acknowledged receipt of a copy on $6 \mathrm{Feb} 1850$; date review Flora 21 Feb 1850; this volume of the Verhandelingen received at Regensburg in Jan 1850, fide Flora 33: 64; books received by Academy listed in volume until 31 Oct 1849 . It is not quite certain, however, whether the volume was published as a whole].

Rev.: Fürnrohr, Flora 33: 103-112. 21 Feb 1850. Schlechtendal, Bot. Zeitung 8: 549-552. 19 Jul 1850. 
133. Manipulus stirpium Blanchetiarum in Brasilia collectarum. Linnaea 22(7): 793-807. 1850.

Date: probably Mai 1850 (for dates Linnaea see Appendix I, p. 190).

134. Analecta botanica indica seu commentationes de variis stirpibus asiae australioris.

Pars I, Stirpes quaedam borneensis. Verh. Eerste Klasse Kon. Ned. Inst. Wet. ser. 3. 3: 1-30. tt. i-x. 1850 [published as a separate fascicle].

Date: Mai 1850 [Miquel sent a copy to W. J. Hooker on 30 Mai 1850 (letter at $\mathbf{K})$ ];

Pars altera, Thymelaearum, Palmarum, Pandanearum, Graminearum, Cycadearum et Filicum species selectae. Verh. Eerste Klasse Kon. Ned. Inst. Wet. ser. 3. 4: 13-56. $t$ t. $i$-vii. 1851 [published as a separate fascicle with the addition of loose-leaved preliminary matter, dated 31 Aug 1850 on p. ix].

Date: between $1 \mathrm{~J}$ an and $16 \mathrm{Feb} 1851$ [Miquel sent a copy to W. J. Hooker on 16 Feb 1851, (letter K), another was received by Kunze in Leipzig on 25 Mar 1851 (letter ULU); a copy was sent to Schlechtendal in February (letter HAL)].

Pars III vel posthuma. Novae vel rariores species dicotyledoneae. Verh. Eerste Klasse Kon. Ned. Inst. Wet. ser. 3. 5: 1-30. tt. i-iii. 1852 [published as a separate fascicle].

Date: between 13 and 19 Feb 1852 [Weekblad Boekhandel 2(8), 21 Feb 1854; a copy was sent to Schlechtendal on $16 \mathrm{Feb} 1852$ (letter ULU)].

Rev.: Fürnrohr, Flora 34: 94-95. 14 Feb 1851 (pars 1).

Ref.: MI 394, 395; PR 6271.

135. [Review of C. L. Blume,] Rumphia, ... tome IV. Alg. Konsten Letterbode 1850(1): 281-288. 3 Mai 1850.

136. [review of C. L. Blume,] Museum botanicum Lugdunobatavum, aflev. I-IX. Alg. Konst-en Letterbode 1850(1): 313-314. 17 Mai 1850.

137. [Letter to the editor on J. J. Alberda, de Blindgeborene in de maatschappij en Het blinde kind in] Alg. Konst- en Letterbode 1850(2): 289-297. 8 Nov 1850.

138. [review of G. J. Mulder,] Proeve eener algemeene physiologische scheikunde. Alg. Konst.- en Letterbode 1850(2): 415. 27 Dec 1850.

139. [review of] De plantenkunde, algemeen bevattelijk voorgesteld door Dr Moritz Seubert ... naar het Hoogduitsch door C. A. J. A. Oudemans. Alg. Konst- en Letterbode 1850. 2: 188-189. 20 Sep 1850 (part 1), 1851(1): 45-47. 17 Jan 1851 (parts 2, 3, 4). 
140. [review of] Natuurkundige Verhandelingen van de Hollandsche Maatschappij der Wetenschappen te Haarlem. Tweede verzameling, vol. 5(2) [C. C. Beinert, H. R. Göppert], vol. 6 [H. R. Göppert] [both palaeobotanical publications]. Alg. Konst- en Letterbode 1851(1): 61-63. 24 Jan 1851.

141. [review of] Handleiding der Algemeene Plantenkunde, ten gebruike bij het onderwijs aan 's Rijks Kweekschool voor Militaire Geneeskundigen, door J. van Rijn van Alkemade. Alg. Konst- en Letterbode 1851(1): 91-93. 7 Feb 1851.

142. [review of C. L. Blume,] Museum botanicum Lugduno-Batavum. Alg. Konst- en Letterbode 1851(1): 127, 129. 21 \& 28 Feb 1851.

143. Stirpes surinamenses selectae. Leiden, Arnz \& Soc., 1850. Qu., pp. viii, 234, tt. 65.-Published separately as well as in Natuurk. Verh. Holl. Maatsch. Wet. Haarlem ser. 2. 7: [i-viii), [1]-234. 1851.

Date: Mar 1851 [Flora 34: 190-192. 28 Mar 1851 "in dieser Woche herausgegeben"; copy sent to W. J. Hooker on 5 Mar 1851 (letter K). Kunze received a copy on 25 Mar 1851 (letter ULU)].

Note: Volume 7 of the Verhandelingen contained the Stirpes as the only paper; it contains a title-page of the Verhandelingen dated 1851 and the title-page of the Stirpes dated 1850 .

Plates: 65 uncoloured lithographs after drawings by Q.M.R. Ver Huell.

Rev.: J. K. Hasskarl, Flora 34: 190-192. 28 Mar 1851.

Ref.: NI 1391, PR 6270.

144. Plantae Junghuhnianae. Enumeratio plantarum, quas in insulis Fava et Sumatra, detexit Fr. Junghuhn. Leiden, A. W. Sythoff, 1851 [-1857]. Oct., 572 pp.

Dates:

$\begin{array}{ccll}\text { part } & \text { pages } & & \text { dates } \\ 1 & 1-106 & \text { Mar } & \mathbf{1 8 5 1} \\ 2 & 107-270 & \text { Aug } 1852 \\ 3 & 271-394 & \text { Aug } 1854 \\ 4 & 395-522 & \text { 1855 or } 1857 ? \\ 5 & 523-572 & 1857 & \end{array}$

Notes: The major part of the text is by Miquel, but a number of families are dealt with by other authors: G. Bentham, R. B. van den Bosch, A. J. de Bruyn, L. A. J. Burgersdijk, L. H. Buse, F. Dozy, J. K. Hasskarl, J. H. Molkenboer, C. Montagne, C. M. van der Sande Lacoste, A. Spring, and W. H. de Vriese.-Miquel, perhaps together with W. H. de Vriese, acted as general editor. The history of the publication of parts 4 and 5 is not yet quite clear. On 31 Jan 1857 [sic] Miquel and de Vriese presented parts 1-3 to the Royal Academy of Sciences. It is recorded in the Verslagen en Mededeelingen der Koninklijke Akademie van Wetenschappen, Afdeeling Natuurkunde (6: 53-58. 1857) that the "fourth and last part" had not yet appeared. The official registers of the Academy also record the receipt of parts 1-3 for January 1857. W. J. Hooker reviewed parts $1-4$ in his Journal of Botany and Kew Garden Miscellany for November 1857 (9: 352). For further details see v. Steenis (1947) and v. Steenis-Kruseman (1960).

Descriptive announcements, almost certainly by Miquel, in the Alg. Konst- en Letterbode fasc, $1-2$ in 1852(2): 122-123. 20 Aug 1822; fasc. 2 (again) 1853(2): 
267-268. 21 Oct 1853). A review by C. A. J. A. Oudemans of fasc. 3 was published in the volume for 1854: 273-274. 26 Aug 1854.

Ref.: PR 6272

Dunn, Journ. Bot. 51 : 358. 1913.

Wiltshear, Journ. Bot. 52: 44-45. 1914.

v. Steenis, Fl. males. Bull. 1: 50. 1947.

Marshall, Kew Bull. 1953: 279-280.

v. Steenis-Kruseman, Fl. males. ser. 1. 4: ccii. 1954.

v. Steenis-Kruseman, Fl. males. Bull. 3: 823. 1961.

145. [Review of C. A. J. A. Oudemans,] Systematisch overzicht der geneeskrachtige gewassen volgens de nieuwste bronnen opgemaakt. Alg. Konst- en Letterbode 1851(1): 189-190. 21 Mar 1851.

146. Over de rangschikking der fossiele Cycadeae. Tijdschr. wis- en natuurk. Wet. 4(3): 205-227. 1851.

Date: Jun-Dec 1851 (p. 264 article dated 25 Apr 1851).

147. De quibusdam plantis fossilibus. Tijdschr. wis- en natuurk. Wet. $4(4)$ : 265-269. 1851.

Date: Jul-Oct 1851 [p. 328 date paper 3 Jul 1851; 5(1) was published between 14 and 20 Nov 1851 (Weekblad Boekhandel $1(8) .22$ Nov 1851).

148. Cycadeae quaedam americanae, partim novae. Verh. Eerste Klasse Kon. Ned. Instituut Wet. ser. 3. 4: 181-188. tt. i-iv. 1851.

Date: 1851 -Reprinted with original pagination and blank cover.

1852

149. Chloranthaceae et Piperaceae, in C. F. P. von Martius, Flora brasiliensis 4(1): 1-76. tt. 1-24. 15 Aug 1852 [fasc. 11].

150. Sur une espèce nouvelle de Zamia des Indes occidentales, introduite dans l'établissement Van Houtte, à Gand. Flore des serres et des jardins de l'Europe (L. van Houtte et al.) 7: 141-142. 1851-1852.

Date: 1852 (a publication from 1852 is cited on p. 142).

151. Fungorum aliquot exoticorum recensio. Tijdschr. wis-en natuurk. Wet. 5: 188-198. tt. xi-xiii. 1852.

Date 1852. It is not certain that volume 5 consisted of the usual four parts; Miquel's article, however, is at any rate in the last part, published in 1852.

The papers in the volume which are dated carry dates between April and December 1851.

152. [Address to the extraordinary general Assembly of the Koninklijk Nederlandsche Instituut van Wetenschappen, Letterkunde en Schoone Kunsten, 15 Dec 1851]. Jaarboek van het Koninklijk Nederlandsch Instituut 1851: 125-130. 1852.

153. De voedselplanten van den mensch. Album der natuur 1852: 361-373. 
1853

154. Cycadis Rumphii stirps femina. Linnaea 25(5): 589-592. t. ii. 1853.

Date: Jun 1853 (date on cover, see Appendix I, p. 90).

155. Malvaceae. Exposuit F. A. Guil. Miquel. Martio 1853.-This pamphlet, with a separate pagination (23 pp.) but without any further title-page, is a reprint from no. 144, Plantae Junghuhnianae pp. 279-301, published Aug 1853.

156. Urticinae, in C. F. P. von Martius, Flora brasiliensis 4(1): 77-218. tt. 25-70. 1 Dec 1853 [fasc. 12].

Rev.: Fürnrohr, Flora 38: 354-357. 21 Jun 1855.

157. Mantissa Piperacearum, in C. F. P. von Martius, Flora brasiliensis 4(1): 219-222. 1 Dec 1853 [fasc. 12].

158. Species aliquot novas Valdivianas a Domino W. Lechler collectas. Linnaea 25(6): 650-654. 1853.

Date: Dec 1853 (date on cover, cf. Appendix I, p. 90).

159. De fossiele planten van het krijt in het hertogdom Limburg. Verhandelingen uitgegeven door de Commissie belast met het vervaardigen eener geologische beschrijuing en kaart van Nederland 1(2): 33-56 [1-24]. tt. 1-7. 1853.

Date: 1853, probably Dec ["am Ende des...Jahres", Bonplandia 2: 171. 1854, correspondence from Amsterdam; Ferd. Roemer acknowledged the receipt of a copy to Miquel on 17 Apr 1854 (letter ULU)].

Rev.: Alg. Konst-en Letterbode 67: 92-93. 24 Mar 1855 (vols. 1 \& 2).

160. De Truffels. Album der Natuur 1853: 187-190 [also reprinted cf. MI 391].

\section{4}

161. Artocarpeae, Piperaceae in Berthold Seemann, The botany of the Voyage of H.M.S. Herald, under the command of Captain Henry Kellett, R.N.N., C.B., during the years 1845-1851 London, Lovell Reeve, 18521857. Qu., pp. vi, 483, tt. 100. [Artocarpeae on] pp. 195-197, tt. 35-36, [Piperaceae on] pp. 198-200. tt. 37-42 [in 2. Flora of the Isthmus of Panama, pp. 57-254].

Date: Miquel's contributions are in parts $4(t t .37-40)$ and 5 (tt. 41-42, pp. 195-200) which were published in Feb and Jul 1854 respectively. Types: BM.

Plates: Uncoloured lithographs after drawings by W. Fitch and J. D. Hooker.

Rev.: [of part 5] Gard. Chron. 29 Jul 1854.

Journ. Bot. Kew Gard. Misc. 6: 319. 1854.

Amer. Fourn. Sci. 18: 429. Nov 1854.

Ref.: MI 422 (reprint), PR 8575.

Britten, Fourn. Bot. 1889: 102-105.

Sprague, Journ. Bot. 59: 22-24. 1921.

v. Steenis-Kruseman, Fl. males. Bull. 3: 824. 1961. 
162. Stirpium novarum sylloge. Linnaea 26(2) : 217-223. 1854.

Date: Apr 1854 (cover, cf. Appendix I, p. 90).

163. Excerpta observationum de Rafflesia Rochussenii femina editarum, cum annotatione epicritica. Linnaea 26(2): 224-234. 1854

Date: Apr 1854 (date cover; see Appendix I, p. 90).

Rev.: Bot. Zeitung 13: 847. 30 Nov 1855.

164. De ramificatione monstrosa in arbore Sumatrana observata. Linnaea 26(3) : 285-291. t. iii. 1854.

Date: Aug 1854 (cover, cf. Appendix I, p. 90).

Rev.: Bot. Zeitung 13: 869. Dec. 1855.

165. Monochlamydeen, in H. Zollinger, Systematisches Verzeichniss der im indischen Archipel in den Jahren 1842-1848 gesammelten sowie der aus Japan empfangenen Pflanzen. [Heft 2], pp. 80-119. 1854.

Note by Zollinger (p. 80) "Sämmtliche Monochamydeen sind bearbeitet von Herrn Dr Miquel... ausgenommen die Familien der Chenopodiaceen, Amarantaceen, Polygoneen, Nepentheen und Aristolochieen."

Date: Nov 1854-Jan 1855. [Heft 2 consists of pp. 81-160; p. 156 is dated 1 Nov 1854. On $3 \mathrm{Feb} 1855$ Zollinger writes to Miquel (ULU) to inform him that it is ready and that reprints have been made. The title-page for Heft 1 and 2 together carries the date 1854, which would point at publication in Nov-Dec 1854].

166. Naschrift [bij] G. A. Venema, De barnsteen in het oostelijk gedeelte der provincie Groningen. Verhandelingen uitgegeven door de commissie belast met het vervaardigen eener geologische beschrijving en kaart van Nederland 2: 139-156 [Naschrift 151-156] [1-18]. 1854. [Also published as a reprint, Haarlem 1854, Qu. 18 pp.].

\section{5}

167. Flora van Nederlandsch Indië. Amsterdam, G. C. van der Post, Utrecht, C. van der Post Jr., Leipzig bij Fried. Fleischer. 3 volumes 1855-1859. Oct.- -alternative title Flora Indiae batavae.

Dates: The following dates are those on which the publication of the various parts was announced in the Nieuwsblad voor den Boekhandel except for the dates marked with an asterisk which stem from other sources cited by v. Steenis (1934, 1947) and v. Steenis-Kruseman (1960).

$\begin{array}{ccccc}\text { Vol. } & \text { part } & \text { pages } & \text { plates } & \text { dates } \\ 11 & 1 & 1-160 & 1-2 & 2 \text { Aug } 1855 \\ & 2 & 161-336 & 3-4 & 6 \text { Sep 1855 } \\ & 3 & 337-512 & 5-7 & 20 \text { Dec } 1855 \text { [Oct } 1855^{*} \text { ] } \\ & 4 & 513-688 & 8-9 & \text { Apr } 1856 \\ & 5 & 689-864 & 10-11 & 10 \text { Jul } 1856 \\ & 6 & 865-1040 & 12-13 & 19 \text { Aug } 1858 \\ & & 1041-1116 & & \\ & & & \end{array}$




$\begin{array}{cc}\text { Vol. } & \text { part } \\ \mathbf{1}^{2} & 1 \\ & 2 \\ & 3 \\ & 4 \\ 2 & 1 \\ & 2 \\ & 3 \\ & 4 \\ & 5 \\ & 6 \\ & 6 \\ & 7\end{array}$

pages
$1-176$
$177-352$
$353-512$
$513-704$
$1-176$
$177-352$
$353-528$
$529-704$
$705-880$
$881-960$
$961-1103$, t.p.
contents, xi pp.
$1-176$
$177-352$
$353-528$
$529-773$

plates
$15-18$
$19-24$
$25-29$
30
$31-32$
$33-34$
35
36

3

1
2
3
4

table, 2 maps, $x$ pp.

$\begin{array}{cr}37 & 1 \text { Nov } 1855 \\ 3840 & 25 \text { Dec } 1856 \\ 41 & 26 \text { Nov } 1857 \\ 29 \text { Dec } 1859\end{array}$

23 Dec 1858

4 Aug 1859 [Mai 1859*]

6 Oct 1859

3 Nov 1859

4 Dec 1856

2 Jul 1857

20 Aug 1857

31 Dec 1857

8 Apr 1858

30 Sep 1858

4 Aug 1859

1 Nov 1855

26 Nov 1857

$41 \quad 29 \operatorname{Dec} 1859$

There is a slight descrepancy between the data on the contents of $1(2)$ parts 2 and 3 as given by the Nieuzesblad and by v. Steenis. The latter's findings have been followed.

Plates: The plates are uncoloured lithographs of drawings by Q.M.R. Ver Huell. The frontispiece to vol. 1 (Rumphius) is by C. C. A. Last.

Rev.: Many reviews and announcements were published in several journals. They are too numerous to be cited in detail. Most faithful in recording the publication was the Botanische Zeitung which carried reviews (in vols. 14-17) of nearly all fascicles from the hands of Schlechtendal, Oudemans and Knüttel. Other reviews appeared in Flora, the Algemeene Konst- en Letterbode (67: 265, by Oudemans), the Journal of Botany and Kew Garden Miscellany (by W. J. Hooker), Bonplandia (by B. Seemann), Tuinbouw-flora (2: 86-95; 3: $350-351$, by W. H. de Vriese).

Note: For contemporary comments see W. H. de Vriese, Voorstel omtrent de voortzetting van de uitgave der Flora Javae, Tuinbouw-flora 3: 357-364 (1856) and J. Palacky, Ubersicht der von Miquel in der Flora Indiae batavae bestimmten Cumingschen Philippinen-Pflanzen, Flora 43: 446-448 (28 Jul $1860)$.

Ref.: MI 387, 388, PR 6274.

Kuntze, Rev. Gen. Pl. 3(2): 159-160. 1898.

Nakai, Journ. Arnold Arb. 6: 211-213. 1925.

v. Steenis, Bull. Fard. Bot. Buitenzorg ser. 3. $13: 284-285.1934$, Fl. males. Bull. 1: 50.1947.

Furtado, Chron. bot. 5: 437-438. 1939.

v. Steenis-Kruseman, Fl. males. ser. 1. 4 : ccii. 1954, Fl. males. Bull. 3: 739-740. 1960 .

168. Beschouwingen over de delfstoffen en de geschiedenis der aarde. Volume 5 of J. A. Uilkens. De volmaaktheden van den Schepper in zijne schepselen beschouwd, ter verheerlijking van God en tot bevordering van nuttige natuurkennis. Herzien en op de tegenwoordige hoogte der wetenschap gebracht. Leeuwarden, G. T. N. Suringar. 1855. Oct., pp. viii, $479, t$. 18.

Date: published in seven parts in the course of 1855. The Nieuwsblad voor den boekhandel announces the parts on 12 Apr (2), 17 Mai (3), 9 Aug (4), 13 Sep (5), 11 Oct (6) and 1 Nov (7).

169. Voorlopig berigt over eene nieuwe Wolffia. Ned. Kruidk. Arch. 3: 425-429. 1855, Natuurk. Tijdschr. Ned. Indië 10: 399-402. 1856.

Date: 1855 (in Ned. Kruidk. Arch.; article dated 6 Jan 1855). 
170. Ebenaceae, in C. F. P. von Martius, Flora brasiliensis 7: 1-10. tt. 1-3. 15 Mar 1856 [fasc. 17].

171. Symplocaceae, in C. F. P. von Martius, Flora brasiliensis 7: 21-36. tt. 8-14. 15 Mar 1856 [fasc. 17].

172. Primulaceae et Myrsinaceae, in C. F. P. von Martius, Flora brasiliensis 10: 257-324. tt. 23-59. 15 Mar 1856 [fasc. 16].

173. Araliacearum indicarum genera et species aliquod novae. Bonplandia 4: 137-139. 1 Mai 1856.

174. Aroïdeae novae javanicae. Bot. Zeitung 14: 561-565. 15 Aug 1856.

175. Stirpes novo-hollandas a Ferd. Müllero collectas. Ned. kruidk. Arch. 4(2): 97-150. 1856.

Date: 1856 (on cover, fide v. Steenis-Kruseman, $F l$. males. ser. 1 4(5) : cciii. 1954). Reprints were issued s.l.n.d. fide MI 428.

\section{7}

176. [with J. C. Groenewegen,] Catalogus horti botanici amstelodamensis. Amsterdam, M. Westerman \& Zoon, 1857. Oct., pp. 357.

Date: Jan 1857 [acquired by Royal Academy of Sciences in Jan, fide Versl. Med. Kon. Akad. Wet. afd. Natuurk. 6: 52-53 [report Miquel], 61 (accessions register); Miquel sent a copy to Schlechtendal on $18 \mathrm{Feb} 1857$ (letter HAL)]. Ref.: MI 433, PR 6276.

177. Rhodoleiae (Champ.) generis hactenus dubii characterem, adjectâ specie sumatranâ. Versl. Med. Kon. Akad. Wet. afd. Natuurk. 6(1): 122-128. 1857.

Date: Apr-Mai 1857 [on p. 128 an article dated Mar 1857; reviewed, see below, $13 \mathrm{Jun}]$.

Rev. Alg. Konst- en Letterbode 69: 190. 13 Jun 1857.

178. Nova genera Apocynearum indicarum. Versl. Med. Kon. Ned. Akad. Wet. afd. Natuurk. 6(2): 191-194. 1857.

Date: Apr-Jul 1857 [on p. 195 a report dated 28 Mar; reviewed, see below, on 1 Aug].

Rev.: Alg. Konst-en Letterbode 69: 246. 1 Aug 1857.

Ref.: MI 386 (reprint).

179. Araliaceae [and various other families in W. H. de Vriese, ] Plantae Indiae batavae orientalis fasc. 2, Leiden, E. J. Brill, 1857. Qu.

Date and contents: Miquel's contributions are all in fascicle 2, pp. 81-160, published 3 Oct 1857: 
Araliaceae, pp. 81-92

Compositae, pp. 127-138

Cyperaceae, pp. 139-143

Orontiaceae, pp. 148-151

Aroideae, pp. 151-153

Combretaceae, pp. 153-154

The work was to have been published in 10 parts of 80 pages and four plates each, but nothing was published beyond fascicle 2 .

Ref.: NI 2087, PR 9876.

H. C. D. de Wit, Fl. males. Bull. 1 : 167-168. 1950.

v. Steenis-Kruseman, Fl. males. ser. 1. 4: ccxvi. 1954.

180. Cactearum species novae, e collectione domini de Jonge ab Ellemeet in villâ Overduin Zeelandiae. Ned. kruidk. Arch. 4(3):336338. 1858.

Date: 1858 (on original cover, fide v. Steenis-Kruseman, Fl. males. ser. 1. 4: cciii. 1954).-Reprints were issued fide MI 385.

Reprint of diagnoses: Journ. Bot. néerl. 1(1): 77-78. 1861.

181. Leerboek der artsenij-gewassen. Nieuwe uitgave in verband met de Nederlandsche apotheek. Utrecht, C. van der Post Jr., Amsterdam, G. G. van der Post, 1859. Oct. xvi [berigt, voorrede], lx [inleiding, systematisch overzigt ], $406 \mathrm{pp}$.-Berigt dated Jul 1859, on p. iv.

Note: A re-issue of the sheets of the 1838 edition (see no. 44) with the exception of pages i-iv containing a new title-page and the "Berigt" and of the pages xlv-lx, containing the "Systematisch overzigt der volgens de Pharmacopoea neerlandica officinele gewassen".

Date: 11 Aug 1859 (announced as available in Nieuwsblad voor den Boekhandel 26: 135).

182. Inwijdingsrede over het tegenwoordig standpunt der plantenkunde, en haar verband met andere wetenschappen, uitgesproken ter aanvaarding van het hoogleeraarsambt in de wis- en natuurkundige faculteit der hoogeschool te Utrecht, den 28 September 1859. Utrecht, C. van der Post Jr., Amsterdam, C. G. van der Post, 1859. Oct. pp. 37.-Also published in Annales Academici 1859-1860: 235-257: 1862 (Qu.).

Date: 3 Nov 1859 (Octavo edition announced as available by Nieuwsblad voor den boekhandel 26: 198. 3 Nov 1859. It was not customary yet to have the address printed on the day of its delivery. The quarto edition, of which reprints were made, was not published until 1862).

183. Nouvelle espèce de Rhodoleia, découverte par M. J. E. Teysmann dans l'île de Sumatra. Ann. Hortic. Bot., Flore des Jardins Bays Bas 2: 115-119. 1859.

184. Nouveau genres indiens de la famille des Apocynées. Ann. Hortic. Bot., Flore des Fardins Pays Bas 2: 142-144. 1859. 
185. Flora van Nederlandsch Indië. Eerste Bijvoegsel. Sumatra, zijne plantenwereld en hare voortbrengselen. Met platen. Amsterdam, C. G. van der Post, Utrecht, C. van der Post Jr., Leipzig bij Fried. Fleischer. 1860. Oct., pp. xxiv, 656, tt. 4.-Alternative title-page: Flora Indiae batavae. Supplementum primum. Prodromus florae Sumatranae. Accedunt Tabulae IV.-Another issue, differing only in having one title-page with the following text: Sumatra, zijne Plantenwereld en hare voortbrengselen. Met vier platen. Amsterdam, C. G. van der Post, Utrecht, C. van der Post Jr. 1862._-German translation see no. 2041862.

Date: published in three parts, as follows

$\begin{array}{cccc}\text { part } & \text { pages } & \text { plates } & \text { dates } \\ 1 & \text { i-xx, 1-160 } & 1,2 & \text { Dec } 1860 \\ 2 & 161-336 & 3 & \text { Jun 1861 } \\ 3 & \text { xxi-xxiv, 337-656 } & 4 & \text { Dec 1861 }\end{array}$

From a letter by Miquel to W. J. Hooker (at K) it may be deduced that publication of part 1 took place very late in Dec 1860: "le premier [supplément] qui va paraitre". The preface is dated (p. xvi) Dec 1860. The Journ. Bot. neerl. of Jan 1862 (1:199) states "pars 1 1860", "pars 2 1861". In the absence of proof to the contrary, we must assume that publication of part 1 actually took place in 1860 as indicated on its original cover. On 30 Aug 1861, Miquel writes to W. J. Hooker (letter at K) "le [supplément premier] est déjà publie". Part 1 is announced as "recently published" in the Nieuwes. blad voor den Boekhandel of 3 Jan 1861, part 2 on 27 Jun, and part 3 on 19 Dec 1861. Miquel's statement in the fourn. Bot. néerl. (1: 199) that the third part "paraîtra dans le courant de cette année" must still refer to the year 1861 .

Plates: The four plates are uncoloured lithographs after drawings by Q.M.R. Ver Huell

Ref.: PR 6275.

v. Steenis, Fl. males. Bull. 2: 363. 1953.

v. Steenis-Kruseman, Fl. males. ser. 1-4: ccii. 1954.

186. Prodromus systematis Cycadearum. In honorem festi diei $x v \mathrm{kal} . \mathrm{m}$. julii mdccclxi, quo academia rheno-trajectina exacta xlo lustra celebrat. Utrecht, G. v. d. Post Jr, Amsterdam, G. G. v. d.Post, 1861. Qu. pp. 36.

Date: early Jul 1861 (Nieuwsblad Boekhandel $4 \mathrm{Jul}$ ), therefore available shortly before 15 Jul 1861, the 225th universary of the University of Utrecht.

Rev.: Schlechtendal, Bot. Zeitung 20:30. 24 Jan 1862.

[extract], Journ. Bot. néerl. 1(2): 192. Oct 1861, 193-198. Jan 1862.

187. Journal de botanique néerlandaise rédigé par F. A. W. Miquel, Professeur de botanique à l'Université d'Utrecht. Tome Premier. Amsterdam, G. G. van der Post, Utrecht, G. van der Post Jr., Leipzig: Carl Fr. Fleischer, Grimmaische Strasse, Paris: Leiber, Rue de Seine 13, Londres: Williams \& Norgate, 14. Henrietta Street, CoventGarden. 1861. Oct., pp. 384, $t$. . iii.

Dates: Only this first volume was published, in four instalments, as follows; 
F. A. W. MIQUEL, NETHERLANDS BOTANIST

$\begin{array}{cccc}\text { fasc. } & \text { pages } & \text { plates } & \text { dates } \\ 1 & 1-96 & i & 1-8 \text { Aug } 1861 \\ 2 & 97-192 & i i & \text { Oct } 1861 \\ 3 & 193-288 & i i i & \text { Jan } 1862 \\ 4 & 289-384 & & \text { ?Mai } 1862\end{array}$

Fasc. 1 was published on (or shortly before) 1 Aug 1861 fide Bot. Zeitung 19: 248. 23 Aug 1861 and Bonplandia 9: 274. $15 \mathrm{Sep} 1861$. It was announced as available by the Nieuzesblad voor den Boekhandel of 8 Aug 1861 and received by the Royal Academy of Sciences in the period Jul-Sep.-Fasc. 2 was received by the Academy in Oct 1861, fasc. 3 in Jan 1862 (published accessions records).

Plates: the three plates are uncoloured unsigned lithographs.

Ref.: MI 439, PR 6277.

188. Revue des Palmiers de l'île de Sumatra. Fourn. Bot. néerl. 1(1): 1-29. 1861 [1 Aug].

189. Elodea canadensis Rich. acclimatée dans les eaux d'Utrecht. Fourn. Bot. néerl. 1(1): 29-32. 1861 [1 Aug].

190. Plantes nouvelles cultivées dans le jardin botanique de l'Université d'Utrecht. Fourn. Bot. néerl. 1(1): 33-36. 1861 [1 Aug].

191. Remarques sur la flore du sud de la Chine. Fourn. Bot. néerl. 1(1): 84-96, 1(2): 97-129. 1861.

Dates: 1(1) Aug 1861, 1(2): Oct 1861 (cf. no. 187).

Commentary: E. D. Merrill, On Miquel's Kwangtung species as based on Krone's collection. Sunyatsenia 1: 1-48. tt. 1-20. 1930 (contains reductions of most of the species from Miquel's article, with illustrations of the types; cf. Merrill \& Walker, Bibl. 317).

192. Bourgeons développés sur les racines des fougères. Fourn. Bot. néerl. 1(2): 134-135. 1861 [Oct].

193. Température élevée du spadice d'un Philodendron selloum C. Koch, dans le jardin de l'Université d'Utrecht. Fourn. Bot. néerl. $1(2): 144-146.1861$ [Oct].

194. Note sur quelques espèces de Cinchona. Journ. Bot. néerl. 1(2): 139-143. 1861 [Oct].

195. Macrocystis pyrifera, gevonden op $46^{\circ} 23^{\prime} \mathrm{Z}$. Br. en $55^{\circ} 50^{\prime} \mathrm{OL}$. door den Heer J. Kruisinga, le stuurman aan boord van het Nederl. schip Hebé, in K. F. R. Andrau [ed.], Onderzoekingen met den zeethermometer als uitkomsten van wetenschap en ervaring, aangaande de winden en zeestromingen in sommige gedeelten van den oceaan uitgegeven door het Koninklijk Nederlandsch Meteorologisch Instituut te Utrecht in 1861. [Kemink \& Zoon, Utrecht 1861], pp. 169-171.

196. Verslag van de Heeren P. Harting, F. A. W. Miquel, en J. van der Hoeven over een in hunne handen gesteld, uit de zee opgehaald organisch voorwerp, over gronden door diepzeeloodingen in de Banda-zee opgebracht en over passaatstof. Versl. Med. Kon. Akad. Wet. afd. Natuurk. 11: 286-299. 1861. 
197. Note sur les Figuiers de la Nouvelle-Hollande. Fourn. Bot. néerl. I(3): 230-249. 1862 [Jan].

198. [review of G. A. J. A. Oudemans,] Ueber den Sitz der Oberhaut bei den Luftwurzeln der Orchideen. Foum. Bot. néerl. 1(3): 249-253. 1862 [Jan].

199. Remarques sur quelques espèces de Nepenthes. Fourn. Bot. néerl. 1(3): 272-280. tt. i-ii. 1862 [Jan].

200. [review of R. B. van den Bosch,] Hymenophyllaceae javanicae. Fourn. Bot. néerl. 1(3): 288, 1(4): 289-291. 1862 .

Date: p. 288 Jan 1862, pp. 289-291 probably around Mai 1862 (cf. no. 187).

201. Remarques sur le genre Nania. Journ. Bot. Néerl. 1(4): 292-297. t. iii. 1862 [?Mai].

202. Ueber Kaju Garu, ein wohlriechendes Holz in Indien, von Teysmann und Binnendijk, Vorstehern des botanischen Gartens in Buitenzorg in Java, mitgetheilt von Prof. Miquel. Bot. Zeitung 20: 265-266. 15 Aug 1862.

203. Over de geografische verspreiding der Ficeae, met een nader onderzoek omtrent de soorten welke in Amerika, noordelijk van de landengte van Panama, voorkomen. Versl. Med. Kon. Akad. Wet. afd. Natuurk. 13: 382-415. 1862.

Date: Published after $29^{\prime}$ Mar 1862, date of acceptance by Academy, see p. 416 and before 12 Dec 1863 date of review of article on p. 362-376 in Flora.Reprints were prepared, cf. MI 381.

204. Sumatra, seine Pflanzenwelt und deren Erzeugnisse. Mit vier Tafeln. Deutsche Ausgabe. Amsterdam C. G. van der Post, Utrecht G. van der Post Jr., Leipzig, Fried. Fleischer. 1862. Oct., pp. xxiv, 656, tt. iv.

Date: A note in Bonplandia dated 19 Nov 1862 (10:355) states that at that moment only part 1 had appeared.

Ref.: PR 6279.

\section{3}

205. Sapoteae, in C. F. P. von Martius, Flora brasiliensis 7: 36-108. tt. 15-47. 15 Jan. 1863 [fasc. 32]-partly in collaboration with C. F. P. von Martius and A. W. Eichler.

206. Over de Cycadeën in Nieuw-Holland. Versl. Med. Kon. Akad. Wet. afd. Natuurk. 15: 362-376. 1863.

Date: Apr-Nov 1863 [article accepted for publication 28 Mar 1863 (cf. p. 357); 12 Dec 1863 reviewed in Flora]-Reprints issued (cf. MI 378).

Rev.: Flora 46: 536-539. 12 Dec 1863.

Gartenflora [Regel] 1864: 28. 
207. Annales Musei botanici Lugduno-Batavi. Amsterdam, C. G. van der Post, Utrecht, C. van der Post, Jr. 4 volumes 1863-1869. Fol.

Publ.: The following analysis of the contents of the fascicles is based on a copy in the original wrappers at the Botanical Museum, Utrecht. The announcements of the parts in the Nieuwsblad voor den Boekhandel are alas not complete. The full dates [day, month, year] given below are those of the announcements. For the parts not mentioned in the Nieuwsblad some further indication of the dates of publication is found in the dates at which the complementary copies were mailed from Leiden. The government put a hundred copies at the disposal of the Rijksherbarium and Miquel for free distribution among collaborators and major taxonomic centres abroad. These copies, however, were not mailed in single fascicles, but in consignments of, mostly, 5 fascicles. The signed receipts of these consignments are in the archives of the Rijksherbarium. They provide a last date for the last fascicle included in the consignments. These dates are the ones given below with the sole indication of month and year [e.g. 2(5): Jan 1866]. All other dates, in brackets, are obvious inferences from the covers and from the dates of earlier and later parts.

\begin{tabular}{|c|c|c|c|c|c|c|}
\hline Tome & fasc. & folii & pages & tab. & $\begin{array}{l}\text { dates } \\
\text { on } \\
\text { covers }\end{array}$ & $\begin{array}{l}\text { further } \\
\text { dates }\end{array}$ \\
\hline \multirow[t]{2}{*}{1} & $\begin{array}{r}1 \\
2 \\
3 \\
4 \\
5 \\
6 \\
7 \\
8 \\
9 \\
10\end{array}$ & $\begin{array}{c}1-8 \\
9-16 \\
17-24 \\
25-32 \\
33-40 \\
41-48 \\
49-56 \\
57-64 \\
65-72 \\
73-80\end{array}$ & $\begin{array}{c}1-32 \\
33-64 \\
65-96 \\
97-128 \\
129-160 \\
161-192 \\
193-224 \\
225-256 \\
257-288 \\
289-320 \\
\text { i-viii }\end{array}$ & $\begin{array}{r}1 \\
2 \\
3 \\
4 \\
5 \\
6 \\
7 \\
8 \\
9 \\
10\end{array}$ & $\begin{array}{l}1863 \\
1863 \\
1863 \\
1863 \\
1863 \\
1864 \\
1864 \\
1864 \\
1864 \\
1865\end{array}$ & $\begin{array}{r}2 \text { Jul } 1863 \\
6 \text { Aug } 1863 \\
24 \text { Sep } 1863 \\
5 \text { Nov } 1863 \\
17 \text { Dec } 1863 \\
11 \text { Feb } 1864 \\
19 \text { Mai } 1864 \\
23 \text { Jun } 1864 \\
20 \text { Oct } 1864 \\
1 \text { Dec } 1864\end{array}$ \\
\hline & Ind. & $81-83$ & $321-331$ & - & 1865 & 23 Mar 1865 \\
\hline \multirow[t]{2}{*}{2} & $\begin{array}{l}1 \\
2 \\
3 \\
4 \\
5 \\
6 \\
7 \\
8 \\
9\end{array}$ & $\begin{array}{c}1-5 \\
6-13 \\
14-21 \\
22-29 \\
30-37 \\
38-45 \\
46-53 \\
54-61 \\
62-69\end{array}$ & $\begin{array}{c}1-20 \\
21-52 \\
53-84 \\
85-116 \\
117-148 \\
149-180 \\
181-212 \\
213-244 \\
245-276\end{array}$ & $\begin{array}{c}1 \\
2 \\
3 \\
4 \\
- \\
5,6 \\
7 \\
8 \\
10\end{array}$ & $\begin{array}{l}1865 \\
1865 \\
1865 \\
1865 \\
1865 \\
1866 \\
1866 \\
1866 \\
1866\end{array}$ & $\begin{array}{l}23 \text { Mar } 1865 \\
\text { [Apr-Dec 1865] } \\
\text { [Apr-Dec 1865] } \\
\text { [Apr-Dec 1865] } \\
\text { Jan 1866 } \\
\text { Jan 1866 } \\
\text { [Feb-Nov 1866] } \\
\text { [Feb-Nov 1866] } \\
\text { [Feb-Nov 1866] }\end{array}$ \\
\hline & 10 & $70-79$ & $\underset{\text { i-vi }}{277-313}$ & {$\left[\begin{array}{c}{[\mathrm{Sic}]} \\
9\end{array}\right.$} & 1866 & Dec 1866 \\
\hline 3 & $\begin{array}{r}1 \\
2 \\
3 \\
4 \\
5 \\
6 \\
7 \\
8 \\
9 \\
10\end{array}$ & $\begin{array}{c}1-8 \\
9-16 \\
17-24 \\
25-32 \\
33-40 \\
41-48 \\
49-56 \\
57-64 \\
65-72 \\
73-79\end{array}$ & $\begin{array}{c}1-32 \\
33-64 \\
65-96 \\
97-128 \\
129-160 \\
161-192 \\
193-224 \\
225-256 \\
257-288 \\
289-315 \\
\text { i-vi }\end{array}$ & $\begin{array}{c}1,2 \\
\overline{3} \\
4 \\
5 \\
6 \\
7 \\
8 \\
9 \\
10\end{array}$ & $\begin{array}{l}1867 \\
1867 \\
1867 \\
1867 \\
1867 \\
1867 \\
1867 \\
1867 \\
1867 \\
1867\end{array}$ & $\begin{array}{c}\text { [Jan-Jun 1867] } \\
\text { [Jan-Jun 1867] } \\
\text { [Jan-Jun 1867] } \\
\text { [Jan-Jun 1867] } \\
\text { Jul 1867 } \\
\text { [Aug-Oct 1867] } \\
\text { 21 Nov 1867 } \\
\text { [Dec'67-Jul'68] } \\
\text { [Dec'67-Jul '68] } \\
\text { Aug 1868 }\end{array}$ \\
\hline
\end{tabular}




\begin{tabular}{|c|c|c|c|c|c|c|}
\hline Tome & fasc. & folii & pages & tab. & $\begin{array}{l}\text { dates } \\
\text { on } \\
\text { covers }\end{array}$ & $\begin{array}{l}\text { further } \\
\text { dates }\end{array}$ \\
\hline \multirow[t]{2}{*}{4} & $\begin{array}{l}1 \\
2 \\
3 \\
4 \\
5 \\
6 \\
6 \\
7 \\
8 \\
9\end{array}$ & $\begin{array}{c}1-8 \\
9-16 \\
17-24 \\
25-32 \\
33-40 \\
41-48 \\
49-56 \\
57-64 \\
65-72\end{array}$ & $\begin{array}{c}1-32 \\
33-64 \\
65-96 \\
97-128 \\
129-160 \\
161-192 \\
193-224 \\
225-256 \\
257-288\end{array}$ & $\begin{array}{c}1 \\
2 \\
3 \\
4 \\
5 \\
6 \\
7 \\
8,9 \\
-\end{array}$ & $\begin{array}{l}1868 \\
1868 \\
1868 \\
1869 \\
1869 \\
1869 \\
1869 \\
1869 \\
1869\end{array}$ & $\begin{array}{c}\text { [Sep-Dec } 1868] \\
\text { [Sep-Dec } 1868] \\
\text { [Sep-Dec } 1868] \\
21 \text { Feb } 1869 \\
28 \text { Mar } 1869 \\
23 \text { Mai } 1869 \\
8 \text { Jul } 1869 \\
\text { 24 Oct } 1869 \\
\text { [Nov '69-Feb }\end{array}$ \\
\hline & 10 & $73-80$ & $\underset{i-v i}{289-319}$ & 10 & 1869 & [Mar 1870] \\
\hline
\end{tabular}

Rev.: Many reviews were published, e.g. in Flora, Bot. Zeitung, Amer. Joum. Sci. Arts, Jaarb. Kon. Ned. Maatsch. Tuinbouw.

Plates: The plates are coloured and uncoloured lithographs, often unsigned, but otherwise by various artists.

Note: The loose-leaved Utrecht copy in the original wrappers was presented by Mrs Miquel to Miquel's student J. C. Costerus on 27 Jan 1871.

Ref.: MI 364, 365, PR 6281.

Nakai, Journ. Arnold Arb. 6: 211-213. 1925, Bot. Mag. Tokyo 40: 363-365. 1926.

Beumée, Fl. males. Bull. 1 : 137. 1949.

v. Steenis-Kruseman, $F l$. males. ser. 1. 4: ccii. 1954.

208. Araliaceae novae, adjecta aliarum specierum praesertim indicarum revisione. Ann. Mus. bot. Lugd.-Bat. 1(1): 1-27. 1863 [Jul] [cf. also pp. 219-220].

209. Ericaceae japonicae. Ann. Mus. bot. Lugd.-Bat. 1(1): 28-32. t. 1, 1(2): 33-35. 1863 [Aug].

210. Ericaceae archipelagi indici. Ann. Mus. bot. Lugd.-Bat. 1(2): 36-45. t.2. 1863 [Aug].

211. Ampelideae novae, adjecta specierum praesertim indicarum et japonicarum epicrisi. Ann. Mus. bot. Lugd.-Bat. 1(3): 72-96. 1863 [Sep], 1(4): 97-101. 1863 [Nov].

212. Ueber eine neue Cycas aus Siam. Bot. Zeitung 30 Oct 1863.

213. Adnotationes de cupuliferis. Ann. Mus, bot. Lugd.-Bat. 1(4): 102-121. 1863 [Nov].

214. Thymelaeacearum genera nova e tribu Gyrinopearum. Ann. Mus. bot. Lugd.-Bat. 1(5): 132-133. 1863 [Dec].

215. Piperaceae. Ann. Mus. bot. Lugd.-Bat. 1(5): 134-141. 1863 [Dec]. 
216. Choix de plantes rares ou nouvelles cultivées et dessinées dans le jardin botanique de Buitenzorg. Publié avec un texte explicatif par F. A. W. Miquel, Professeur de Botanique à l'Université d'Utrecht. 's-Gravenhage, G. W. Mieling, 1863. Fol. 26 coloured lithographed plates accompanied by [in all] 30 numbered pages of text.

Date: Published in 13 parts of 2 plates each in 1863 and 1864. The set was probably completed by 11 Mar 1864 on which day the Ministry of colonial affairs presented a copy to the Rijksherbarium (Archives L, 1864, Aaz no. 25). It is not at all certain that all parts were issued separately. Part 1, with 2 plates only, was reviewed by Rauwenhoff, but the review of the complete work in Flora does not mention parts.

Note: Miquel published the book by order of the government (Ministry of colonial affairs).

Plates: 26 coloured lithographed plates of which nos $\mathrm{v}$ and $\mathrm{ix}$ are signed $\mathrm{Th}$. Rocke, the numbers iv, viii, xviii, xx J. E. L. Ljung.

Rev.: Rauwenhoff, Jaarb. Kon. Ned. Maatsch. Tuinbouw 1864: 121.

Flora 47: 397-398. 26 Jul 1864.

217. Verslag over den staat van het Rijksherbarium en de aldaar verrigte werkzaamheden gedurende het jaar 1862. s.l.n.d. [1863]. Oct. pp. 11.

Note: reprinted (25 copies) with separate pagination from the Staatscourant. Rev.: Schlechtendal, Bot. Zeitung 23: 234-235. 21 Jul 1865.

\section{4}

218. Animadversiones in nonnullas Bignoniaceas. Ann. Mus. bot. Lugd.-Bat. 1(7): 197-202. 1864 [Mai].

219. Poikilospermum Zippel., genus novum Urticacearum. Ann. Mus. bot. Lugd.-Bat. 1(7) : 203. 1864 [Mai].

220. Heliciae species amboinenses. Ann. Mus. bot. Lugd.-Bat. 1(7): 204. 1864 [Mai].

221. Myristiceae a Teysmanno et de Vriese collectae. Ann. Mus. bot. Lugd.-Bat. 1(7): 205-207. 1864 [Mai].

222. Observationes de Clusiaceis. Ann. Mus. bot. Lugd.-Bat. 1(7): 208-209. 1864 [Mai].

223. Scaevolae species Moluccanae. Ann. Mus. bot. Lugd.-Bat. 1(7): 210. 1864 [Mai].

224. Aurantiaceae novae. Ann. Mus. bot. Lugd.-Bat. 1(7): 211. 1864 [Mai].

225. Pygei species novae. Ann. Mus, bot. Lugd.-Bat. 1(7): 212. 1864 [Mai].

226. Dipterocarpaea novae vel minus cognitae. Ann. Mus. bot. Lugd.-Bat. 1(7): 213-215. 1864 [Mai]. 
227. Melastomaceae a Teysmanno et de Vriese in Celebes et insulis Moluccis collectae. Ann. Mus. bot. Lugd.-Bat. 1(7): 216-217. 1864 [Mai].

228. Antidesmeae novae. Ann. Mus. bot. Lugd.-Bat. 1(7): 218.1864 [Mai].

229. Mantissa Araliacearum, Ericacearum, Cupuliferarum et Aracearum. Ann. Mus. bot. Lugd.-Bat. 1(7): 219-221. 1864 [Mai].

230. Cinnamomi generis revisio. Ann. Mus. bot. Lugd.-Bat. 1(8): 254-256. 1864 [Jun], 1(9): 257-270. 1864 [Oct], 1(10): 317. 1864 [Dec].

Note: For competition with Meissner's treatment in de Candolle's Prodromus see letter by Meissner to Miquel of $16 \mathrm{Jul} 1864$. Meissner has priority.

231. Xanthophylli species. Ann. Mus. bot. Lugd.-Bat. 1(9) : 271-277. 1864 [Oct], 1(10): 317-318. 1864 [Dec].

232. Wormia subsessilis. Ann. Mus. bot. Lugd.-Bat. 1(10): 315.1864 [Dec].

233. De Orchipeda. Ann. Mus. bot. Lugd.-Bat 1(10): 316-317. t.x. $1864[\mathrm{Dec}]$.

234. Calpicarpum albiflorum. Teysm. et Binnend. Jaarb. Kon. Ned. Maatsch. Tuinbouw 29-32. t. [i]. 1864.

\section{5}

235. Synopsis specierum Casuarinae. Flora 48: 17-24. 25 Jan 1865, 33-39. 4 Feb 1865.

236. Prolusio florae japonicae. Amsterdam, C. G. van der Post, Utrecht, C. van der Post Jr., 1866-1867. Fol., pp. viii, 392, tt. 2.

Dates: The greater part of the book is a reprint from the Ann. Mus. bot. Lugd.-Bat.

\begin{tabular}{cccccc} 
pages book & $\begin{array}{c}\text { Annales } \\
\text { vol./pars }\end{array}$ & Annales pp. & tt. & dates Annales \\
$1-16$ & $2(3)$ & $69-84$ & - & Apr-Dec 1865 \\
$17-49$ & $2(4)$ & $85-116$ & - & Apr-Dec 1865 \\
$49-80$ & $2(5)$ & $117-148$ & - & \multicolumn{2}{c}{ Jan 1866 } \\
$81-112$ & $2(6)$ & $149-180$ & - & Feb-Nov 1866 \\
$113-144$ & $2(7)$ & $181-212$ & - & Feb-Nov 1866 \\
$145-164$ & $2(9)$ & $257-276$ & $\mathbf{x}[=\mathrm{ii}]$ & Feb-Nov 1866 \\
$165-188$ & $2(10)$ & $277-300$ & ix [=i] & \multicolumn{2}{c}{ Dec 1866 } \\
$189-220$ & $3(1)$ & $1-32$ & - & Jan-Jun 1867 \\
$221-252$ & $3(2)$ & $33-64$ & - & Jan-Jun 1867 \\
$253-254$ & $3(3)$ & $65-66$ & - & Jan-Jun 1867 \\
$255-260$ & $3(3)$ & $91-96$ & Jan-Jun 1867
\end{tabular}


F. A. W. MIQUEL, NETHERLANDS BOTANIST

$\begin{array}{ccccc}\text { pages book } & \begin{array}{c}\text { Annales } \\ \text { vol./pars }\end{array} & \text { Annales pp. } & \text { tt. } & \text { dates Annales } \\ 261-292 & 3(4) & 97-128 & - & \text { Jan-Jun } 1867 \\ 293-324 & 3(5) & 129-160 & - & \text { Jul 1867 } \\ 325-356 & 3(6) & 161-192 & - & \text { Aug-Oct } 1867 \\ 357-373 & 3(7) & 193-209 & - & 21 \text { Nov } 1867 \\ 374-392 & \text { published only in the book itself ("Conspectus florae japonicae"), } \\ \text { i-viii } & \text { 21 Nov 1867. } \\ & \text { published only in the book itself (title-page, dedication to } \\ & \text { Asa Gray and C. I. Maximowicz, introduction, conspectus), } \\ \text { 21 Nov 1867. }\end{array}$

According to the review of part 1 in Flora (48: 540-541 of 15 Nov 1865 the book would be published in four parts. It is not known whether this was actually done. The book is reviewed as a whole in the Bot. Zeitung (25:412413 ) of 20 Dec 1867, and announced as a whole in the Nieusublad voor den Boekhandel of 21 Nov 1867. No further data on contents and dates are, however, available at this moment. It is unlikely that if the book was indeed published in parts, these parts would have preceded publication in the Annales. The dates of the latter can therefore be accepted for the Prolusio.

The text is all by Miquel except that of the Musci frondosi pp. 180-188, 373, which is by C. M. van der Sande Lacoste.

237. Anonaceae archipelagi indici. Ann. Mus. bot. Lugd.-Bat. 2(1): 1-20. t. i. 1865 [Mar], 2(2): 21-45. t. ii. 1865 [Apr-Dec].

238. Myristicaceae. Supplementum. Ann. Mus. bot. Lugd.-Bat. 2(2): 46-51. 1865 [Apr-Dec].

239. Legnotideae archipelagi indici. Ann. Mus. bot. Lugd.-Bat. 2(3): 66-67. 1865 [Apr-Dec].

240. Phoenicosperma, Tiliacearum genus. Ann. Mus. bot. Lugd.-Bat. 2(3): 68. t. iii. 1865 [Apr-Dec].

241. Verslag over den staat van het Rijksherbarium en de aldaar verrigte werkzaamheden gedurende de jaren 1863 en 1864. s.l.n.d. [1865] Oct., dp. 7.

Note: Reprinted with separate pagination from the Staatscourant.

242. Illigereae species archipelagi indici. Ann. Mus. bot. Lugd.-Bat. 2(8): 214-215. 1866 [Feb-Nov].

243. Fagraeae species in archipelago indico et Guinea nova hactenus detectae. Ann. Mus. bot. Lugd.-Bat. 2(8): 216-218. 1866 [Feb-Nov].

244. Verslag over den staat van's Rijks Herbarium te Leiden en de aldaar verrigte werkzaamheden gedurende het jaar 1865. s.l.n.d. Oct., pp. 4.

Note: Reprinted with separate pagination from the Staatscourant. 
245. De Piperaceis Novae Hollandiae. Versl. Med. Kon. Akad. Wet. afd. Natuurk. ser. 2. 2(1): 53-64. 1867.

Date: 21 Feb 1867, announced as available, Nieuwsblad Boekhandel. Reprints of the article (cf. MI 373) are dated 1866.

246. Over de verwantschap der flora van Japan met Azië en NoordAmerika. Versl. Med. Kon. Akad. Wet. afd. Natuurk. ser. 2. 2(1): 65-89. 1867 [on pp. 83-89 "Bijvoegsel, Species novae japonicae"].

Date: According to Merrill and Walker (1938, p. 325) and MI 374 reprints exist with separate pagination and with the date 1866. Part 1 of vol. 2 of the Verslagen was announced as available by the Nieuwsblad voor den Boekhandel on $21 \mathrm{Feb} 1867$.

247. Mantissa Aroidearum indicarum. Ann. Mus. bot. Lugd.-Bat. 3(3): 79-82. t. i-iii. 1867 [Jan-Jun].

248. Annotationes de Dipterocarpeis. Ann. Mus. bot. Lugd.-Bat. 3(3): 83-85. 1867 [Jan-Jun].

249. Observationes de generibus quibusdam indicis. Ann. Mus. bot. Lugd.-Bat. 3(3): 88-90. 1867 [Jan-Jun].

250. Artocarpeae. Ann. Mus. bot. Lugd.-Bat. 3(7): 210-224. 1867 [Aug 1868], 3(8): 225-235. 1867 [Dec 1867-Jul 1868].

251. Chrysobalaneae quaedam indicae. Ann. Mus. bot. Lugd.-Bat. 3(8): 236-237. 1867 [Dec 1867-Jul 1868].

252. Rutacearum quarundam illustratio. Ann. Mus. bot. Lugd.-Bat. 3(8): 242-246. t. 6. 1867 [Dec 1867-Jul 1868].

253. Annotationes de Phytocrenes speciebus archipelagi indici. Ann. Mus. bot. Lugd.-Bat. 3(8): 247-248. 1867 [Dec 1867-Jul 1868].

254. De Nyctocalo et Radermachera, generibus Bignoniacearum. Ann. Mus. bot. Lugd.-Bat. 3(8): 249-250. t. viii. 1867 [Dec 1867Jul 1868].

255. De Clerodendri quibusdam speciebus. Ann. Mus. bot. Lugd.-Bat. 3(8) : 251-254. t. ix. 1867 [Dec 1867-Jul 1868].

256. Annotationes de Ficus speciebus. Ann. Mus. bot. Lugd.-Bat. 3(9): 260-288. 1867 [Dec 1867-Jul 1868], 3(10): 289-300.t. x. 1867 [Aug $1868]$.

257. Sur les affinités de la flore du Japon avec celles de l'Asie et de l'Amérique du Nord. Arch. néerl. Sci. exactes nat. 2(2): 136-156. 1867.-Also published in Adansonia 8: 132-153. Sep-Dec 1867. 
258. Sur le caractère et l'origine de la flore du Japon. Arch. néerl. Sci. exactes nat. 2(4): 289-348. 1867.-Also published in Adansonia 8: 204-263. 25 Feb 1868.

259. Sur les érables du Japon. Arch. néerl. Sci. exactes nat. 2(5) : 467480. 1867.

Date: published in the last fascicle of vol. 2 of the Archives, published towards the end of 1867 or in the beginning of 1868.--Reprints were made with the date 1867. A copy was received by Meissner before 8 Apr 1868 (letter ULU).

Rev.: Bot. Zeitung 26: 351-352. 22 Mai 1868.

A. W. Eichler, Flora $51: 332-333.15$ Aug 1868.

260. Verslag over den staat van 's Rijks Herbarium te Leiden en de aldaar verrigte werkzaamheden gedurende het jaar 1866. s.l.n.d. [1867]. Oct., pp. 4.

Note: reprinted with separate pagination from the Staatscourant.

1868

261. De Palmis archipelagi indici observationes novae. Verh. Kon. Akad. Wet. 11 : 1-33 [sheets 18-22]. t. 1 [col.] 1868.

Date: Feb 1868 [J. D. Hooker acknowledges receipt of a copy on 2 Mar 1868 (letter ULU); Academy copy enscribed 27 Feb 1868; announcement Nieuwsblad Boekhandel 2 Apr 1868, sic.].

Rev.: A. W. Eichler, Flora 51: 316-318. 30 Jul. Bot. Zeitung 26: 846. 4 Dec 1868.

Plate: Lithographed, partly coloured, after drawings by A. Bernecker.

262. De natuurkundige wetenschap in Nederlandsch Indië. De Gids 1868(2): 232-268. Mai 1868, 544-554. Jun 1868.

Note: a partial translation into German was provided by Hasskarl in Flora 1868: 449-464. 1 Nov 1868.

263. Ordo CXCVII. Casuarineae, in Alph. de Candolle, Prodromus systematis naturalis regni vegetabilis $16: 332-344.1868$.

Date: medio Jul 1868. (cf. Stearn).

Ref.: PR 1485.

Stearn, Candollea 8: 1-4. 1939, Journ. of Bot. 79: 25-27. 1941.

264. Nouveaux matériaux pour servir à la connaissance des Cycadées. Première-troisième parties. Arch. néerl. Sci. exactes nat. 3(3): 193-254. Jul-Dec 1868.

Quatrième-cinquième parties. Arch. néerl. Sci. exactes nat. 3(5): 403427. 1868 (or 1869?).

Sixième partie. Arch. néerl. Sci. exactes nat. 5(1): 74-88. 1870.

Also published in Adansonia as follows:

Première partie. Adansonia 8: 359-377. 1 Aug 1868, 9: 29-59. Sep 1868.

Deuxième partie. Adansonia 9: 59-64. Sep 1868.

Troisième partie. Adansonia 9: 64-73. 22 Oct 1868.

Quatrième partie. Adansonia 9: 154-169. 8-9 Mar 1869.

Cinquième partie. Adansonia 9: 169-180. 8-9 Mar 1869.

Sixième partie. Adansonia 9: 352-367. Dec 1870.

Reprints with separate pagination, but without a printed cover, exist of the printing in the Archives. 
265. Over eene monstrositeit der vrucht van Papaver somniferum L. door R. H. C. C. Scheffer, medegedeeld door den Heer F. A. W. Miquel. Versl. Med. Kon. Akad. Wet. afd. Natuurk. ser. 2. 3(1): 86-92. 1868.-reprint pp. [1]-7, t. i. 1868.

Date: 20 Aug 1868, date of announcement part 3(1) in Nieuwsblad voor den Boekhandel.

266. [review of F. W. van Eeden,] De duinen en bosschen van Kennemerland. De Gids 1868(3) : 559-561. Sep 1868.

267. Nog iets over de kina cultuur. De Gids 1868(4): 611-616. Dec 1868.

268. Nieuwe bijdragen tot de kennis der Cycadeen. Eerste-zesde gedeelte. Versl. Med. Kon. Akad. Wet. afd. Natuurk. ser. 2, vols. 3 and 4.

Date: publication took place as follows

$\begin{array}{llcc}\text { Gedeelte } & \text { Vol. Verslagen } & \text { pages } & \text { probable date of publ. } \\ \text { Eerste } & \text { ser. 2. 3(1) } & 1-44 & 20 \text { Aug } 1868 \\ \text { Tweede } & \text { ser. 2. 3(1) } & 45-49 & 20 \text { Aug } 1868 \\ \text { Derde } & \text { ser. 2. 3(1) } & 50-57 & 20 \text { Aug 1868 } \\ \text { Vierde } & \text { ser. 2. 3(2) } & 152-165 & 18 \text { Mar 1869 } \\ \text { Vijfde } & \text { ser. 2. 3(2) } & 196-206 & 18 \text { Mar 1869 } \\ \text { Zesde } & \text { ser. 2. } 4 & 23-37 & 1869 \text { (probably Oct) }\end{array}$

Reprints with separate cover and pagination for 1-3 (pp. 1-57. 1868), 4 (pp. 1-14. 1868), 5 (pp. 1-11. 1868), 6 (not seen, dated 1869). The dates of the reprints point at publication of parts $1-5$ in 1868, 6 in 1869. The reviews of part 6 also point at 1869 as the date of publication; it is probable that reprints were issued: in the summary given by L'Illustration horticole, part 6 is dated Oct 1869. - The dates given above are those on which the relevant parts of the Verslagen were announced as available by the Nieuwsblad voor den Boekhandel. The date for part 6, however, is that of the reprints; the Verslagen ser. 2. 4 (1) were announced by the Nieuwsblad on $29 \mathrm{Jan} 1870$.

Reviews and summaries: L'Illustration horticole 16: 97-101. Nov 1869. Flora 53: 180-183. 24 Mai 1870.

De Bary, Bot. Zeitung 29: 436-437. 1 Jul 1870.

Hamburger Garten u. Blumenzeitung 26: 102-105. 1870.

269. Monographia Meliacearum archipelagi indici. Ann. Mus. bot. Lugd.-Bat. 4(1): 1-32. 1868 [Sep-Dec], 4(2): 33-64. 1868 [Sep-Dec].

270. Ranunculaceae, Magnoliaceae, Dilleniaceae et Menispermeae archipelagi indici. Ann. Mus. bot. Lugd.-Bat. 4(3): 65-88. 1868 [SepDec].

271. Teysmannia Zolling., Palmarum genus. Ann. Mus. bot. Lugd.-Bat. $4(3)$ : 89-90. tt. $i i-i i i .1868$ [Sep-Dec].

272. Filices. Ann. Mus. bot. Lugd.-Bat. 4(3): 91-96. 1868 [Sep-Dec]. 4(4): 97-98. 1869 [21 Feb].

273. Verslag over den staat van's Rijks Herbarium te Leiden, en de aldaar verrigte werkzaamheden gedurende het jaar 1867. s.l.n.d. [1868]. Oct., pp. 4. 
1869

274. Observationes de Zingiberaceis. Ann. Mus. bot. Lugd.-Bat. 4(4): 99-102. 1869 [21 Feb].

275. Adnotationes de Ternstroemiaceis. Ann. Mus. bot. Lugd.-Bat. 4(4): 103-114. 1869 [21 Feb].

276. Combretum arboreum. Ann. Mus. bot. Lugd.-Bat. 4(4): 115. 1869 [21 Feb].

277. De quibusdam Burseraceis et Anacardiaceis. Ann. Mus. bot. Lugd.-Bat. 4(4): 116-118. 1869[21 Feb].

278. De quibusdam Rubiaceis, Apocyneis et Asclepiadeis. Ann. Mus bot. Lugd.-Bat. 4(4): 128. 1869 [21 Feb], 4(5): 129-142. t.v. 1869 [28 Mar].

279. On the sexual organs of the Cycadaceae. Fourn. of Bot. [ed. B. Seemann] 7: 64-78. 1 Mar 1869, 93-105. tt. 91-92. 1 Apr 1869.

Note: "Translated by W. Thiselton-Deyer Esq. B.A. from the author's French edition of the paper published in the Archives neerlandaises t. ii. 1868" (cf. no. 264). - The translator added a number of footnotes.-Reprints were issued (cf. MI 368).

280. Primulaceae archipelagi indici, adjectis observationibus de japonicis. Ann. Mus. bot. Lugd.-Bat. 4(5): 143-147. 1869 [28 Mar].

281. Hippocrateaceae archipelagi indici. Ann. Mus. bot. Lugd.-Bat. 4(5) : 148-154. 1869 [28 Mar].

282. Filices. Ann. Mus. bot. Lugd.-Bat. 4(5): 155-160. 186928 Mar], 4(6) : 161-174. t. vii. 1869 [23 Mai].

283. Bijdragen tot de flora van Japan.

I. Funkia Spr. Versl. Med. Kon. Akad. Wet. afd. Natuurk. ser. 2. 3(3): 295-305. 1869. [communicated 30 Jan 1869], [publ. $29 \mathrm{Jul}]$.

II. Melanthaceën. Versl. Med. Kon. Akad. Wet. afd. Natuurk. ser. 2. 4: 19-22. 1870 [publ. 29 Jan].

III. Valerianeën. Versl. Med. Kon. Akad. Wet. afd. Natuurk. ser. 2. 4: 19-1922. 1870 [publ. 29 Jan].

IV. Salicineën. Versl. Med. Kon. Akad. Wet. afd. Natuurk. ser. 2. 5: 1-6. t. 1. 1871 [publ. 1870 sem. 2?].

Reprints were issued of all four parts; they are provided with a separate pagina tion and a printed cover. The dates in brac kets are those of the announcemen by the Nieuresblad voor den Boekhandel. 
284. Ecloge Rubiacearum archipelagi indici. Ann. Mus. bot. Lugd.-Bat. 4(6) : 179-192. 1869 [23 Mai], 4(7): 193-224. 1869 [8 Jul], 4(8): 2 25-256. 1869 [24 Oct], 4(9): 257-262. 1869 [Nov 1869-Feb 1870].

285. De Cinchonae speciebus quibusdam, adjectis is quae in Java coluntur. Ann. Mus. bot. Lugd.-Bat. 4(9): 263-275. 1869 [Nov 1869-Feb 1870].

Date: Reprints in $\mathrm{Qu}$, with separate pagination, carry the date 1869 (MI 367) (n.v.)

Rev.: De Bary, Bot. Zeitung 29: 323. 8 Apr 1871.

C. Hasskarl, Flora 53: 145-156. 8 Mai 1870.

286. Contribution à la flore du Japon.

I. Funkia. Arch. néerl. Sci. exactes nat. 4(3): 219-230. 1869.

II. Melanthacées. Arch. néerl. Sci. exactes nat. 5(1): 89-92. 1870.

III. Valérianées. Arch. néerl. Sci. exactes nat. 5(1): 93-96. 1870.

Note: cf. Dutch version sub no. 283.-Reprints were issued (MI 366).

287. Verslag over den staat van's Rijks Herbarium te Leiden, en de aldaar verrigte werkzaamheden, gedurende het jaar 1868. s.l.n.d. [1869] Oct. pp. 7. Note: reprinted with separate pagination from the Staatscourant.

288. Veranderingen in de plantenwereld, (een fragment), s.l.n.d., Oct. pp. 22.

Note: Dates from 1869 fide MI 369 but from 1863 fide Matthes 1872 (p. 48). I have not been able to trace the original publication of this pamphlet which is possibly a reprint with separate pagination.

\section{0}

289. Observationes de Urticeis quibusdam et de Fatoua. Ann. Mus. bot. Lugd.-Bat. 4(10): 301-307. t.x. 1869 [Mar 1870].

290. Catalogus musei botanici lugduno-batavi. Pars prima. Flora japonica. Den Haag, Martinus Nijhoff, 1870. Oct. pp. viii, 229.

Publ.: 19 Feb 1870 [ announced as available in Nieuresblad voor den Boekhandel; on 24 Apr 1870 v.d. Sande Lacoste acknowledges receipt of a copy (letter ULU); copies received by University Library Amsterdam, by the Academy Amsterdam, by the Munich library, by the Rotterdam library, all in April fide receipts in archives $L$ but probably sent out only when part 10 of the Annales vol. 4 was available]. 250 copies printed.

Rev.: Flora 53: 266-267. 25 Jul 1870.

Ref.: MI 362, PR 6284.

291. Flora japonica sive plantae, quas in imperio Japonico collegit, descripsit, ex parte in ipsis locis pingendas curavit Dr. Ph. Fr. de Siebold. Regis auspiciis edita. Sectio prima continens plantas ornatui vel usui inservientes. Digessit Dr. J. G. Zuccarini. Volumen secundum, ab auctoribus inchoatum relictum ad finem perduxit F. A. Guil. Miquel.Leiden 1870. Fol. 
Note: pages 1-44 and plates 101-127 were issued by Joseph Gerhard Zuccarini (1797-1848), the rest of vol. 2 was edited by Miquel. Publication took place as follows:

$\begin{array}{clrcc}\text { Volume } & \text { parts } & \text { pages } & \text { plates } & \text { dates } \\ 2 & 1-3 & 1-28 & 101-115 & 1842 \\ & 4-5 & 29-44 & 116-127 & 1844 \\ & 6-10 & 45-89 & 128-150 & 1870\end{array}$

The plates are lithographed, printed in one colour and (in some copies only) partly coloured by hand. The plates of volume 2 are all anonymous.-A photolithographed reprint of reduced size was published in Tokyo, 1934.

Ref.: NI 1842, PR 8675.

Tucker, Fourn. Arnold Arb. 2: 237-239. 1921.

Koidzumi, Acta Geobot. Phytotax. 2: 68-69. 1933.

Nakai, Bot. Mag. Tokyo 40: 361-362. 1926.

Merrill and Walker, Bibl. East As. Bot. 451. 1938.

Stearn in van Steenis-Kruseman, Fl. Males. ser. 1. 4: ccxiii. 1954. Hara, Taxon 4: 47. 1955.

292. Illustrations de la flore de l'Archipel Indien. Amsterdam, C. G. van der Post, Utrecht, C. van der Post Jr., Leipzig, Friedr. Fleischer. 1871. Qu., pp. x, 114, tt. xxxvii.-Préface, pp. v-vi, by W. F. R. Suringar.

Dates: The third part was published by Suringar after Miquel's death: "une vie laborieuse et vouée à la science jusqu'au dernier soupir". According to the preface the plates $20-37$ belonging to the second part were published with the third. However, plates 20-25 were in fact issued with fasc. 2.

$\begin{array}{cccc}\text { Part } & \text { pages } & \text { plates } & \text { dates } \\ 1 & 1-48 & 1-13 & 1870 \\ 2 & 49-96 & 14-25 & 1870 \\ 3 & \mathrm{i}-\mathbf{x}, 97-114 & 26-37 & 1871 \text { (after Jan) }\end{array}$

The book was intended as a simplified continuation of the Annales.

Plates: Uncoloured lithographs after drawings by Ver Huell and Kouwels.

Rev.: Flora 55: 254-255. 1 Jun 1872.

Ref.: MI 361, NI 1385, PR 6285.

Woodward, Catal. Books Brit. Mus. (Nat. Hist.) 3: 1320. 1910. v. Steenis, Fl. males. Bull. 1: 137. 1949.

293. De soorten van het geslacht Cinchona die op Java gekweekt worden. Natuurk. Tijdschr. Ned. Indië 31: 391-409. 1870.

Note: Contains mainly the text of no. 285 , with some of the notes translated into Dutch.

294. Verslag over den staat van 's Rijks Herbarium te Leiden en de aldaar verrigte werkzaamheden, gedurende het jaar 1869, s.l.n.d. [1870]. Oct. pp. 4.

\section{1}

295. Enumeratio piperacearum in Brasilia a Doct. Regnell detectarum, quae nunc in Museo botanico holmiensi asservantur. Versl. Med. Kon. Akad. Wet. afd. Natuurk. ser. 2. 5. 230-238. 1871-also published in Arch. néerl. Sci. exactes nat. 6(2): 168-176. 1871.

296. Verslag over den staat van 's Rijks Herbarium te Leiden en de aldaar verrigte werkzaamheden, gedurende het jaar 1870. s.l.n.d. [1871]. Oct. pp. 4. Note: Dated 20 Jan 1871 [sic, Miquel died on 23 Jan 1871] -reprinted with separate pagination from the Staatscourant. 


\section{APPENDIX I}

\section{The DATES OF PUBLICATION OF THE PARTS of Linnaea CONTAINING ARTIGLES BY MIQUEL}

The problem of determining the dates of publication of the journal Linnaea has been the subject of several articles, summarized by FosTER (1962) and MOORe and WOOD (1965). The latter authors were able to ascertain the dates printed on the original covers of volumes 20-28 and 32-43. Additional information on the dates of publication of the earlier volumes can be obtained from the correspondence between the editor Schlechtendal and one of his most industrious authors, Miquel. No doubt further information will be found in the remaining part of Schlechtendal's correspondence at Halle. As far as Miquel is concerned the following dates are relevant:

\begin{tabular}{|c|c|c|c|c|}
\hline \multirow[b]{2}{*}{ Volume/Heft } & \multicolumn{2}{|c|}{ date on title-page } & \multirow{2}{*}{\multicolumn{2}{|c|}{ actual date }} \\
\hline & pages & of volume & & \\
\hline $11(1)$ & $1-128$ & 1837 & Dec & 1836 \\
\hline $11(2)$ & $129-256$ & 1837 & Mar & 1837 \\
\hline $11(5)$ & $545-608$ & 1837 & Apr- & Dec 1837 \\
\hline $11(6)$ & $609-728$ & 1837 & Aug- & -Dec 1837 \\
\hline $12(1)$ & $1-128$ & 1838 & Mar & 1838 \\
\hline $16(5)$ & $401-512$ & 1842 & Dec & 1842 \\
\hline $17(1)$ & $1-128$ & 1843 & proba & ably Apr-Mai 1843 \\
\hline $17(6)$ & $129-256$ & 1843 & Apr- & Jun 1844 \\
\hline $18(1)$ & $1-112$ & 1844 & $24-26$ & 6 Oct 1844 \\
\hline $18(2)$ & $113-256$ & 1844 & Nov & $1844-F e b \quad 1845$ \\
\hline $18(3)$ & $257-384$ & 1844 & Nov & 1844-Jul 1845 \\
\hline $18(4)$ & $385-512$ & 1844 & Feb- & Aug 1845 \\
\hline $18(5)$ & $513-640$ & 1844 & Mai- & -Dec 1845 \\
\hline $18(6)$ & $641-774$ & 1844 & Jul-D & Dec 1845 \\
\hline $19(1)$ & $1-128$ & 1847 & Jan & 1846 \\
\hline $19(2)$ & $129-256$ & 1847 & Feb & 1846 \\
\hline $19(4)$ & $385-512$ & 1847 & Dec & 1846-Apr 1847 \\
\hline $20(1)$ & $1-128$ & 1847 & Maj & 1847 (cover) \\
\hline $20(2)$ & $129-256$ & 1847 & Jun & 1847 , \\
\hline $20(3)$ & $257-384$ & 1847 & Jul & 1847 \\
\hline $21(4)$ & $385-512$ & 1848 & Aug & $1848\}$ \\
\hline $21(5)$ & $513-640$ & 1848 & Oct & 1848 (cover) \\
\hline $22(1)$ & $1-128$ & 1849 & Mar & 1849 \\
\hline $22(2)$ & $129-256$ & 1849 & Jun & 1849 \\
\hline $22(4)$ & $385-512$ & 1849 & Aug & 1849 \\
\hline $22(5)$ & $513-640$ & 1849 & Sep & 1849 (", \\
\hline $22(7)$ & $769-898$ & 1849 & proba & ably Mai $185^{2}$ \\
\hline $25(5)$ & $513-640$ & 1852 & Jun & 1853 (cover) \\
\hline $25(6)$ & $641-772$ & 1852 & Dec & $1853\}$, \\
\hline $26(2)$ & $129-256$ & 1853 & Apr & $1854\}$ \\
\hline $26(3)$ & $257-384$ & 1853 & Aug & $1854 ?$ \\
\hline
\end{tabular}

Notes: The letters from Schlechtendal to Miquel are at ULU, those from Miquel to Schlechtendal at HAL.

11(1): Hinrich's Verzeichniss 25-31 Dec 1836; Börsenblatt Buchh. 1837: 23. $3 \mathrm{Jan} 1837$.

11(2): S. to M. 29 Dec 36, "being printed", 15 Mar 1837 reprints and Heft ready except for the plate. 
11(6): on p. 645 article dated Jun 1837, p. 650 Jul 1837.

$12(1)$ : S. to M. 4 Feb 1838 "ist jetzt gedruckt", M. to S. 7 Mar 1838, M. in receipt of reprints.

16(5): On p. 512 article dated Sep 1842; M. to S. reprints and Heft sent to M. on 5 Dec 1842.

17(1): "Wird binnen kurzem erscheinen" Linnaea 16, advertisement Mar 1843; S. to M. 12 Apr 1843: article printed, will soon ("sehr bald") be sent.

17(6): On p. 676 article dated Jan 1844; S. to M. 29 Mar 1844 article printed for the greater part; awaits plates, register.

18(1): On p. 50 article dated Mai 1844; Bot. Zeitung rev. 17 Jan 1845; published between 24 and 26 Oct 1844, fide Börsenbl. Buchh. 29 Oct 1844.

18(2): On p. 113 article dated Sep 1844; Adr. Jussieu acknowledges receipt of reprint on 28 Feb 1845 (ULU); rev. Bot. Zeitung 21 Mar 1845.

18(3): On p. 301 article dated Oct 1844.

18(4): On p. 508 seedlist dated Jan 1845; rev. Bot. Zeitung 22 Aug 1845.

18(5): On p. 626 paper dated 1 Mai 1845; rev. Bot. Zeitung 16 Jan 1846.

18(6): On p. 717 paper dated (read) 12 Jun 1845; rev. Bot. Zeitung 16 Jan 1846.

19(1) (2) fide Kuntze, Rev. Gen. 3(2): 158. 1898.

19(4): Although dated Dec 1846 by Kuntze it is possible that this fascicle appeared only in March or April 1847. Schlechtendal sent the fascicle to Miquel on 3 Apr 1847; rev. Bot. Zeitung 5: 355. 14 Mai 1847. Apparently there was an irregularity in the distribution of Hefte 4, 5, and 6.

22(7): Cover not dated, but 21(6) Dec 1849, 23(1) Feb 1850. On 18 Apr 1850 Schlechtendal states that "Heft 7 of 1849" and Heft 2 [sic] of 1850 were not yet ready "durch allerhand Zufälligkeiten". Heft 7 evidently came out with or after 23(2) Mai 1850.

\section{APPENDIX II}

\section{UNPUBLISHED SOURGES}

Archives of the Koninklijke Akademie van Wetenschappen, Amsterdam. File Vrolik on change-over from "Instituut" to "Akademie" 1850-1851.

Archives of the Rijksherbarium Leiden. Files for 1850, 1862-1871.

Letters (17) written by Miquel to Alphonse de Candolle at Geneve between 1847 and 1871, preserved at the Conservatoire botanique, Genève, Switzerland.

Letters (14) written by Miquel to Asa Gray, preserved at the Gray Herbarium of Harvard University, Cambridge, Mass., U.S.A.

Letters (6) written by Miquel to Adrien de Jussieu and to Adolphe Brongniart, preserved at the Laboratoire de Phanérogamie, Muséum d'Histoire naturelle, Paris, France.

Letters (74) written by Miquel to Diederich Franz Leonhard von Schlechtendal at Halle preserved at the University Library of the Martin-Lüther-Universität, Halle, Saale, DDR.-A calendar of the Miquel-Schlechtendal correspondence will be published by me elsewhere.

Letters to Miquel, written by numerous correspondants in the Netherlands and abroad, preserved at the University Library, Utrecht.-Letters addressed to Miquel, quoted in this article are all in this library unless states otherwise. 


\section{NOTES}

1) See Alg. Konst- en Letterbode 1817(1): 37. 17 Jan. 1817.-J. D Hahn (17291785) was professor of medical and natural sciences at Utrecht and Leiden; $M$. W. Schwencke (1707-1785) a physician at the Hague who kept a private botanical garden in which he lectured on botany to surgeons and apothecaries; S. J. van Geuns (1767-1795) was professor of medical and natural sciences at Utrecht (cf. JANSEN en WACHTER 1939-1942).

2) Miquel had four brothers, Franz, Wilhelm, Rudolph, and Johannes. The youngest, Johannes, later achieved fame as one of the progressive members of the German Reichstag. There are still some descendants of A. Th. Miquel living in Germany at present. No descendent of F. A. W. Miquel is known to live in the Netherlands since the death of his daughter Bertha.

3) Willem Vrolik, 1801-1863, professor of anatomy at Groningen (1829-1831) and Amsterdam (1831-1863), son of Gerardus Vrolik (1775-1859) the Amsterdam botanist, zoologist and physiologist; cf. ENGEL 1939, p. 329-330.

4) "Ik houd dit jaar ook wederom de Landhuishoudkunde". Letter van Hall to Miquel, 2 October 1833. - Unless stated otherwise all letters addressed to Miquel cited here are preserved at the University Library, Utrecht.

5). 10 July 1833 “... het schijnt dat zijne persoonlijke overkomst en misschien ook zijn Protestants geloof hem de zege heeft doen wegdragen". The post was that of town physician ("stads doctor") at Naarden.

-) See van Hall's comment in a letter to Miquel dated 13 January 1837.

7) Alg. Konst- en Letterbode 1833(2): 156-159, 172-175.

8) Letter H. C. van Hall to $M$. dated 24 May 1850.

o) Alg. Konst- en Letterbode 1835(2): 1. 3 Jul. 1835.

10) See Alg. Konst- en Letterbode 1831(1): 162. 18 Mar. 1831. C. A. Bergsma had been added temporarily to the Utrecht faculty. In October 1835 Bergsma succeeded $\mathrm{J}$. Kops as ordinary professor in the natural sciences $[$ ibid. 1835(2): 274. 16 Oct. 1835]. The appointments were to the faculty; the professors divided the various disciplines among themselves.

11) The original manuscript is among the Miquel papers at the University Library of Utrecht.

12) The election to the Provinciaal Utrechts Genootschap is reported in the Algemeene Konst- en Letterbode 1838(2): 239; the election as a correspondent of the "Instituut" in that same journal and volume on p. 370 , the award of Blume's works on p. 322, the appointment at Deventer, ibid. 1839(2): 210 ; the election as a member of the Bataafsch Genootschap voor proefondervindelijke Wijsbegeerte at Rotterdam, ibid. $1840(2): 281$.

13) Quirijn Maurits Rudolf Ver Huell collected in the Malay Archipelago between 1815 and 1819 while in the Dutch navy. Many of the drawings made on that trip are at the Rijksherbarium, Leiden (cf. van STEENIS-KRUSEMAN, 1950).

14) See Alg. Konst- en Letterbode 1846(1): 16 for the appointment to the Athenaeum and p. 307 for the appointment to the "Institute". Miquel's memoir to the minister of colonial affairs, Pahud, is mentioned in Bonplandia 3: 115 .

15) In a letter dated 4 July $1846, \mathrm{~J}$. D. Hooker announces the sending of a collection of Hostmann's Surinam plants, the joint present of Mr Bentham and my father to you". Sir William Jackson Hooker and Bentham had sold sets of plants for Hostmann; Miquel received "the remains of what have been paid for and will not sell".

16) Jan Rudolph Thorbecke (1798-1872), liberal statesman, premier 1849-1853, 1862-1866, 1871-1872. As a premier Thorbecke several times occupied the ministry of interior affairs under which fell the Academy of Sciences, the Universities, and the Rijksherbarium at Leiden.

17) Jacob Gijsbertus Samuel van Breda (1788-1867), Dutch botanist and geologist who followed a career at the Universities of Franeker, Gent, and Leiden. In 1839 he became director of the museum of Teyler's Foundation at Haarlem. As a geologist van Breda made a special study of the origin of the Dutch pleistoceine deposits; he was in contact with Cuvier, v. Humboldt and A. P. de Candolle.

18) Julianus Hendrik Molkenboer (1816-1854), physician at Leiden, published on Asiatic Musci as well as on the flora of the Netherlands. Molkenboer was one of the 
founders of the Nederlandsche Botanische Vereeniging; he died during his work on Junghuhn's Melastomataceae. Miquel, who finished the work, dedicated Melastoma molkenboerii to him. (cf. BACKER, 1936, p. 376-377.)

$\left.{ }^{19}\right)$ Jaarb. Kon. Ned. Instituut Wet. Letterk. Schoone Kunsten 1851 : 164-167. 1852 .

$\left.{ }^{20}\right)$ On 26 June 1857 Miquel resigned his membership of the Academy of Sciences on account of a rather formal difference of opinion between himself, then, president, the government, and an academy committee that had been consulted by the government without his knowledge. On 8 May 1860 he was again elected member of the academy. Cf. Jaarb. Kon. Akad. Wet. 1857-1858, and 1860.

21) Winand Carel Hugo Staring (1808-1877), Dutch geologist. Staring had already published a tentative geological map of the Netherlands in 1844. After the dissolution of the committee, Staring finished the work of issuing a geological map (18581867) accompanied by a text in 2 volumes De Bodem van Nederland 1856-1860.

${ }^{22}$ ) Letter to Schlechtendal of 25 July 1855 . The appointment had been made on $20 \mathrm{July,} c f$. Alg. Konst- en Letterbode 67: 229. 21 Jul. 1855.

23) Alg. Konst- en Letterbode 71: 209. 2 Jul. 1859.

24) Alg. Konst- en Letterbode 71: 257. 13 Aug. 1859.

25) See IDENBURG et al. 1927 p. 83 and Utrechtsche Studenten Almanak 1860, p. 100. The numbers given for Utrecht differ slightly in these publications.

$\left.{ }^{26}\right)$ Alg. Konst- en Letterbode 71 : 321 . 8 Oct. 1859.

27) See Handelingen der Tweede Kamer der Staten-Generaal 27ste Zitting, 25 Nov. 1862. 28) The letters written by Teysmann to Miquel between 1846 and 1870 are at ULU. Teysmann consistently signs his name ,J. E. Teijsmann" in these letters; however, the generally accepted spelling Teysmann ( $c f$. e.g. Teysmannia) is preferred here. The correspondence provides much information on this period in the history of the Buitenzorg garden and intriguing side-lights on Cinchona-personalities, and reveals also that it was Miquel who brought the government to reinstate officially the position of Director of the Garden for Scheffer in 1868. Teysmann was "curator" from 1831 until 1869.

\section{REFERENCES}

AGAssiz, L. 1850. Hugh Miller, author of "Old red sandstone" and "Footprints of the Creator". Memoir printed in later editions of $H$. Miller, Footprints of the Creator, here quoted from ed. 11., Edinburgh 1869.

BACKer, C. A. 1936. Verklarend woordenboek der wetenschappelijke namen van de in Nederland en Nederlandsch-Indië in het wild groeiende en in tuinen en parken gekweekte varens en hoogere planten. Groningen/Batavia.

Beijers, J. L. 1871. Catalogue d'une belle collection de livres délaissée par MM. le Dr F. A. W. Miquel, ..., le Dr K. H. B. Hazelhoff Roelfsema, ..., A. Voormolen, ... La vente aura lieu le 29 Avril 1871 . . Utrecht. Blume, C. L. 1850. Antwoord aan den Heer W. H. de Vriese. Allg. Konst- en

- 1850. Opheldering van de inlichtingen van den Heer Fr. Junghuhn. Alg. Konst- en Letterbode 1850(2): 258-261, 274-279. BoER, P. DE. 1866. Specimen botanicum inaugurale de Coniferis Archipelagi

BRYK, O. 1909. Entwicklungsgeschichte der reinen und angewandten Naturwissenschaft im XIX Jahrhundert. Leipzig.

Bijle, H. van DER. 1948. A thenaeum. Winkler Prins Encyclopaedie ed. 5. 2: 586-588.

CAndolle, A.-P.et AlPH. 1824-1869. Prodromus systematis naturalis regni vegetabilis. Paris. 16 vols.

CoHen, E. 1948. Wat leeren ons de archieven omtrent Gerrit Jan Mulder? Verh. Kon. Ned. Akad. Wet. afd. Natuurk. eerste sectie 19(2): 1-73.

Coleman, W. 1964. Georges Cuvier, zoologist. Cambridge, Mass.

Darwin, $C_{H}$. 1859. On the origin of species. London [facsimile reprint Cambridge, Mass. 1964 with an introduction by Ernst Mayr]. 
Engel, H. 1939. Alphabetical list of Dutch zoological cabinets and menageries. Bijdr. Dierkunde 27: 247-346.

Foster, R. C. 1962. Dates of publication of the journal Linnaea. Journ. Arnold Arb. 43: 400-409.

Goddijn, W. A. 1931. 's Rijks Herbarium 1830-1930. Meded. Rijks Herb. Leiden no. 62 .

Gorxom, K. W. van. 1880 - Dr H. C. G. Scheffer en 's Lands Plantentuin te Buitenzorg. [reprinted from Eigen Haard 1880].

1884. De Oost-Indische Cultures in betrekking tot handel en nijverheid. ed. 2. Amsterdam.

1894. Dr Justus Karl Hasskarl. De Indische Mercuur. 13 Jan. 1894. 1896. Kina. Koloniaal Museum Haarlem, ed. 2. Haarlem.

Guillemin, J. B. A. 1837. [Dutch translation of review of C. L. Blume's] Rumphia. Alg. Konst- en Letterbode 1837(1): 89-91, 105-108.

HaLl, H. C. van. 1834. Elementa botanices, in usum lectionum academicarum conscripta. Groningen.

1842. Opmerkingen aangaande een gedeelte van het onderwijs voor aanstaande geneeskundigen. Alg. Konst-en Letterbode 1842(2):210-215.

1842. Nog iets over het onderwijs voor pharmaceuten te Groningen. Alg. Konst- en Letterbode 1842(2): 278.

1852. J. A. Uilkens. De volmaaktheden van den Schepper in zijne schepselen beschouwd, ter verheerlijking van God en tot bevordering van nuttige natuurkennis. Herzien en op de tegenwoordige hoogte der wetenschap gebragt. Vierde deel, behelzende natuurlijke geschiedenis van het plantenrijk. Leeuwarden.

1860. Cornelis Adriaan Bergsma. Utrechtsche Studenten Almanak 1860: 194-205.

Heemskerk BzN, J. 1852. [Review of] G. J. Mulder, Open brief . . . 1851, de Gids $1852(1): 251-262$.

Hutzinga, J. 1914. Geschiedenis der Universiteit gedurende de derde eeuw van haar bestaan 1814-1914. Academia Groningana MDCXIV-MCMXIV. Gedenkboek ter gelegenheid van het derde eeuwfeest der Universiteit te Groningen. Eerste gedeelte. Groningen; here quoted from Verz. Werken 8: 36-339. 1951.

1922. Van Instituut tot Akademie. Jaarb. Kon. Akad. Wet. 1921-1922; also published in Tien Studien 126-155. 1926; here quoted from Verz. Werken 8: 426-449. 1951 .

1922. Denkbeelden en stemmingen van voor honderd jaar.Verz. Werken 4: 392-408.

Idenburg, P. J., F. de Vries en H. van der Bijle. 1927. Van Athenaeum tot Universiteit. Geschiedenis van het Athenaeum illustre in de negentiende eeuw. Amsterdam.

Jansen, P. en W. H. Wachter. Personalia I-V, Ned. Kruidk. Arch. 49: 437-452. 1939 (I) ; 50: 183-205. 1940 (II) ; 51 : 340-379. 1941 (III) ; 52: 371-415. 1942 (IV); 53: 232-257. 1943.

JEssen, K. F. W. 1864. Botanik der Gegenwart und Vorzeit in culturhistorischer Entwicklung. Leipzig [facsimile reprint Waltham, Mass. 1948].

JunghunN, F. 1850. Inlichtingen aangeboden aan het publiek over zeker geschrift van den Heer C. L. Blume, en antwoord aan dien Heer. Alg. Konst- en Letterbode $1850(2): 232-240$.

Junghuhn, F. R. en W. H. DE VRIESE. 1848. 1851. Kritiek en antikritiek. Een woord over den boom Sambinoer op Sumatra betrekkelijk deszelfs botanische bepaling volgens C. L. Blume. Ned. Kruidk. Arch. 1: 261 (1848), 2: 16 [add.] (1851).

Kerbosch, M. 1948. De Kinacultuur, in C. J. J. van Hall en C. van den Koppel, De landbouw in de Indische Archipel 24: 747-865.

Kibell, W. X. F. von. 1871. Dr Friedrich Anton Miquel. Sitzungsber, math.-phys. cl. Akad. Wiss. München 1: 151-153.

LABRUYère, W. 1938. G. J. Mulder, thesis, Leiden.

Lask̇gue, A. 1845, Musée botanique de M. Benjamin Delessert. Paris.

Martius, K. F. P. von et al. 1840-1906. Flora brasiliensis. München, 15 vols. 
Matrhes, C. J. 1872. Levensbericht van F. A. W. Miquel. Jaarb. Kon. Akad. Wet. Amsterdam 1872: 29-49.

MERRILL, E. D. and E. H. WALKER. 1938. A bibliography of eastern Asiatic botany. Jamaica Plain.

Miller, H. 1849. Footprints of the Creator. London. [ed. 1, n.v.; cited from ed. 11, $1869]$.

Moens, J. C. B. 1882 . De Kinacultuur in Azië 1854 t/m 1882. Batavia.

MoORE, H. E., JR. and C. E. Wood, JR. 1965. Dates of publication of the journal Linnaea: further evidence. Journ. Arnold Arb. 46: 68-73.

Mulder, G. J. 1851. Open brief aan den Heer Mr. J. R. Thorbecke, Minister van Binnenlandsche Zaken, lid van het Koninklijk Nederlandsch Instituut. Rotterdam.

1872. Herinneringen omtrent F. A. W. Miquel. Utrechtsche Studenten Almanak 1876: 157-213.

Muller, F. K. 1902. Geschichte der organischen Naturwissenschaften im neunzehnten Jahrhundert. Berlin.

Nissen, G. 1951. Die botanische Buch-Illustration. 2 vols. Stuttgart.

Nolet de Brauwere van SteEnland, J. 1851. Het Koninklijk Nederlandsch Instituut R.I.P. - cf. anon. review in Alg. Konst- en Letterbode 1851 (2): 364-365.

Oudemans, C. A. J. A. 1877. [obituary notice of H. C. van Hall in] Ned. Kruidk. Arch. ser. 2. 2: 17-21.

1877. De ontwikkeling onzer kennis aangaande de flora van Nederland. Ned. Kruidk. Arch. ser. 2. 2: 214-277.

Pluche, N.-A. 1732-1737. Le spectacle de la nature, ou entretiens sur les particularités de l'histoire naturelle, etc. 9 vols., Paris.

Pritzel, G. A. 1872-1877. Thesaurus literaturae botanicae ed. 2. Leipzig.

Pulle, A. A. 1906. An enumeration of the vascular plants known from Surinam, together with their distribution and synonymy.

1938. De inventarisatie van het erfdeel der vaderen. Meded. Bot. Mus. Utrecht 50.

ReHDER, A. 1911-1918. The Bradley bibliography 5 vols. Cambridge, Mass.

SACHs, J. vos. 1892. Histoire de la botanique du XVIe siècle à 1860 . Paris.

SIRKs, M.J. 1918. Friedrich Anton Wilhelm Miquel. Nieuw Nederl. Biogr. Woordenboek 4: 986-987.

. 1915. Indisch natuuronderzoek. Thesis, Utrecht.

Stafleu, F. A. 1963. Adanson and the "Familles des plantes", Adanson $1: 123-264$.

Standley, P. C. 1936. Flora of Peru, Publ. Field Mus. Nat. Hist. Chicago Bot. Ser. $13(6)$.

SteEnts-KrUSEMAN, M.J. van. 1950. Malaysian plant collectors and collections. Flora Malesiana ser. 1., vol. 1 .

Suringar, W. F. R. 1872. Verslag over den staat van 's Rijks Herbarium te Leiden, gedurende het jaar 1871 (reprinted from the "Staatscourant").

Thorbecke, J. R. 1867. Parlementaire redevoeringen. Ministerie van Februarij 1862 tot September 1863. Deventer.

Uilkens, J. A. 1801-1802. De volmaaktheden van den Schepper in zijne schepselen beschouwd, tot verheerlijking van God en tot bevordering van nuttige natuurkennis in redevoeringen. Groningen, 5 vols. For the revised edition of 1852-1855, see van Hall 1852 and Miquel 1855 (no. 168).

URBAN, J. 1906. Miquel, Fridericus Antonius Guilielmus (1811-1871). Flora brasiliensis 1(1): 189-190. 1906.

Valckenier Suringar, J. 1903. Het Melocactus onderzoek. Ned. Kruidk. Arch. ser. 3. 2: 1047-1058.

WoOdWARD, B. B. et al. 1903-1940. Catalogue of the books, manuscripts, maps and drawings in the British Museum (Natural History). 8 vols., London. 